\title{
BEYOND THE BOUNDARIES OF THE CAROLINGIAN CLOISTER: AN EXAMINATION OF MONASTIC INTERACTION DURING THE EARLY NINTH CENTURY
}

BY

CORINNA J. PRIOR, B.A.

A THESIS SUBMITTED TO THE FACULTY OF GRADUATE STUDIES AND RESEARCH IN PARTIAL FULFILLMENT OF THE REQUIREMENTS FOR THE DEGREE OF

MASTER OF ARTS

DEPARTMENT OF HISTORY

\author{
CARLETON UNIVERSITY \\ OTTAWA, ONTARIO \\ AUGUST 10, 2009
}

(C) COPYRIGHT 2009, CORINNA J. PRIOR 


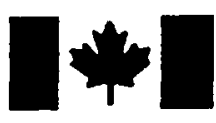

Library and Archives
Canada

Published Heritage

Branch

395 Wellington Street

Ottawa ON K1A ON4

Canada
Bibliothèque et

Archives Canada

Direction du

Patrimoine de l'édition

395, rue Wellington

Ottawa ON K1A ON4

Canada

Your file Votre refférence

ISBN: 978-0-494-58433-0

Our file Notre reférence

ISBN: $978-0-494-58433-0$

NOTICE:

The author has granted a nonexclusive license allowing Library and Archives Canada to reproduce, publish, archive, preserve, conserve, communicate to the public by telecommunication or on the Internet, loan, distribute and sell theses worldwide, for commercial or noncommercial purposes, in microform, paper, electronic and/or any other formats.

The author retains copyright ownership and moral rights in this thesis. Neither the thesis nor substantial extracts from it may be printed or otherwise reproduced without the author's permission.
AVIS:

L'auteur a accordé une licence non exclusive permettant à la Bibliothèque et Archives Canada de reproduire, publier, archiver, sauvegarder, conserver, transmettre au public par télécommunication ou par l'Internet, prêter, distribuer et vendre des thèses partout dans le monde, à des fins commerciales ou autres, sur support microforme, papier, électronique et/ou autres formats.

L'auteur conserve la propriété du droit d'auteur et des droits moraux qui protège cette thèse. $\mathrm{Ni}$ la thèse ni des extraits substantiels de celle-ci ne doivent être imprimés ou autrement reproduits sans son autorisation.
In compliance with the Canadian Privacy Act some supporting forms may have been removed from this thesis.

While these forms may be included in the document page count, their removal does not represent any loss of content from the thesis.
Conformément à la loi canadienne sur la protection de la vie privée, quelques formulaires secondaires ont été enlevés de cette thèse.

Bien que ces formulaires aient inclus dans la pagination, il n'y aura aucun contenu manquant.

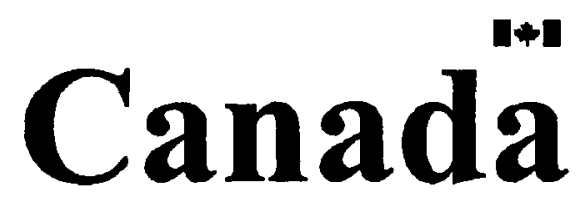




\begin{abstract}
This thesis examines interaction between early ninth-century monks and the world outside the cloister in Carolingian Europe. Although the manners in which monastic authors regulate this contact remained diverse, many underscored desire to both invite guests within monastic walls or else to travel within the surrounding community to assist, teach, or establish new monasteries. Instead of threatening monastic claustration, authors often framed interaction as a means to further monks' spiritual development. I approach early ninth-century monastic writing on interaction by genre, considering capitulary texts, a commentary on the Benedictine Rule by Smaragdus of Saint Mihiel, and hagiographic narratives. Within each of these genres, monastic authors constructed different forms of physical and mental boundaries between the monastery and the outside world. These boundaries did not serve to prevent anyone from entering or exiting the monastery, but rather heightened the power of a sacred space by drawing attention to the transition.
\end{abstract}




\section{ACKNOWLEDGEMENTS}

Many people helped me in the course of writing this thesis and I am grateful to all for their continued support and advice. Above all I would like to thank Dr. Marc Saurette whose passion for the study of monasticism inspired my own. Without his playful spirit, patient teaching, and engaging debate, I could not have conceived of or completed this project and I am forever in his debt. I am no less thankful to the two other professors who made up my thesis committee-Dr. Robin Norris and Dr. Paul Nelles. Dr. Norris has been a wonderful mentor both by introducing me to Anglo-Saxon studies and by ceaselessly encouraging me in my academic career, while Dr. Nelles' sharp eye and critical suggestions were invaluable to me.

I would like to extend gratitude to everyone within the Department of History at Carleton University. In particular, Dr. Dominique Marshall has spent countless hours assisting me in writing grant proposals and has taken an active interest in my scholarship throughout the past two years. As well, I could not have completed this thesis without the assistance of Joan White, who always found time to help me locate grants, employment, and understand departmental regulations despite having to deal with a never ending raft of paperwork.

I am equally fortunate to have had the support of my friends and family. Discussions with Julie Tracz, Ward Minnis, and Colin Grittner provided me with a wonderful forum for discussion and acted as a support group throughout the long writing process. I owe an equal amount of gratitude to the entire Plunkett-Latimer family, who kindly housed and nourished me throughout the past year when my budget was particularly tight. Thanks also to my sister, Kayla Prior, for having always been ready to distract me from writing when I needed a break, and to Dave Rowat, for having encouraged and assisted me like a brother for many years.

This thesis would not have been possible if it were not for my mother, Elley Prior, who taught me the importance of education throughout my childhood and who spent countless hours this past year helping me edit and providing emotional support. Finally, I must make particular mention of Abraham Plunkett-Latimer, whose words and ideas are woven within the text of this thesis. Beyond his academic support, his goluptious discussions of snoods and penguins continue to give me the strength and a desire to learn and play with ideas. 
TABLE OF CONTENTS

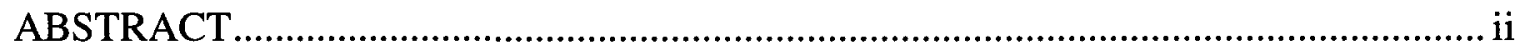

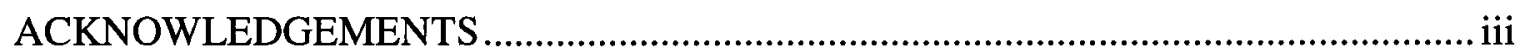

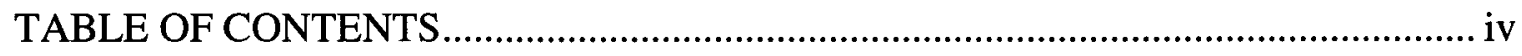

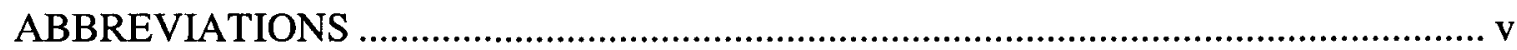

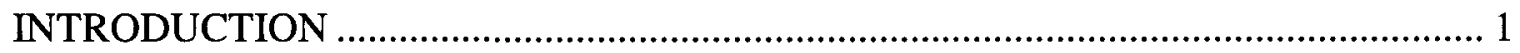

BEYOND REFORM: RECONSIDERING CAROLINGIAN MONASTICISM AND

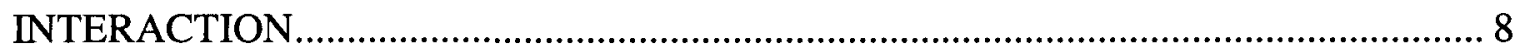

INTERACTION THROUGH THE RECEPTION OF GUESTS IN AACHEN

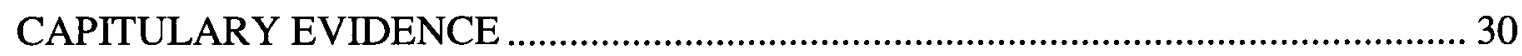

INTERIOR CLAUSTRATION AND ACTIVE HOSPITALITY IN SMARAGDUS' EXPOSITIO IN REGULAM SANCTI BENEDICTI .

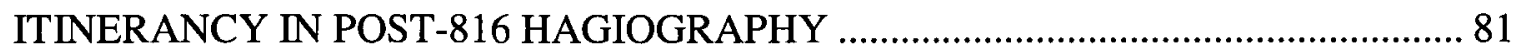

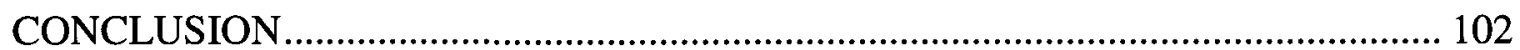

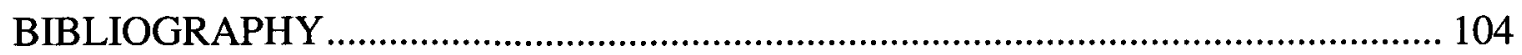


Acta Praeliminaria

CCCM

$C C M$

Expositio

Dionysio-Hadriana

$M G H$

Cap

SS

$S R G$

$E S$

$P L$

Primae decreta

$R B$

Statuta Murbacensia

Secundae decreta

\section{ABBREVIATIONS}

Synodi primae Aquisgranensis acta praeliminaria, ed. Josef Semmer, CCM 1 (Sieburg: 1963), 433-436.

Corpus Christianorum Continuatio Mediaevalis (Turnhout: 1966-).

Corpus consuetudinum monasticarum, ed. K. Hallinger (Sieburg: 1963-).

Smaragdus of Saint Mihiel, Expositio in regulam sancti Benedicti, CCM 8, eds. Alfred Spannagel and Pius Engelbert (Sieburg: 1974).

Dionysio-Hadriana, PL 67, ed. J.-P. Migne.

Monumenta Germanicae Historica

Capitularia regum Francorum, ed. Alfred Boretius, 2 vols. (Hanover: 1883).

Scriptores 2, ed. George Pertz (Hanover: 1829).

Scriptores rerum Germanicarum in usum scholarum separatism editi, ed. Alfred Boretius (Hanover: 1883).

Epistolae Selectae 1, ed. Michael Tangl (Berlin: 1916)

Patrologia Cursus Completus, Series Latina, ed. J.-P. Migne, 221 vols. (Paris: 1841-1864).

Synodi primae Aquisgranensis decreta authentica 816, ed. Josef Semmler, CCM 1 (Sieburg: 1963), 451-468.

Regula sancti Benedicti, in RB 1980, ed. Timothy Fry (Collegeville: Liturgical Press, 1981).

Actuum Praeliminarius Synodi Primae Aquisgranensis Commentationes Sive Statuta Murbacensia 816, ed. Josef Semmler, CCM 1 (Sieburg: 1963), 437-450.

Synodi secundae Aquisgranensis decreta authentica 817 , ed. Josef Semmler, CCM 1 (Sieburg: 1963), 469-481. 
Vita Adalhardi

Vita Benedicti Anianensis

Vita Sturmi
Paschasius Radbertus, Vita sancti Adalhardi, PL 120, ed. J.-P. Migne, cols. 1507-1556.

Ardo of Aniane, Vita sancti Benedicti Anianensis, PL 103, ed. J.-P. Migne, cols. 0351B-0384C.

Eigil, Vita sancti Sturmi, MGH SS 2, ed.George Pertz (Hanover: 1829), 365-377. 


\section{INTRODUCTION}

At the request of abbot Gozbert during the early 820 s, an anonymous artist sketched and notated a floorplan to aid in the reconstruction of the monastery of Saint Gall. Far from depicting the monastery as a site of quiet solace, the artist presents a church and cloister at the centre of an expansive network of buildings. Workhouses and mills which monks and laymen jointly operate extend beyond the northern side of the cloister, and corrals of livestock along with their attendants occupy the western edge of the Plan. Flanking both sides of the entrance to the church are an aristocratic guesthouse, school, and a residence for pilgrims and laymen, while rooms for visiting monks form part of the northern wall of the church itself. ${ }^{1}$ Although only certain components of this Plan were ever built, the artist's conception of the monastery alone reveals that he understood the opus Dei as more than prayer and contemplation. His monastery was also a hub for social interaction between the monks of Saint Gall and other sacred and secular visitors.

The artist of the Plan identifies a complex relationship between the resident monks and their guests through his placement of monastic structures. In one sense, he demarcates firm boundaries between the central cloister of the monks and the periphery lodgings of guests. By crafting the cloister as the focal point of the Plan, the artist intends the visitors to gaze upon the monks, thereby establishing a relationship in which visitors honour the monks of Saint Gall by observing them. He reverses this relationship in the refectory by placing the guests' table in the centre of the building, directly in front 2009).

\footnotetext{
${ }^{1}$ Plan of Saint Gall, St. Gall Monastery Plan, http://www.stgallplan.org/ (Accessed on August 10,
} 


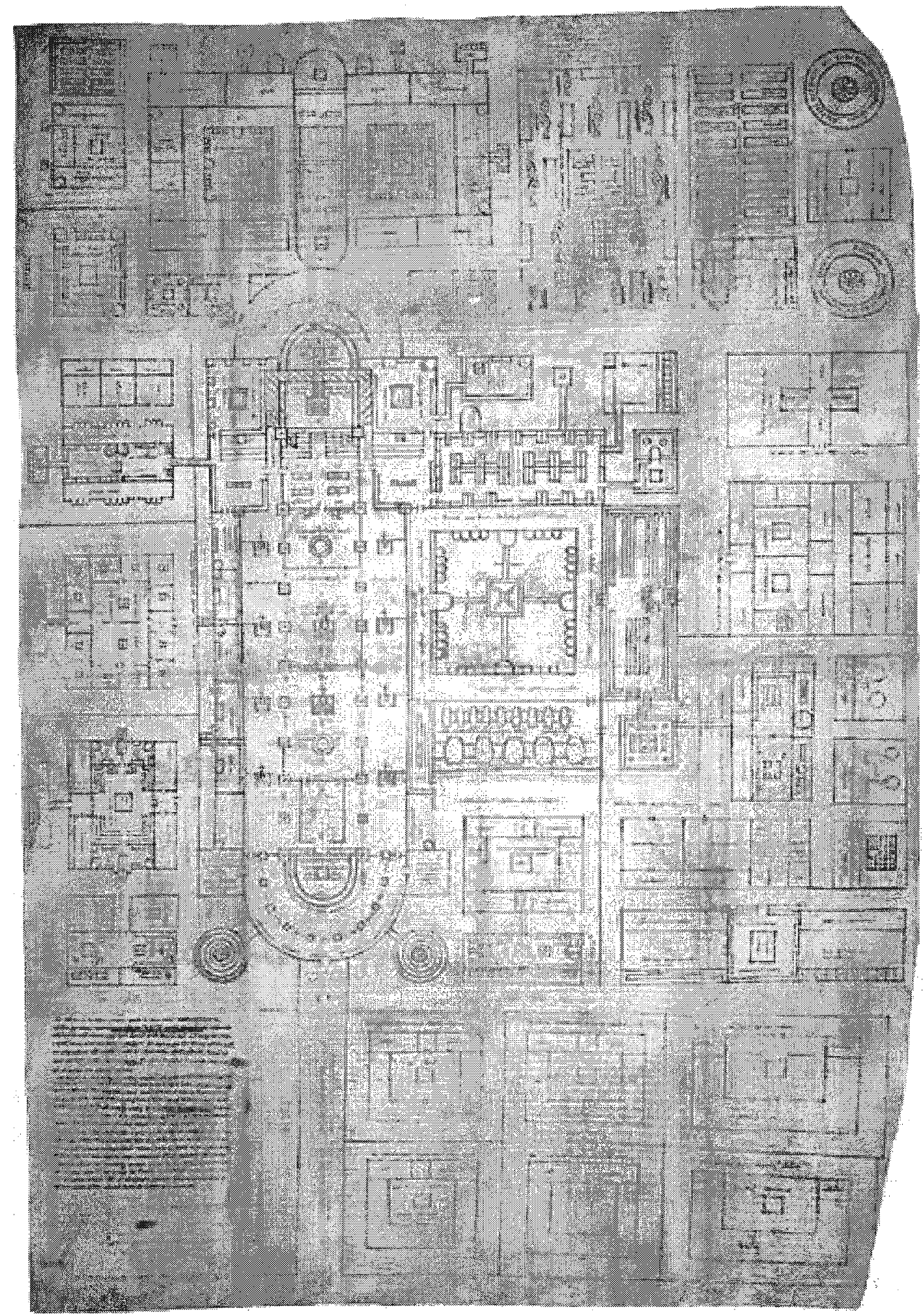

Figure 1. Plan of Saint Gall, St. Gall Monastery Plan, http://www.stgallplan.org/ (Accessed on August 10, 2009). Although there is no indication on the document itself, north is most likely the left side of the Plan as the alter of Carolingian churches typically face east. 
of the reader's pulpit and surrounded by the tables of the resident monks. ${ }^{2}$ During meals, therefore, the monks' seating arrangement was such that monks would honour their visitors by gazing upon them. Inverting the gaze of the two groups suggests that both parties desired contact with one another and their interaction was of mutual benefit.

The artist further underscores the intimacy between the visitors and the resident monks by constructing a room between the church and the cloister where monks and their visitors may speak with one another. In between the etched outlines of this room's walls, the artist notes in a minuscule hand that it is the "exit and entrance to the cloister where the monks may engage in conversation with the guests and where the washing of feet takes place." ${ }^{3}$ As the cloister is both central to the design of this Plan and to the monks' way of life, placing this meeting room on the threshold signifies the importance of contact to the artist. Incorporated within the very walls of the cloister, interaction with visitors to the monastery becomes not only desired, but a central part of monastic life. Unlike the artist behind the Plan of Saint Gall, modern scholars of ninth-century monasticism have been reluctant to acknowledge the importance of interaction between monks and members of the outside world. Relying on a series of capitulary texts produced at the palace of Aachen during 816 and 817, they assert that these documents

\footnotetext{
${ }^{2}$ This table is separate from the abbot's table, which is on the eastern side of the refectory. Thus, it is not merely that the guests share the abbot's table in a position of power. The inclusion of a separate table for guests varies from the Aachen capitularies, which suggests that guests ought to share a table with the abbot.

${ }^{3}$ Plan of Saint Gall, St. Gall Monastery Plan, http://www.stgallplan.org/StGallDB/plan_components/public_list_berschin_english (Accessed on August 10, 2009): "exitus et introitus ante claustrum ad conloquendum cum hospitibus et ad mandatum faciendum." $R B$ indicates that the washing of the feet is one of the first rituals performed when guests arrive at the monastery, suggesting that this may be the first room in which the resident monks and guests meet. If this were the case, the placement of the room would hold even more significance, as the initial reception would take place so near the cloister itself. See $R B$, chapter 53, 256-259: "Aquam in manibus abbas hospitibus det; pedes hospitibus omnibus tam abbas quam cuncta congregatio lavet."
} 
imposed universal adherence to Regula Benedicti and emphasized strict claustration.

These historians have concluded that Carolingian monks desired to sever contact with those who dwelled outside the walls of their houses. ${ }^{4}$ When confronted by sources such as the Plan of Saint Gall, however, historians have explained away this inconsistency by framing the text as deviant. ${ }^{5}$

The purpose of this thesis is to explore this issue, by examining closely how early ninth-century monks recorded and described their interaction with the world outside the cloister in the decade following the Aachen reform councils. The central manner in which these monks pursued contact with the outside world was through face-to-face meetings, both receiving outsiders within the cloister and by travelling beyond the walls of their monasteries. My research suggests that instead of a single homogenous attitude, monks demonstrated a multiplicity of ideas and customs surrounding interaction in the time immediately, as well as long after, the $816 / 817$ capitulary texts. I argue that contact between monks and outsiders was an important component of claustration, both desired and sought after.

In order to demonstrate that monastic writing incorporated and encouraged interaction in multifarious manners, I analyze three different genres of texts prevalent in

\footnotetext{
${ }^{4}$ Some influential studies that suggest there was a growing interest in claustration during the late eighth and early ninth century that led to a desire for less contact with the outside world include Mayke de Jong, "Imitatio Morum. The Cloister and Clerical Purity in the Carolingian World," in Medieval Purity and Piety. ed. Michael Frassetto (New York: Garland Publishing, 1998), 49-80; de Jong, "Carolingian Monasticism: The Power of Prayer," vol. 2 of New Cambridge Medieval History, c. 700-900, ed. Rosamond McKitterick (Cambridge: Cambridge University Press, 1995), 622-653; Maribel Dietz, Wandering Monks, Virgins, and Pilgrims: Ascetic Travel in the Mediterranean World, A.D. 300-800 (Pennsylvania: Pennsylvania State University Press, 2005); Walter Horn, "On the Origins of the Medieval Cloister," Gesta 12, no. 1 (1973): 13-52; and Paul Mayvaert, "The Medieval Monastic Claustrum," Gesta 12 , no. 1 (1973): 53-59.

${ }^{5}$ I discuss this framing of monastic sources further as either reflecting ideals or deviant practices in chapter one. See chapter one, 17-20.
} 
the early ninth century: legislative material, as typified by the Aachen capitulary texts, commentaries on monastic rules, such as Smaragdus of Saint Mihiel's Expositio in regulam sancti Benedicti, and hagiographic texts. A historiographic focus on capitulary sources has led to problematic interpretations of ninth-century writing, as scholars overly dichotomize texts either as perpetuating the Aachen ideal, or else demonstrating deviant practice of unaccepted monastic customs. This characterization distorts the heterogeneity of monastic writing and disregards the variety of monastic customs which monks continued to practice in the ninth century.

My first chapter explores the historiography surrounding monasticism and claustration during the eighth and ninth centuries, and suggests that many historians have focused exclusively on the study of monastic capitularies as the defining source for Carolingian monasticism. Interpreting the capitulary sources as evidence for the problematic claim that western Europe underwent an intellectual and cultural renaissance during the Carolingian period, scholars often incorrectly conclude that the capitulary texts absolutely standardized monastic practice and ideology in the ninth century. The result of this concentration on a single genre of monastic writing has led to a distorted picture of the Carolingian monastic program, positing in particular that monks desired to sever contact with the world beyond the walls of the cloister.

Following my examination of the scholarship, my second chapter examines the manner in which the Aachen capitulary texts of 816 and 817 present contact between monks and outsiders. I suggest that the capitularies present a distinct monastic program that emphasizes the regulation of a monk's physical actions and behaviours.

Highlighting the cloister as the boundary between sacred and secular space, I demonstrate 
that the capitularies encourage contact with outsiders through the reception of guests within the monastery. This approach continues to celebrate interaction, while highlighting the importance for monks to remain within their cloisters.

Chapters three and four seek to explore the presentation of interaction within genres of monastic writing other than the capitulary sources. I first consider Smaragdus of Saint Mihiel's Expositio in regulam sancti Benedicti, a lengthy commentary on $R B$ which underscores the importance of the interiority of Carolingian monks. Presenting a monastic program that emphasizes interior claustration, Smaragdus suggests that the physical cloister is less important to the construction of monastic space. As he directs more attention to occupying a monastic state of mind rather than a physical monastery, Smaragdus is more tolerant of itinerancy and particularly encourages active reception of guests.

Finally, chapter four compares the presentation of interaction within three monastic vitae which were written in the decade following the production of the Aachen capitularies. Unlike the Aachen reform texts and Smaragdus' Expositio, these vitae encourage itinerancy as the primary manner in which monks ought to interact with outsiders. Depicting monks and abbots frequently journeying outside the cloister, the authors of these three texts highlight the educational, spiritual, and miraculous benefits which itinerancy provides. The terminology that each author employs to describe journeys and the purposes behind these journeys varies, suggesting that monastic customs and ideologies continued to differ throughout the Carolingian period.

By examining the fluid attitudes toward interaction between monks and outsiders within these three ninth-century genres of monastic writing, I demonstrate that the 
Aachen capitulary texts did not transform Carolingian monasticism into a homogeneous institution. Rather, they present one set of customs which other monastic authors challenged and modified. Although they each suggest that monks interacted with outsiders for different reasons, all of these monastic authors encouraged the practice and did not interpret contact as a threat to claustration, but as a beneficial activity which aided monks and was part of the opus Dei. 


\section{CHAPTER ONE}

\section{BEYOND REFORM: RECONSIDERING CAROLINGIAN MONASTICISM AND INTERACTION}

The monastic legislation from Aachen of Emperor Louis the Pious is both the height and peak of the ancient development of Benedictine monasticism. Benedict of Aniane, for whom the records offer the name of Benedict II, established the Rule of Saint Benedict [of Nursia] as the only standard of living for monks. Assembling the important points of the Rule, he modified monastic traditions in the kingdom of the Franks and in Italy. ${ }^{1}$

In the Latin introduction to the 1963 edition of the four Carolingian monastic capitularies of 816 and 817, Josef Semmler frames the texts as legislative documents that both transformed and unified Carolingian monasticism throughout the empire. ${ }^{2}$ Implying that earlier monastic traditions were both variable and disorganized, he suggests that the Carolingian emperor, Louis the Pious, directly implemented a new monastic program with the assistance of abbot Benedict of Aniane. Referring to the production of these documents as the "Aachen reforms", Semmler asserts that the capitularies were the very definition of Carolingian monasticism. His emphasis upon the Aachen capitulary texts

\footnotetext{
'Josef Semmler, ed., "Introductio," Legislatio Aquisgranensis, CCM 1 (Sieburg: 1963), 425: "Aquisgranensis legislatio Ludovici Pii imperatoris monastica et culmen et cardo est priscae Benedictinae rei evolutionis. Benedictus enim Anianensis, cui monumenta nomen praebent Benedicti II, Regulam s. Benedicti unicam vivendi normam monachis constituit traditionesque monasticas in Francorum regno Italiaque pollentes colligens s. Benedicti Regulae adaptavit." All translations from Semmler's edition are my own.

${ }^{2}$ This edition comprises of nine monastic capitulary texts which Semmler collectively entitles the Legislatio Aquisgranensis. The most relevant capitulary texts in the context of this thesis are the Synodi Primae Aquisgranensis Acta Praeliminaria, Actuum Praeliminarius Synodi Primae Aquisgranensis Commentationes sive Statuta Murbachensis, Synodi Primae Aquisgranensis Decreta Authentica, and Synodi Secundae Aquisgranensis Decreta Authentica. Though Semmler has gathered these documents together in the $C C M$, there is no surviving manuscript which contains all the documents together. Rather, these four capitularies are spread across fourteen widely dated codices. Furthermore, while previous editions of parts of these documents do exist, Semmler is the first scholar who separates these capitularies from other diplomatic sources on non-monastic subjects. See Semmler, ed., Legislatio Aquisgranensis, CCM 1 (Sieburg: 1963), 423-582. I discuss this edition and the four capitulary texts further in chapter two, 30-57.
} 
has greatly influenced subsequent scholarship, which is problematic, as he makes many assumptions about the intentions, authors, and impact of the reform using little evidence beyond the capitularies themselves.

Using the capitularies to support claims of renewed monarchical power during the Carolingian reign, historians have constructed a dichotomous relationship between the Aachen ideals and deviant practices of monasticism throughout the early ninth century. I argue that this framework has skewed our understanding of the relationship between monastic texts, and undermines the fluidity of ideologies and customs that monks continued to express in different genres of monastic writing. As the capitulary texts articulate an augmented interest in the cloister, their dominance within the field of Carolingian monasticism has misled scholars into asserting that monks desired to sever contact with the outside world. In order to examine these historiographic trends, I first consider scholarship pertaining to Carolingian monasticism and ninth-century reform, and then turn to research focusing on the shift in attitudes toward claustration during the late antique and Carolingian periods.

\section{DECONSTRUCTING CONCEPTIONS OF CAROLINGIAN MONASTIC REFORM}

Twentieth-century historians have typically studied early ninth-century monasticism as a means to support the claim that western Europe underwent a wide cultural and institutional renaissance during the Carolingian period. In order to buttress this claim, they point to a number of monastic capitulary texts which lay out a series of regulations and customs that they take as evidence for eighth and ninth-century monasticism engaging with this spirit of reform and renewal. Scholarship on Carolingian 
monasticism has consequently overemphasized the presence of reform ideology and limited research to three major paths: the impact of single system-wide reformers, the determining influence of capitulary texts, and the dichotomous presentation of all other monastic texts as either pro-reform or anti-reform.

In line with the penchant of twentieth-century political history to focus on grand era-defining figures, historians often portray Carolingian emperors as central to the narrative of reform. In particular, they concentrate on Charlemagne, whom scholars largely credit with having brought about a cultural, intellectual, and institutional renaissance from the remnants of an otherwise dark, murky, and fragmented Merovingian reign. ${ }^{3}$ Until more recently, scholars viewed Charlemagne's son, Louis the Pious, as a failing successor who was tainted with the shame of having soiled his father's otherwise magnificent empire. This portrayal of Louis, however, problematically serves to further glorify Charlemagne's success by emphasizing his son's failures.

The negative characterization of Louis has had an adverse impact on the study of ninth-century monasticism; scholars suggest that it was the emperor's overly proponent attitude toward the exclusive reform of sacred institutions and practices which led to the downfall of the Carolingian empire. Émile Amann well illustrates this trend, into which Arthur Kleinclausz, Ferdinand Lot, and Louis Halphen also fall, when he notes

\footnotetext{
${ }^{3}$ The most relevant studies which use the capitulary texts in order to support the thesis of a Carolingian renaissance include Jean Chélini, L'Aube du Moyen Âge, naissance de la chrétienté occidentale : la vie religieuse des lä̈cs dans l'Europe carolingienne (750-900) (Paris: Picard, 1991); Carlo de Clercq, La Législation religieuse franque de Clovis à Charlemagne. Étude sur les actes de conciles et les capitulaires, les statuts diocésains et les règles monastiques, 507-814 (Louvain: Bureau du recueil, 1936); Eric Waldram Kemp, "The Carolingian Reforms. Episcopal Canonization From the Ninth to the Twelfth Centuries," in Canonization and Authority in the Western Church (London: Oxford University Press, 1948), 36-55; Donald Bullough, "Euopae Pater: Charlemagne and his Achievement in the Light of Recent Scholarship" in English Historical Review, 75 (1970): 59-105; J.M. Wallace-Hadrill, The Frankish Church (Oxford: Oxford University Press, 1983); Pierre Riché, The Carolingians: A Family who Forged Europe, trans. Michael Allen (Philadelphia: University of Pennsylvania Press, 1993); Roger Collins, Charlemagne (London: Palgrave, 1998).
} 
pejoratively, "Charlemagne had the piety of a lay person... Louis, the devotion of a priest or a monk."4 This portrait of Louis emphasizes excessive devotion, which Amann contrasts with Charlemagne's more proper level of piety; Louis' excesses meant he was distracted from the concerns of empire and instead enraptured with "the reform of the church, and most certainly the reform of the monastic state." 5 This picture of Louis as an obsessive monastic addict becomes the central slander which Amann utilizes to emphasize his ultimate failure as emperor in comparison to Charlemagne. ${ }^{6}$

Thomas Noble challenges this portrayal of Louis. He asserts that scholars traditionally attack Louis on three issues-he was not as successful as his father, he had a weak character, and he was subservient to the clergy. ${ }^{7}$ He recasts Louis in a positive light by suggesting that the emperor concentrated on monastic reform because he found the structure of a monastery to be an effective model upon which he might organize his empire. $^{8}$ However, though this reframing challenges the traditional negative view of Louis the Pious, Noble simply replaces one 'great man' narrative with another. He

${ }^{4}$ Émile Amann, L'époque carolingienne (Paris: Bloud and Gay, 1947), 202: "Charlemagne a une piété de laïque! Louis une dévotion de prêtre ou de moine." Also see Arthur Kleinclausz, L'empire carolingien (Paris: 1902); Ferdinand Lot, La naissance de la France (Paris: 1947); and Louis Halphen, Charlemagne et l'empire carolingien (Paris: 1947). Thomas Noble further explores this early historiography in "Louis the Pious and his Piety Re-reconsidered," Revue belge 58 (1980): 305.

${ }^{5}$ Amann, 202: "la réforme de l'Église, la réforme surtout de l'état monastique."

${ }^{6}$ Amann's negative framing of Louis in comparison to his father becomes apparent in the statement, "Louis a manqué, pour être un grand souverain, cette promptitude et ce développement de l'intelligence... Louis n'ait pas su porter l'énorme responsabilité que lui laissait la mort de Charlemagne." See Amann, L'époque carolingienne, 202.

${ }^{7}$ Noble, "Louis the Pious and his Piety Re-Reconsidered," 306-309. This argument arose from Noble's previous article, "The Monastic Ideal as a Model for Empire: The Case of Louis the Pious" Revue bénédictine 86 (1976): 235-50. For further discussion on the impact of Noble's reframing of Louis, see Jasmijn Bonvendeert, "Royal or Monastic Identity? Smaragdus' Via Regia and Diadema Monachorum," in Texts and Identities in the Early Middle Ages," ed. Richard Corradini et al., 239-251 (Vienna: Verlag, 2006).

$$
{ }^{8} \text { Ibid., } 309 .
$$


suggests that both Charlemagne and Louis are responsible for renewal, not just

Charlemagne alone. In his framing, Louis' character becomes equal to or surpasses that of Charlemagne, while the narrative of the imperial Carolingian renaissance remains intact.

Building on Noble's assertion that the character of Louis has been misrepresented in Carolingian scholarship, Courtney Booker provides a rational for the framing of Louis as the Carolingian emperor who brought about the end of monarchical sovereignty and the decline of the empire. Examining early modern and modern narratives surrounding the emperor, he argues that historians have dramatized the Carolingian period and transformed it into a strategic narrative by actively seeking out culpability and motive in order to explain the ruin of the empire. He underscores that scholars assume, "if the once-great empire had risen on the powerful and magnanimous shoulders of Charlemagne, its fall must likewise be attributable both to weakness and to the selfserving interests of individuals." 9 Thus, the negative portrayal of Louis is the result of an overly simplistic need of historians to balance the narrative of the rise and fall of the Carolingian empire.

A consequence of the focus on Louis is that scholars are unsurprised at the production of capitulary texts pertaining to monasticism during his early reign. Since they take his monastic attachments to be well established, they assume that his piety

\footnotetext{
${ }^{9}$ Courtney Booker, Past Convictions: The Penance of Louis the Pious and the Decline of the Carolingians (Philadelphia: University of Pennsylvania Press, 2009), 34. Booker concentrates on narratives surrounding the events of 833 , when Louis gave public penance following a successful military coup organized by his fideles and sons. While Booker emphasizes that primary source evidence continues to depict Louis as politically successful, I would underscore that positive portrayals of Louis as a powerful emperor are also found in pre 830 texts. The most commonly cited texts which present Louis in a positive light include Ardo's Vita Benedicti, which I examine in chapter 4, and Ermoldus Nigellus' Carmen in Honorem Hludowici. See Ermoldus, Ermoldi Nigelli Carmina, MGH Poetae Latini aevi Carolini 2, ed. Ernestus Duemmler (Berlin: 1884), 1-93.
} 
directed Carolingian monastic reform. Seeing the emperor as central to decision making in Carolingian times and believing law to be key to medieval reform efforts, ${ }^{10}$ these political historians viewed capitularies as the central vehicle for reform. Carlo de Clercq, for instance, groups the capitulary texts together under the title "the Frankish legislation,"11 and asserts that the production of legislation was the defining characteristic of the Carolingian renaissance. ${ }^{12}$ He places emphasis on the contents of the capitularies as the ideals of reform and dismisses any resistance to them. ${ }^{13}$ By suggesting that the capitulary texts were legislation, de Clercq teleologically associates modern conceptions of law and power with Carolingian capitulary production by presenting a unified Frankish people who responded to the commands of a single emperor. Interpreting Louis in this manner, de Clercq assumes that the emperor himself produced and condoned the capitulary texts and initiated a successful reform movement. ${ }^{14}$

${ }^{10}$ As I demonstrate in my analysis of capitularies, commentaries, and hagiography in the following chapters, there was in fact little centralitization in Carolingian church and politics. The diversity between these three genres is so manifest that not one text presents the same monastic program.

${ }^{11}$ The legislation to which de Clercq refers here is most likely composed of the Admonitio Generalis (789), the 802 capitulary, and the 813 capitulary during the reign of Charlemagne and the capitularies of $816 / 817,818 / 819,829$, and 845-847 during the reign of Louis. For more on capitulary production during the Carolingian period see Carlo de Clercq, La legislation religieuse Franque. Tome II: De Louis le Pieux à la fin du IX' siècle (Anvers: 1958); and Rosamond McKitterick, "Legislation for Reform: The Capitularies and Conciliar Decrees," in The Frankish Church and Carolingian Reforms789895 (London: Royal Historical Society, 1977), 1-44. I discuss early ninth-century capitulary production further in chapter two, 30-57.

${ }^{12}$ Carlo de Clercq, La legislation religieuse Franque. Tome II: De Louis le Pieux à la fin du IX siècle (Anvers: 1958), 3. interpréter."

${ }^{13}$ Ibid., 6: "la sphère exacte d'influence des textes qui s'y rattachent est plus difficile à

${ }^{14}$ Unlike Amann, however, de Clercq suggests that there was more continuity between the reigns of Charlemagne and Louis by noting that the latter continued the religious reform which began in the time of his father. Although both Amann and de Clercq unite ideas of reform and kingship, Amann understands the reforms of Charlemagne and Louis as separate, while de Clercq underscores their cohesiveness. They both, however, agree that there was a reform, and they support this argument largely through capitulary evidence. See de Clercq, La legislation religieuse Franque, 3. 
Also interested in placing the capitularies within the canon of legal history texts, François Ganshof emphasizes the connection between imperial authority and capitulary production. He asserts, "the instrument chosen above all others to mold the institutions [of the Frankish kingdom] was the capitulary." 15 He further argues that the imperial goal of the capitularies was to correct practices by returning to traditional Roman-style regulations, while at the same time adapting them to new situations. ${ }^{16}$ In other words, the capitularies were the legislative tool which Carolingian emperors, and Charlemagne in particular, used to craft a new and cohesive empire through a series of unified ideals. Thus, Ganshof furthers the narrative that historians ought to understand Carolingian monasticism through the examination of capitulary reform documents since they exercised imperial authority and drew legitimacy from the past. ${ }^{17}$

Ganshof and de Clercq draw attention to the Carolingian capitulary texts because they are interested in framing the documents as predecessors of modern legislation. The monastic content of the capitularies was of little concern to both historians, as they show

\footnotetext{
${ }^{15}$ François Louis Ganshof, Frankish Institutions Under Charlemagne, trans. Bryce Lyon and Mary Lyon (Providence: Brown University Press, 1968), 4.

${ }^{16}$ Ibid.

${ }^{17}$ There are a number of studies of the Frankish Church which continue to draw conclusions about early ninth-century monasticism predominantly from capitulary evidence. This is problematic as other sources which I examine in chapters three and four present very different monastic programs than that which the capitularies suggest. Rosamond McKitterick's study of the Frankish Church begins with a discussion of "capitulary and conciliar legislation in the context of the shaping of a Christian society" (McKitterick, The Frankish Church and the Carolingian Reforms, 1). For her, the definition of the Carolingian period is their extensive use of capitularies, which "determined a program of ecclesiastical and intellectual reform" (ibid., xv). Her main interest in the Frankish church was, therefore, to lay out capitulary changes and amendments.

J.M. Wallace-Hadrill also mimics this approach, as he frames the entire period of Charlemagne and Louis' reigns as a series of reforms which are traceable through capitulary legislation (The Frankish Church, 258). He notes that the difference between Charlemagne and Louis' reigns is that Louis focuses on reforming monasticism. He writes, "with Louis the Pious we move into a different atmosphere, rather monastic than Episcopal and heavily flavoured with the reforming ideals of Louis's Aquitanian mentor, Benedict of Aniane" (ibid., 263). Both McKitterick and Wallace-Hadrill, therefore, present interpretations of Carolingian monasticism similar to that of Semmler and Ganshof, in which reform is central because it presents a unified series of ideals within the capitulary sources.
} 
themselves to be most interested in how they construct and exert imperial power. Rather than attempting to paint a portrait of Carolingian monasticism, they merely offer a narrative of constitutional progress: imperial capitularies instigated a series of reforms bringing about an increasingly civilized and ordered empire.

Josef Semmler was one of the first historians who examined the Carolingian monastic capitulary documents specifically for their monastic content and discussion of customs. He sought to provide new rigour to the study of Carolingian monasticism by reediting the Aachen capitulary texts to modern standards. ${ }^{18}$ Semmler's edition, however, does not represent a radical break from previous scholarship, as he sees capitulary evidence as a support for the thesis of Carolingian renaissance. ${ }^{19}$ His edition suggests that the Aachen capitularies represent the new monastic way of life which redirects attention to the topic of monasticism, rather than using the monastic capitularies exclusively to support the thesis of Carolingian imperial renaissance.

A major difference between the work of Semmler and that of Amann and de Clercq is a shift in causation: Benedict of Aniane takes the place of Louis the Pious as the true Carolingian reformer. Though maintaining a focus on the 'great man' of history, he proffers that Benedict of Aniane enforced and modified $R B$ as the official monastic rule throughout the empire. ${ }^{20}$ Within this interpretation, Benedict becomes responsible for

\footnotetext{
${ }^{18}$ Semmler also writes about other capitularies besides the Legislatio Aquisgranensis. See J. Semmler and A.E. Verhulst, "Les statuts d'Adalhard de Corbie de l'an 822" Le Moyen Age 17:4 (1962): 91-122 and 233-269.

${ }^{19}$ Semmler, "Introductio," Legislatio Aquisgranensis, CCM 1, 425-426: "Quae igitur res monasticae aevi huius quodammodo in historiam convertuntur imperii."

${ }^{20}$ Semmler, Legislation Aquisgranenesis, 425: "Benedictus enim Anianensis... Regulam s. Benedicti unicam vivendi normam monachis constituit traditionesque monasticas in Francorum regno Italiaque pollentes colligens s. Benedicti Regulae adaptavit.”
} 
monastic reform with Louis as his distinct patron. This argument, however, does not significantly alter previous interpretations, as monastic reform remains successful due to imperial support, with a minor casting change-Benedict now acting as reformer rather than Louis. By recasting an abbot in this reforming role, however, Semmler's scholarship places Carolingian monasticism at the forefront of his discussion.

Semmler's edition of the Aachen capitularies had a significant impact upon the work of subsequent scholars, who largely accept his suggestion that the texts initiated an empire-wide reform. Consequently, they frequently study other Carolingian monastic texts within the context of this reform and emphasize their adherence to, or divergence from, the Aachen capitularies. Walter Horn and Earnest Born's examination of the Plan of Saint Gall is one of the first studies to employ this approach. ${ }^{21}$ While Horn and Born consult other early ninth-century monastic texts, such as hagiography and commentaries on $R B$, they maintain, "the Plan of St. Gall was a product of the monastic reform movement"- a movement which they tie directly to the Aachen capitulary texts. ${ }^{22}$ The justification for their study, therefore, resides in the fact that the Plan visually depicts the ideals of the monastic reform outlined in the capitularies. ${ }^{23}$ In their opinion, the reason we ought to study the Plan is to obtain a better understanding of the monastic reform

${ }^{21}$ See Walter Horn and Ernest Born, The Plan of St. Gall (Berkeley: University of California Press, 1979). Horn published independently of Born in early studies including his article "On the Origins of the Medieval Cloister" Gesta 12:1 (1973): 13-52.

${ }^{22}$ Horn and Born, The Plan of Saint Gall, 22. Horn makes this argument more explicit. Taking the same approach as Semmler, he asserts that Benedict of Aniane was the "great monastic reformist" who, with the "support of the young king Louis the Pious," spread the Benedictine ideal "far and wide in the Frankish orbit west of the Rhine" (Horn, "On the Origins of the Medieval Cloister," 13). The Plan of St. Gall, in Horn's opinion, "was one of the products of that drive toward unification" (ibid., 37). Thus, Horn suggests that this Plan ought to be considered within the body of capitulary texts demonstrating Carolingian monastic reform. See Walter Horn, "On the Origins of the Medieval Cloister," 13-52.

${ }^{23}$ Horn and Born, The Plan of Saint Gall, 20-22. 
movement. In this manner, Horn and Born's study perpetuates the centrality of Aachen capitulary sources and Semmler's assumption of universal Carolingian monastic reform. $^{24}$

Whereas Horn and Born use the Plan of Saint Gall in order to bolster support for Semmler's argument that the capitularies universally reformed Carolingian monasticism, other historians have begun to concentrate on texts which show deviation from the Aachen capitularies. Maria Hildebrandt, for example, points to conflicts which exist between the Plan and the capitulary texts in relation to the Carolingian external school. She criticizes their study, highlighting that it presents an incorrect analysis of the Plan by downplaying the differences between the capitulary texts and the sketch. ${ }^{25}$ Although Hildebrandt's study concentrates on the specific shortcomings of Horn and Born's work, her criticism of their assumption that the Aachen capitularies universally reformed monastic practice throughout the empire applies to most pre-1980s scholarship. Semmler, Ganshof, de Clercq, and Amann, for instance, all contend that monks conformed to the capitularies.

Hildebrandt develops a new approach to monastic writing during the ninth century and argues that the capitulary texts represented an ideal which did not always come to fruition in practice. She writes, "the ideal of enclosing monks, articulated in the monastic reform movement of $816 / 817$, probably remained largely an ideal." ${ }^{26}$ Thus,

\footnotetext{
${ }^{24}$ Horn and Born's interpretation of the Plan of Saint Gall differs from my own interpretation of the document which I provided above. Whereas they suggest that the Plan reflects reform ideals, I argue that it diverges from the monastic program which the Aachen capitulary texts propose, particularly on the subject of interaction with guests.

${ }^{25}$ M.M. Hildebrandt, The External School in Carolingian Society (New York: E.J. Brill, 1992), 17.

${ }^{26}$ Ibid., 129.
} 
Hildebrandt asserts that there was a reform movement, but because we see conflicting depictions in other monastic sources from the same period, we ought to conclude that monastic practices remained fragmented and fluid. What continues to be problematic about her approach is that she maintains that monks universally desired reform, but were unable to conform to it in practice.

Hildebrandt's scholarship inspired a new a series of studies that also investigated conflicting practices in post-816 monastic writing and perpetuated her framework of reform ideals versus practiced realities. Mayke de Jong, for example, explores these concerns in her work on the theory and practice of child oblation within the Carolingian kingdoms. ${ }^{27}$ She notes:

by 813 the era of mixed rules had not come to an end, and ancient sees like Rheims that staunchly defended older monastic traditions were not yet ready for the next stage of reform, which entitled not only one rule (una regula), but also a unified custom (una consuetudo). ${ }^{28}$

This explicit recognition that there was no sudden shift in the early ninth century from fragmented to unified forms of monasticism dispels the dominance of much earlier scholarship which sees massive change arising from the influence of either Louis, Benedict, or the capitularies.

Although de Jong consults many non-capitulary sources in her study, she maintains a clear distinction between texts with legal authority and those without. What instils legal authority within these texts, however, is somewhat more ambiguous. For example, de Jong considers certain aspects of Smaragdus' Expositio in Regulam sancti

\footnotetext{
${ }^{27}$ Mayke de Jong, In Samuel's Image (New York: E.J. Brill, 1996), 14.

${ }^{28}$ Ibid., 58-59. De Jong repeats this argument in a later article. See Mayke de Jong, "Carolingian monasticism: the power of prayer," 631 .
} 
Benedicti to reflect legal ideals, while in other instances she suggests that he reveals contradictory practices. In a section discussing whether or not child oblates ought to be able to leave the monastery once they become adults, she contends that Smaragdus is in accordance with the Aachen capitularies and $R B .^{29}$ She later notes:

in practice Smaragdus was all too often faced with young monks who preferred the world to the monastery, for he makes the passing comment that 'although such a thing seldom happened then (i.e. Benedict's time), we know that it occurs quite frequently nowadays. ${ }^{30}$

De Jong presents a compelling argument that Smaragdus himself witnessd that ideals and realities differed in Carolingian monasticism. She concludes that Smaragdus, along with other members of the monastic community, were aware and accepting of the Aachen capitularies as an ideal and that he was unfortunately forced to concede to practical demands. $^{31}$

This argument assumes that Smaragdus' text sought to be entirely in accordance with the Aachen reform movement and that his Expositio in Regulam sancti Benedicti simply amends an oversight in the legislation. ${ }^{32}$ Consequently, de Jong's construction of the authority of the capitularies resembles that of previous scholars. Although she does not suggest the capitularies embody imperial power, she makes a distinction between

\footnotetext{
${ }^{29}$ De Jong, In Samuel's Image, 69. In this example, de Jong notes that the texts agree specifically over the terminology and definition of parentes. The full quote reads, "in accordance with the Aachen legislation, Smaragdus held that the parentes mentioned in $R B$ could only be a child's father and / or mother."

${ }^{30}$ Ibid., 69-70. Mayke de Jong translates the Latin: “Quod si tunc rare fiebat, nunc vero factum nos frequentissime esse cognoscimus."

${ }^{31}$ I should also note that de Jong is making a connection between $R B$ and the Aachen capitularies as well. I return to this idea in my second chapter, $30-57$.

${ }^{32}$ I demonstrate later in this thesis that many of Smaragdus' opinions on claustration varied from those of the capitulary documents associated with the Aachen reform movement. See chapter three, 58-81.
} 
certain types of "legal" sources which authoritatively reflect an ideal, and other sources which reflect the failure of practice to follow those ideals.

Interpreting Carolingian monasticism as an opposition of theoria versus praxis still gives causative primacy to the capitularies of 816 and 817 on the basis of very little evidence. The result is a self-imposed division in the primary source material, which encourages historians to neglect some sources and privilege others. ${ }^{33}$ Instead of perpetuating this division, I propose to reconsider the capitularies in light of other monastic texts from the early ninth century. The capitulary sources, I suggest, merely reflect the development of one monastic program amidst a multitude of other, sometimes conflicting, ideologies and customs in ninth-century monastic writing. In the following section, I will explore the problematic dominance of the capitulary texts in Carolingian monastic scholarship through a focused examination of the question of interaction between monks and outsiders during the eighth and ninth centuries.

\section{MONASTIC BOUNDARIES AND INTERACTION WITH THE OUTSIDE WORLD}

Historians suggest that when taken together, the Aachen capitulary documents from 816 / 817 and $R B$ depict the orthodox ideal of the separation of monks from the secular world characterizing the Carolingian period. They argue that Carolingian monastic communities may have ideally desired the monastery to be an isolated and pure

\footnotetext{
${ }^{33}$ Other scholars who express similar concerns include Richard Sullivan, "What Was Carolingian Monasticism? The Plan of St Gall and the History of Monasticism," in After Rome's Fall, ed. Alexander Murray (Toronto: University of Toronto Press, 1998), 251-287; Sullivan, "The Carolingian Age: Reflections on its Place of History in the Middle Ages," Speculum 64, no. 2 (1989): 267-306; Michèle Gaillard, D'une réforme à l'autre (816-934): Les communautés religieuses en Lorraine à l'époque Carolingienne (Paris: Publication de la Sorbonne, 2006); M.D. Ponesse, "Smaragdus of St. Mihiel and the Carolingian Monastic Reform,” Revue Bénédictine 116 (2006): 367-392.
} 
site, but in practice monks had to interact with the outside world in order to meet basic practical needs. ${ }^{34}$ Scholars, therefore, contrast the image of a clean and secluded monastery with the dirty, corporeal and unholy depiction of the secular world. If these two opposing bodies were ever to meet, they suggest that the grime of the world would soil the pristine monastery.

When considering the sketch of the cloister in the Plan of Saint Gall, for example, Horn and Born note, "a host of seculars... threatened to subvert the monastic ideal of exclusion from the world and its preoccupations." ${ }^{35}$ This secular threat posed a problem which the introduction of the cloister solved. They assert that the cloister functioned as a "monastery within the monastery" where religious purity might remain intact and removed from the outside world. ${ }^{36}$ Tying into their broader thesis which suggests that the Plan of Saint Gall visually depicts the capitulary documents, they interpret the drawing of the cloister as a visual representation of the Aachen ideal for monastic isolation. ${ }^{37}$ Despite clear evidence to the contrary, ${ }^{38}$ Horn and Born argue that the Plan shows the monastic desire for seclusion. They suggest that while guests may stay within the transitional space located between the monastery walls and the cloister, they do not

\footnotetext{
${ }^{34}$ The more influential of these studies include Horn and Born, The Plan of Saint Gall (Berkeley: University of California Press, 1979); John Van Engen, "The 'Crisis of Cenobitism' Reconsidered: Benedictine Monasticism in the Years 1050-1150," Speculum 61, no. 2 (1986): 269-304; M.M. Hildebrandt, The External School in Carolingian Society (New York: E.J. Brill, 1992); Mayke de Jong, In Samuel's Image (New York: E.J. Brill, 1996); Giles Constable, "The Realities of Reform: (2) Monastic Activities and Relations with Secular Society," in Reformation of the Twelfth Century (Cambridge: Cambridge University Press, 1998).

${ }^{35}$ Horn and Born, The Plan of Saint Gall, vol.1, 241.

${ }^{36}$ Ibid.

${ }^{37}$ This parallels my assertion above that Horn and Born consider the Plan to be a visual extension of the monastic capitularies of 816 and 817.

${ }^{38}$ See introduction, 1-3.
} 
penetrate the interior cloister where the majority of monks primarily dwell. Furthermore, they assert that monks have more control over how and when they might receive guests and deal with secular affairs.

Hildebrandt nuances the problem of claustration in her study of the external school in the monastery. Unlike Horn and Born, she emphasizes conflicting practices. Although the monastic ideal was to "keep the world out," she notes, "in reality, monasteries found themselves in constant struggle with the world, filling social, religious, and political needs. ${ }^{39}$ For Hildebrandt, the cloister did not prevent monks from needing to interact with the outside world. She underscores that monks continued to play a role outside the monastery during the early ninth century and, therefore, did not remain separated in their cloisters. ${ }^{40}$ These conclusions fuel Hildebrandt's general conception of Carolingian monasticism as a series of coupled ideals and practices by portraying claustration as failed ideal. ${ }^{41}$ Within this framework, texts reflecting ideals depict the monastery as a completely isolated site, however, the fundamental practical needs of the monastery require a minimal level of external interaction for food, recruitment, supplies, etc. In practice, therefore, Hildebrandt suggests that monks continued to, at least grudgingly, engage with the world. ${ }^{42}$

${ }^{39}$ M.M. Hildebrandt, The External School in Carolingian Society, 37.

${ }^{40}$ Ibid., 27.

${ }^{41}$ Ibid. Hildebrandt highlights that the problem surrounding claustration and the external school presented a pressing concern during the Aachen reform movement. She notes that there was uncertainty as to whether or not monks ought to "honor the rule of St. Benedict or to circumvent it." Although she does not pursue this thought any further, it implies that he sees division between $R B$ and the $816 / 817$ capitularies.

${ }^{42}$ Hildebrandt's conceptions surrounding the monastic desire for isolation, however, are not simply the reflection of the reform narrative in Carolingian monasticism. Other scholars also consider interaction with the outside world to be a matter of necessity. Giles Constable asserts a similar argument regarding Cistercian monasteries which "all shared an ideal of withdrawal and seclusion," however, in 
Contrary to Hildebrandt, de Jong does agree with Horn and Born's conclusion that the construction of the cloister kept "the outside at bay." 43 Posing the same question of how to "safeguard prayer and stability" within the "hustle and bustle" of the secular world inside the monastery, she too suggests that the cloister provided a solution as an inner sanctuary. ${ }^{44}$ While de Jong is correct to point out that Carolingian monks took great care to perpetuate an image of themselves as cloistered, she assumes that claustration refers to permanent monastic isolation within the cloister. She concludes that monks would have understood interaction with the outside world as problematic because it tainted their seclusion.

De Jong goes further, however, by noting that monastic prayer and purity was not only important to monks, but to secular rulers as well. Acting as "powerhouses of prayer," monasteries served as intercessors for the salvation of the secular community. ${ }^{45}$ In order to have the most intercessory power, it was essential that monks "have clean hands" and "never leave their monastery unless compelled by necessity."46 Carolingian emperors had a vested interest in protecting the purity of monasteries because this ensured that they received the least tainted intercessory product. This assertion buttresses

practice "very few were able to live entirely by the labour of their own hand without any outside help or sources of revenue" (Constable, "The Realities of Reform," 209 and 213). Thus, both Constable and Hildebrandt frame interaction with the world outside the cloister as an undesirable problem with which monasteries were forced to engage. See Giles Constable, "The Realities of Reform," 209-256.

${ }^{43}$ Mayke de Jong, "Carolingian monasticism: the Power of Prayer," 623.

${ }^{44}$ Ibid., 637.

${ }^{45}$ Ibid., 651.

${ }^{46}$ Mayke de Jong, "Imitatio Morum. The Cloister and Clerical Purity in the Carolingian World," 50 and 52. 
the argument that Carolingian emperors had an interest in furthering the reform because it helped them achieve salvation.

What is most problematic about the studies of Horn and Born, Hildebrandt, and de Jong in regards to their discussion of interaction with the outside world is their interpretation of claustration. Each historian assumes that monastic claustration during the Carolingian period primarily refers to the residence of a monk within a physical cloister. This claustration is only possible when a wall separates monks from the outside world and when outsiders cannot penetrate that boundary. They suggest that total separation was the monastic ideal, an ideal which they understand as originating from the Aachen capitulary texts. In practice, however, they note that worldly interaction was necessary in order to survive. Thus, they conclude that interaction served a functional purpose for monks, but otherwise they scorned and avoided contact.

Only very recently has an alternative method of understanding Carolingian monastic interaction emerged. ${ }^{47}$ Reflecting on the room for accommodation expressed in the Plan of Saint Gall, Richard Sullivan asserts that Carolingian monasteries had to potentially contend with an extremely high volume of traffic. By his count, the Plan could accommodate " 80 to 150 [guests], equalling or exceeding the $90-110$ monks" that could be living in the monastery. ${ }^{48}$ Expressing a very different interpretation of the Plan than that of Horn and Born, Sullivan contends that the physical boundaries separating the cloister from the rest of the monastery are misleading because they do not reflect the

\footnotetext{
${ }^{47}$ As far as I am aware, Sullivan is the only scholar of Carolingian monasticism who suggests new ways of interpreting interaction between monasteries and the outside world.

${ }^{48}$ Richard Sullivan, "What Was Carolingian Monasticism," 275. Sullivan also notes that "a full complement of guests might have added another 115 laymen present at the monastery on any particular day."
} 
level of interaction which monks and guests would have shared residing on opposite sides of the cloister wall. ${ }^{49}$

Sullivan bases this conclusion on the assumption that although they may not physically occupy the same room, both monks and guests must have been aware of each other's presence through sight, hearing, and even smell. ${ }^{50}$ He writes, "by the time for compline, the chorus psellentium probably had to contend with sounds not noted in their liturgical books; perhaps the revelry still sounded across the complex when the monks arose at 2:00 am for the first service of the day." ${ }^{, 51}$ Sullivan, therefore, emphasizes the interaction between monks and outsiders, suggesting that this contact aided monks on their "quest for spiritual perfection." ${ }^{52}$ In this interpretation, a central message of the Plan is:

monks should dwell in a 'city' where everything that the contemporary world possessed in terms of sustaining earthly existence and promoting human wellbeing could be put to use in nurturing the spirit. Such a 'city' was possible only if there was ongoing interaction between the cloister and the world. ${ }^{53}$

In his interpretation, it is very clear that the cloister was not isolated from the outside world. Rather, Sullivan stresses that the monks engage in worldly exchange and even desire to maintain close contact.

Although Sullivan remains one of the few scholars to express an alternative approach to understanding the relationship between the monastery and the world within

\footnotetext{
${ }^{49}$ Ibid., 276.

${ }^{50}$ Ibid., 277.

${ }^{51}$ Ibid. Sullivan mirrors this interchange of sounds between monks and guests in his description of how animals were "located literally up against the walls of the monks' sacred space" (ibid., 277-279).

${ }^{52}$ Ibid.

${ }^{53}$ Ibid., 282.
} 
the field of Carolingian monastic studies, scholarship on claustration from other periods is also useful. For instance, Barbara Rosenwein frames the monastery of Cluny during the tenth and eleventh centuries as connected to a "tightly woven social network" of outsiders, despite claiming to enforce an extremely high level of claustration. ${ }^{54}$ This network consisted of family groups and neighbours who she argues were part of an "ongoing process... of fluid alliances." monastery and the outside world was not problematic, but rather necessary and even expected by the monks of Cluny. Rosenwein explores the inter-worldly relationships through an examination of enmity and friendship between abbots and nobles, suggesting a less solid boundary around the monastery than that which de Jong, Hildebrandt, or Horn and Born offer.

Other monastic scholars also argue that boundaries enclosing monasteries from the outside world were not always as firm as other historians suggest. Examining sources from the second through fifth century, Daniel Caner notes that wandering monks in the eastern Mediterranean were a normal part of the economic and social fabric.

Furthermore, he asserts that a stable form of coenobitic monasticism was not always the norm, but rather "became recognized as legitimate... while others became marginalized and repudiated" throughout late antiquity. ${ }^{56}$ Similarly, Maribel Dietz underscores the fact that the early church was in many ways a "highly mobile institution," particularly in the

\footnotetext{
${ }^{54}$ Barbara Rosenwein, Thomas Head, and Sharon Farmer, "Monks and their Enemies," Speculum 66, no. 4 (1991): 777 .

${ }^{55}$ Ibid., 766.

${ }^{56}$ Daniel Caner, Wandering, Begging Monks: Spiritual Authority and the Promotion of Monasticism in Late Antiquity (Berkeley: University of California Press, 2002), 4.
} 
form of conciliar voyages, missionary expeditions, and pilgrimages. ${ }^{57}$ This is not to suggest that travel outside the monastery was endorsed at all times. Rather, Dietz and Caner's arguments highlight the fact that ideas surrounding early monastic travel were part of an ongoing negotiation, which many early writers openly debated. ${ }^{58}$

Megan Cassidy-Welch also explores physical and mental boundaries in a later Cistercian context, asserting that physical boundaries were much more permeable than mental or imagined boundaries. ${ }^{59}$ She asserts that physical boundaries demarcated monastic places. These included physical walls, gatehouses, the outer court and even the cloister itself. ${ }^{60}$ Whereas Horn and Born interpret the cloister as a solution to the problem of the outside world, Cassidy-Welch frames the cloister as one of a series of boundaries which expressed "ideas of transition." ${ }^{\text {61 }}$ In other words, while all physical barriers separated the monastic sphere from the outside world, they were also places of transition which rendered the inner monastery more sacred. Though transition between these places often involved ritual acts, they were not impossible to cross and their purpose was not to bar complete access from or to the outside world. ${ }^{62}$

\footnotetext{
${ }^{57}$ Maribel Dietz, Wandering Monks, Virgins, and Pilgrims: Ascetic Travel in the Mediterranean World, A.D. 300-800 (Pennsylvania: Pennsylvania State University Press, 2005), 24.

${ }^{58}$ Whereas Caner and Dietz's texts both suggest that this negotiation ended sometime between the seventh and ninth centuries, conflicting monastic sources suggest that it continued.

${ }^{59}$ Megan Cassidy-Welch, Monastic Spaces and their Meanings: Thirteenth-Century English Cistercian Monasteries (Turnhout: Brepols Publishers, 2001), 23.

${ }^{60}$ Ibid., 27- 28.

${ }^{61}$ Ibid., 33.

${ }^{62}$ See chapter three pages $58-81$. Smaragdus describes a number of ritual acts upon entrance to the monastery such as the kiss of peace, the washing of guests' feet and prostration mentioned in chapter fiftythree of the Expositio. I should also note here that while a physical person might not be able to enter as far as the inner cloister at all times, letters or objects which were associated with the outside world might and their presence was just as meaningful.
} 
Transitioning into or out of a monastic mental space, on the other hand, was much more difficult. Cassidy-Welch notes that Cistercian novices were taught mnemonic techniques of meditation which served to "train the mind to forget the experienced past... [and] to create a new past, full of new memories."63 These new memories, which focused on the Christian past and particularly Christ, served as a mental boundary between the secular and sacred worlds. Although this example is quite specific to Cistercian monasticism, it is useful to consider in the context of the Carolingian period because it provides a new way of interpreting how monks conceived of their world-inside and outside the cloister. Monks transitioned between various interior and exterior boundaries, but their purpose was not to halt interaction between monks and outsiders.

These studies all problematize the definitions of the cloister and interaction which Horn and Born, Hildebrandt, and de Jong establish, showing how primary source texts depict multiple forms of interaction between the monastery and the outside world. Rather than discussing a monastic ideal for isolation, they conclude that the cloister boundary between the sacred and secular worlds was often fluid. Cassidy-Welch, Caner, Dietz, and Sullivan all discuss interaction through the crossing of a physical boundary-travel beyond or within the monastery walls. Alternatively, Rosenwein discusses less physical forms of interaction, as much of what she cites consists of correspondence and reciprocity. ${ }^{64}$ This contrasting interpretation of interaction suggests that contact with the outside world did not necessarily pose a threat to monastic claustration and emphasizes that monks could conceptualize interaction as both desired and beneficial.

\footnotetext{
${ }^{63}$ Cassidy-Welch, Monastic Spaces and their Meanings, 40.

${ }^{64}$ Rosenwein, et al., "Monks and their Enemies," 773-777.
} 
CONCLUSION

Studies on claustration in the centuries which preceded and followed the Carolingian period indicate that monks desired and pursued contact with the outside world. With few exceptions, historians have rarely considered how monks conceived of and sought out interaction during the ninth century. An emphasis on the Aachen capitulary texts stemmed from a general desire among scholars to frame ninth-century monasticism as part of a Carolingian cultural and intellectual renaissance. Eager to underscore the differences between Merovingian and Carolingian monasticism and the development of a hierarchical monarchy, therefore, historians highlighted the capitulary texts which they assumed to carry legal authority akin to modern legislation.

The following chapter challenges this problematic interpretation of the Aachen capitulary texts by re-examining the documents beyond the context of reform. Adopting the approach that these texts were no more influential than any other piece of widely disseminated monastic writing, I explore the authority behind, and monastic program within, the capitularies sources. As well, I reconsider the manner in which the capitularies frame contact with outsiders and suggest that their interest in the cloister does not render interaction undesired. 


\section{CHAPTER TWO}

\section{INTERACTION THROUGH THE RECEPTION OF GUESTS IN AACHEN CAPITULARY EVIDENCE}

Indeed, many monasteries [in Francia] had once been established by way of general rule, but little by little the rigidity softened, and the order had lost regularity. That however there might be one wholesome usage for all monasteries, as there was one profession by all, the emperor ordered the fathers of monasteries gathered. Together with as many monks as possible, the gathering persisted for several days... [Benedict of Aniane] then produced for the emperor [Louis the Pious] a capitulary decree for confirmation so that he might order monks to observe the decree in all the monasteries situated in his kingdom... And all monasteries thus were returned to the form of unity as if they were taught by one teacher in one place. Uniform measure having been related in drink, in food, in vigils, in singing, is to be observed by all. ${ }^{1}$

This passage is an excerpt from the vita Benedicti, which the monk Ardo wrote soon after the death of Benedict of Aniane in 821. In his account of the councils of Aachen—which many scholars take as a uniquely authoritative account-Ardo seeks to identify Benedict of Aniane as the sole composer of a single codification that reformed Carolingian monasticism. This description is misleading, however, given that there was already a long tradition of ecclesiastic capitularies stemming back to the beginning of

\footnotetext{
${ }^{1}$ Ardo of Aniane, Vita Benedicti Anianensis, cols. 0377B-0377D: "Multa denique monasteria errant que quondam regulariter fuerant instituta; set paulatime tepescente rigore, regularis pene(s) deperierat ordo. Ut autem, sicut una omnium erat professio, fieret quoque omnium monasteriorum salubris una consuetudo, jubente imperatore adgregatis cenobiorum patribus, una cum quampluribus monachis perplures resedit dies... etiam capitularem institutum imperatori confirmandum prebuit, ut omnibus in regno suo soditis monasteriis observare preciperet... cunctaque monasteria ita ad formam unitatis redacta sunt, ac si ab uno magistro et in uno imbuerentur loco. Uniformis mensura in potu, in cibo, in vigiliis, in modulationibus cunctis observanda est tradita." All translations of vita Benedicti Anianensis adapted from Allen Cabaniss, trans., Benedict of Aniane: The Emperor's Monk (Kalamazoo: Cistercian Publications, 2008).
} 
Carolingian rule during the early eighth century and continuing well after Benedict's death. $^{2}$

Ardo's depiction of a singular capitulary is, therefore, problematic and the picture of Carolingian monasticism relying solely on his account has also overemphasized Benedict's role in the reforms. Furthermore, it has allowed historians to construct a simplified narrative of the reform councils and capitulary production. In contrast to his narrative, the surviving textual evidence makes no mention of Benedict, and gives evidence that they were the product of collaboration between many abbots and monks throughout the empire. ${ }^{3}$ Understanding the capitularies as the product of multiple authors emphasizes that the Aachen reform councils of 816 / 817 were a forum for debate on monastic issues that expressed diverse, and sometimes conflicting, opinions.

Ardo's narrative does make one important observation in line with the attitude of the capitulary authors. He notes that Carolingian monks shared an interest in establishing monasticism as a vocation distinct from other ecclesiastic roles. ${ }^{4}$ The capitulary of 816 differed from previous ecclesiastic capitulary texts by addressing the monastic community directly, which shows that the monastic authors conceived of their way of life

${ }^{2}$ There was a period between Merovingian and Carolingian rule in which very few monastic capitularies were produced. The earliest reference to Carolingian monastic capitularies of which I am aware appears in the letters of Boniface from the second quarter of the eighth century. See Die Briefen des hl. Bonifatius and Lullus, MGH ES, ed. Michael Tangl (Berlin, 1916), letter 50, 80-86.

${ }^{3}$ Josef Semmler, ed., Legislatio Aquisgranensis, CCM 1 (Sieburg: 1963), 432-481. These captitulary texts include the Synodi primae Aquisgranensis acta praeliminaria, Actuum praeliminarius synodi primae Aquisgranensis commentationes sive statuta Murbachensis, Synodi primae Aquisgranensis decreta authentica, and Synodi secundae Aquisgranensis decreta authentica.

${ }^{4}$ Mayke de Jong discusses the goals of these capitularies. She suggests that Carolingian abbots and monks stressed the need for not only "one rule (una regula), but also a unified custom (una consuetudo)." To this I would add the idea that the capitularies also emphasize the importance of one profession (una professio). By addressing only monks in this capitulary for the first time, they sought to construct a unified monastic profession. See de Jong, "Carolingian monasticism: the power of prayer," in The New Cambridge Medieval History II, ed. Rosamond McKitterick (Cambridge: Cambridge University Press, 1995), 631. 
as separate not only from other lay positions but also from other ecclesiastic roles. ${ }^{5}$ Key to the construction of the monastic way of life within these capitula was the physical place of the monastery, which the authors of the capitularies cautioned against ever leaving. Previous scholarship concluded that this concern with demarcating space was born from a strict concern for seclusion, but I view it more as part of the Carolingian debate on how to identify the distinct characterization of different members of the church. The desire to live within the cloister did not render interaction with the outside world unwelcome. Rather, the capitulary texts taken by historians as most strictly arguing for seclusion in fact encouraged interaction as long as this exchange could be brought within the walls of the monastery itself.

This chapter seeks to explore the manner in which capitulary texts encouraged interaction with the outside world. As the texts valorize monks' physical presence within the cloister, I argue that the capitularies advocated for moving interaction with outside individuals within the monastery. In order to explore the ways in which the capitulary texts underscore the place of the monastery as the defining characteristic of the monastic way of life, I consider historiographic assumptions concerning the documents, establish the secular and canonical trends from which they emerge, and analyze the approach to interaction which the capitularies present.

\section{AUTHORSHIP, CHRONOLOGY, AUTHORITY: ASSUMPTIONS IN SCHOLARSHIP}

While Ardo presents Benedict as the producer of a solitary 816 capitulary at the palace of Aachen, Josef Semmler's 1963 edition identified three different versions of the

\footnotetext{
${ }^{5}$ The manner in which early ninth-century texts construct their monastic programs varies in different texts. I discuss this in regards to other sources in chapters three and four.
} 
816 text, surviving in nine manuscripts. To these, he added a fourth capitulary text ${ }^{6}$ appearing in three of these manuscripts which indicates that the reform debates continued the following year (817). ${ }^{7}$ The first of these texts is the Acta praeliminaria, a document containing twenty-nine capitula which Semmler suggests was an initial draft of the Aachen 816 decrees. The second text, the Statuta Murbachensis, he frames as an anonymously composed commentary on a select number of the Aachen capitula for the monastery of Murbach. Finally, Semmler asserts that the third and fourth texts, the Primae decreta and Secundae decreta, were the authentic capitula of Aachen monastic capitularies from 816 and 817 respectively. Together, these two capitulary texts laid out seventy-nine capitula that regulated monastic practice. ${ }^{8}$

Despite the fact that Semmler identifies many different Aachen capitulary texts, past historiographic assumptions about the capitularies have continued to persist. While the 816 texts are seen as expressing the same sentiments, the text changes (at times dramatically) between them-suggesting a diversity of opinion. That subsequent revision occurred in 817 , moreover, conclusively shatters an idea of a single unified reform expressed in Ardo's narrative. In the following discussion, therefore, I wish to critique three assumptions in Semmler's edition which impacted subsequent scholarship: on authorship, chronology, and imperial authority.

\footnotetext{
${ }^{6}$ Semmler notes that this fourth capitulary from 817 is found in three of the same manuscripts containing some of the capitularies from 816 . Thus, the total number of manuscripts in which versions of the capitularies appear remains nine.

${ }^{7}$ Semmler thus imposes a chronological order on the four texts suggesting that the Acta praeliminaria was written first in 816, and from this draft came the Statuta Murbacensis, the Primae decreta, and finally the Secundae decreta.

${ }^{8}$ Semmler also notes that these two texts do survive together in some manuscripts and suggests that this combined version must be the text which Ardo notes that Benedict of Aniane edited for Louis the Pious. See Ardo, vita Benedicti Anianensis, chapter 50, col. 377C; and Regula sancti Benedicti Abbatis Anianensis sive collection capitularis, ed. Semmler, CCM 1 (Sieburg: 1963), 503-536.
} 
Ardo's description of the Aachen reform councils, greatly influenced Semmler's interpretation of the capitularies. He echoes Ardo in seeing that a group of abbots and monks met at Aachen in order to discuss monastic regulations, but that Benedict of Aniane alone subsequently laid out a series of capitula at the request of Louis the Pious which summarized their discussions. ${ }^{9}$ By framing the texts in this manner, Semmler emphasizes Benedict of Aniane's role in the production of the capitulary texts and implies that each text shares a common author.

Other historians link the emperor himself to the production of the capitularies, implying that Louis the Pious was either co-architect or the main instigator behind the texts. Thomas Noble follows Semmler's characterization and suggests that Louis presided over the synods. He and Benedict of Aniane "shared a burning zeal for monastic reform," Noble argues. ${ }^{10}$ Attempting to reconstruct the scholarly portrayal of Louis as a weak emperor, Noble uses the vita Benedicti in order to bolster support for his claim that Louis and Benedict maintained a close relationship, and implies that both men contributed to the production and authorship of the texts. Gerhard Schmitz, however, argues that this portrayal of a connection between Louis and Benedict is a misinterpretation of Louis' imperial power, and asserts that scholars ought to consider Louis as the true author of the capitularies. ${ }^{11}$ He clearly attributes all capitularies from

\footnotetext{
${ }^{9}$ Semmler, "Introductio," Legislatio Aquisgranensis, CCM 1, 426: “Quarum consuetudinum Benedictus capitulare institutum arbitrio submisit imperatoris, qui illud ad modum Capitularium promulgans magistratibus missisque imperii exequendum tuendumque imposuit." He directly cites Ardo as the authority on this matter of authorship.

${ }^{10}$ Thomas Noble, "Monastic Ideal as a Model for Empire: The Case of Louis the Pious," Revue Bénédictine 86, 1976: 241-242.

${ }^{11}$ Gerhard Schmitz, "The Capitulary Legislation of Louis the Pious," in Charlemagne's Heir, ed. Roger Collins (New York: Oxford University Press, 1991), 433.
} 
this period, monastic or otherwise, to Louis himself. Further, he dismisses the idea that court advisors, such as Benedict, determined the content of "Louis's legislation." 12

Noble and Schmitz's contrasting views demonstrate that assumptions surrounding capitulary authorship tie into a much deeper debate concerning the range and efficacy of imperial power during the early ninth century. Much of this speculation, however, derives from Semmler's original emphasis on the narrative which Ardo presents in the vita Benedicti Anianensis and not within the capitulary texts themselves. The capitulary documents of 816 and 817 make no reference to any specific author, nor do they suggest that one author wrote all four of the documents. In fact, two of the texts note a collaborative effort in the production of the capitularies, stating that an anonymous group of abbots and monks "decreed that the following capitula be maintained inviolable by the regular clergy." ${ }^{\prime 3}$ When considering what the capitularies themselves say, without Ardo's contextualization, scholars must reconsider the role that either Benedict or Louis played in the production of the capitularies, and accept an anonymous and collaborative authorship.

In his edition, Semmler also constructs a misleading relationship between the four texts by emphasizing the "authenticity" of the Primae decreta authentica and the

\footnotetext{
${ }^{12}$ Ibid.
}

${ }^{13}$ The Acta praeliminaria contains no preface and does not suggest any author. In the preface to the Statuta Murbachensis, there is no direct mention of an author, however, it does state, "Ad memoriam vestram, fratres karissimi, revocare scripto decrevimus ea quae verbis et capitulis proxime a sancta synodo auribus vestris intimauimus" (Semmler, Statuta Murbacensia, 441). Here, the use of the verb intimauimus in the first person plural implies perhaps a collaborative authorship of some sort. The preface to the Primae decreta states, "abates cum quam pluribus una cum suis resedissent monachis haec quae subsecuntur capitula communi consilio ac pari voluntate inviolabiliter a regularibus conservari decreverunt" (Semmler, Primae decreta, 457). Once again, there is no specific author stated. Rather, the text implies a joint authorship. Finally, the preface to the Secundae decreta states in a very similar manner, "abbates cum quam pluribus residerent monachis haec quae subsequuntur capitula communi consilio ac pari voluntate inviolabiliter ovservari decreverunt" (Semmler, Secundae decreta, 473). 
Secundae decreta authentica, and consequently diminishing the content of the Acta

praeliminaria and the Statuta Murbachensis as mere drafts of the Primae decreta

authentica. The consequence of this naming and ordering is that ensuing scholarship has

tended to focus on those capitularies which Semmler deemed authentic. ${ }^{14}$

Although Semmler does not offer any explanation as to why the abbots and monks congregated for a second time in two years in the edition itself, E. Lesne posits

that the monks and abbots responsible for the reform council of 816 reconvened the

following year in response to a negative reaction from the broader Carolingian monastic

community to the original capitulary text. ${ }^{15}$ Whereas the Primae decreta was too

restrictive and harsh, Lesne argues that the Secundae decreta presented a more lenient

revision. ${ }^{16}$

\footnotetext{
${ }^{14}$ More recent studies which focus exclusively on the Primae decreta and Secundae decreta include Horn and Born, The Plan of Saint Gall (Berkeley: University of California Press, 1979); J.M. Wallace-Hadrill, The Frankish Church (Oxford: Oxford University Press, 1983); Gerhard Schmitz, "The Capitulary Legislation of Louis the Pious," 425-436; and Michèle Gaillard, D'une réforme à l'autre (816934): Les communautés religieuses en Lorraine à l'époque Carolingienne (Paris: Publication de la Sorbonne, 2006).

${ }^{15}$ E. Lesne, "Les ordonnances de Louis le Pieux," in Revue d'histoire de l'Eglise de France 6 (1920), 161-175, 321-338, and 449-488. Lesne's evidence for the claim that the Secundae decreta corrected the capitula of the Primae decreta is merely that a second synod was held in 817 . He states, "Au cours de ce Synode, plusieurs point avaint été laissé en suspens. Au mois de juillet 817, dans une assemblée où figuraient seulement des abbés et des moines, on procéda au palais d'Aix à une revision des précédents statuts. On les reproduisit en les enrichissant de disposition nouvelles" (Lesne, 167).

${ }^{16}$ For other scholarship which perpetuates Lesne's claim see Semmler, "Una regula, Una consuetudo," 1-49; Ponesse, Learning in the Carolingian Court and Cloister, 151-152.Walter Horn and Ernest Born, The Plan of St. Gall (Berkeley: University of California Press, 1979), 22-23. Horn and Born provide the most concrete evidence for the claim that the Secundae decreta was milder than the Primae decreta. Their argument surrounds two specific sections of the documents. The first involves the regulations on the use of baths, where they point to the Statuta Murbachensis which states that the use of baths is "prohibited... by the healthy monks, reserving this privilege to the sick" (Horn and Born, The Plan of Saint Gall, 22). They compare this with the Secundae decreta, in which they state that the synodists "did not retain the strictness of the prohibition of the preceding year, but liberalized it by the ruling: 'That the use of baths shall be left to the judgment of the prior"' (ibid., 22). What they fail to mention, however, is that the Primae decreta is also not as strict in this regulation as the Statuta Murbachensis. In the Primae decreta, it is noted "that baths generally be used only at the Nativity and the Easter of the lord nevertheless separately" (See Semmler, Primae decreta, chapter seven). In this oversight, we see the impact of
} 
Closer examination of the capitularies does not reveal any evidence of a two-stage reform. The contents of the two documents are markedly different, suggesting that the 817 capitulary is an extension of the regulations put forth by the Primae decreta. For instance, the abbots and monks place much emphasis in the Primae decreta on the need for monasteries to follow $R B$. The first three chapters dictate that upon return to their monasteries, abbots ought to read, discuss, memorize, and obey $R B$ with their monks. ${ }^{17}$ Yet, the Secundae decreta does not mention $R B$ whatsoever and instead begins by stating that monks must ask forgiveness of the prior if they make any noise in the refectory. ${ }^{18}$ This capitulum on proper behaviour within the refectory, however, is not mentioned in the Primae decreta. These differences in content suggest that the council of Aachen in 817 did not revise the decrees of the 816 capitulary texts, but rather proposed new monastic customs which they expected monks to follow in addition to those of the previous year.

The final assumption which Semmler's edition perpetuates is that the texts exert imperial authority due to the fact that the reform councils took place in the palace of

Semmler's chronological ordering of the texts. Horn and Born assume that the Statuta Murbachensis and the Primae decreta are the same text.

The second point, upon which Horn and Born build their argument in regards to the responsorial nature of the decrees, focuses on the role of the abbot and the reception of guests into the monastery. They note that the legislation of 816 "puts the abbots on the same footing with the monks 'in meal and in drink,' etc." (Horn and Born, The Plan of Saint Gall, 22). This is compared with the Secundae decreta where they state that "the capitulary of 817 drops the issue altogether," thereby implying that abbots were no longer required to be like their monks (ibid., 22). They also state that "the capitulary of 816 is quite specific about the fact that the abbot should not eat with the guests by the gate of the monastery... the synod of 817 eliminates this ruling also" (ibid., 22). However, both these arguments assume that the legislation of 816 is a response to the decree of 817 which is not explicit in the text. Furthermore, the difference in the Latin and the lack of continuity between the capitularies suggests that the decree of 817 is not merely amending the decree of 816 , but discussing independent issues altogether.

${ }^{17}$ Primae decreta, 457-458.

${ }^{18}$ Secundae decreta, 473. 
Aachen. ${ }^{19}$ This interpretation oversimplifies the relationship between the emperor, the palace, and imperial authority during the early ninth century, implying that they are synonymous of the same concept. Furthermore, Semmler's emphasis on imperial authority ignores any exertion of sacral authority within the capitularies, suggesting that monasticism was also subject to the power of the emperor.

Imperial authority in the Carolingian empire has recently been the subject of a great deal of discussion among historians. ${ }^{20}$ Matthew Innes argues that power shifted during the reign of Charlemagne from a complex network of social bonds to a hierarchical structure stemming from the emperor himself. ${ }^{21}$ He underscores that this shift transformed abbots and bishops into royal officials, suggesting that the church was also subject to the emperor and exerted imperial authority rather than any form of distinct sacral power. ${ }^{22}$ Building on this idea, Mayke de Jong argues that the emperor served not only as a secular ruler but also as a form of head bishop who was capable of "outbishoping" the men he appointed. ${ }^{23}$ Once again diminishing any independent sacral authority during this period, de Jong suggests that ecclesiastic figures drew authority from the Carolingian emperor. Thus, both de Jong and Innes indicate that the reformers

${ }^{19}$ Semmler, Introductio, CCM 1, 426: "Synodis a. 816 et 817 ab imperatore convocatis abbates monachique Aquisgrani in palatio imperiali ad consuetudines statuendas convenerunt. Quarum consuetudinum Benedictus capitulare institutum arbitrio submisit imperatoris."

${ }^{20}$ Although she is not writing on the subject of Carolingian monasticism, Rosamond McKitterick questions the general authority of Carolingian royal power and suggests that their rule was not universally accepted. She writes, "Carolingian rulership is based on sources designed to persuade us that Carolingian kingship was fully formed in 751. That it was then so formed is, however, and illusion." See McKitterick, “The Illusion of Royal Power," The English Historical Review 115, no. 460 (2000): 20.

${ }^{21}$ Matthew Innes, "Charlemagne's Government" in Charlemagne: Empire and Society (Manchester: Manchester University Press, 2005), 80-81.

22 Ibid., 85 .

${ }^{23}$ Mayke de Jong, "Charlemagne's Church" in Charlemagne: Empire and Society (Manchester: University of Manchester Press, 2005), 116. 
at the councils of Aachen required the emperor's direct approval in order to enforce the customs put forth in the capitulary texts.

In the capitularies of 816 and 817 , however, the role of the emperor differs from that which de Jong and Innes suggest. ${ }^{24}$ Aachen is certainly the meeting place for the Primae decreta, Secundae decreta, and arguably the Acta Praeliminaria as well, ${ }^{25}$ but that in itself does not confirm that the emperor personally oversaw the production of the capitularies. The Primae decreta states, for example, "the abbots... with their monks decreed... that these following capitula be maintained inviolable by the regular clergy."26 Although the reformers held their councils in Aachen, it remains the abbots-not the emperor-who communally with their monks ordered (decreverunt) the regulations put forth in the capitularies. This makes a clear difference from earlier Carolingian capitulary texts which explicitly state that the emperor was both involved with the composition of the documents and that he personally decreed their contents. ${ }^{27}$ The fact

\footnotetext{
${ }^{24}$ While I suggest that the capitularies of 816 and 817 do not appeal explicitly to any forms of imperial authority, this is not the case for the Admonitio Generalis, a capitulary which was written during Charlemagne's reign in 789. See the following section. The preface to the Admonitio Generalis is much more directly linked to the emperor himself, as it states, "quapropter nostros ad vos direximus missos, qui ex nostri [Charles'] nominis auctoritate una vobiscum corrigerent quae corrigenda essent" (Admonitio Generalis, ed. Boratius, 52). This passage would suggest that while Charlemagne himself might not have been setting the regulations, he certainly played a role in enforcing them throughout the kingdom. The authors stress no such imperial authority in the capitularies of 816 and 817 , nor do they mention any involvement of the missi. I contend, therefore, that a shift in authority occurs between 789 and 816 in which the emperor's direct name is not needed in order to enforce the capitula outlined at the synods.

${ }^{25}$ I suggest that the Acta praeliminaria were most likely written at Aachen due to the fact that the majority of the text is verbatim to the contents of the Primae decreta (although arranged in a different order), except that the Primae decreta includes a number chapters not included in the Acta praeliminaria. The similarity in content leads me to believe that the two documents are related.

${ }^{26}$ Primae decreta, ed. Semmler, 457: "abates cum quam pluribus una cum suis resedissent monachis haec quae subsecuntur capitula communi consilio ac pari voluntate inviolabiliter a regularibus conservari decreverunt."

${ }^{27}$ See Confirmation of Pippin III's Aquitanian capitulary, Memorandum for missi in Aquitaine (789), Admonitio Generalis, Capitulary of Frankfurt (June 794), Division of the realm: Thionville (806), Capitulary of Boulogne (811), MGH Cap. 1.
} 
that the authority of imperium originates from the religious council suggests that the meeting place of Aachen was not indicative of subjection to the emperor himself. ${ }^{28}$ Rather, the council selected this location for the synod because of the authority associated with Aachen as a Carolingian centre. ${ }^{29}$

The notion of the quasi-juridical nature of the capitularies extends futher in scholarship, seeing a sort of legal hierarchy to the capitularies and $R B$ itself. Walter Horn and Ernest Born contend that the capitulary texts addressed unforeseen aspects of monastic regulation and fixed other "superannuated or impractical" regulations. ${ }^{30}$ Similarly, Wallace-Hadrill suggests $R B$ "was expounded, difficulties and errors cleared up and some useful additions made."31 Wallace-Hadrill, Horn and Born, and others, construct the capitularies as a form of updated Rule, which was either too dated or insufficiently explicit enough about monastic practices for a ninth-century audience. Further, they imply that had $R B$ been written more recently or more clearly, the capitularies would not have been necessary. ${ }^{32}$

\footnotetext{
${ }^{28}$ The origins of Aachen's authority as a gathering point for ecclesiastic most definitely relates to the construction of the royal palace and the emperors' decision to remain permanently in that location. However, it is clear from the authors of the capitulary that Aachen held a form of power and authority separate from the emperor to the abbots and monks who gathered together in 816 . I suggest instead that the council selected this location for the synod not because they required Louis' approval, but rather because of the authority associated with Aachen as a Carolingian centre.

${ }^{29}$ I discuss the construction of authority in the capitularies of $816 / 817$ in the following section.

${ }^{30}$ Horn and Born, The Plan of Saint Gall, 20-21.

${ }^{31}$ J.M. Wallace-Hadrill, The Frankish Church (Oxford: Oxford University Press, 1983), 264.

${ }^{32}$ Wallace-Hadrill takes this argument further, as he later states that the capitularies were a form of "revised Rule" which "require explanation; so much so... that the influential Abbot Smaragdus of St Mihiel composed a very elaborate Commentary of the Rule." (Wallace-Hadrill, The Frankish Church, 264). Not only does this statement suggest that the legislation was simply an extension of $R B$, but it also implies that Smaragdus' Expositio was as well. I refute this argument in chapter three, 58-81.
} 
More recently, this trend of understanding the capitularies as a form of updated $R B$ has continued with Giles Brown noting that monks were to follow the rule "as revised and modified at Aachen" and Michèle Gaillard suggesting that the texts act "like given instructions for the application of the Regula sancti Benedicti. ${ }^{33}$ This definition has become authoritative-even appearing in the introduction to the standard version of the $R B$ used by Benedictines today. ${ }^{34}$

The interpretation of the texts as merely supplementary to $R B$, however, downplays the distinct monastic program which the capitularies assert and discourages analysis of the capitularies as independent Carolingian endeavours. Even a quick reading of the capitularies shows that there are significant contradictions between the contents of the capitularies and those of the $R B$. The initial tone and approach of the texts vary: the capitularies invoke a jussive sense demanding monks follow the capitula (e.g. capitula inviolabiliter a regularibus conservari decreverunt $),{ }^{35}$ whereas $R B$ emphasizes the importance of a monk's individual decision to submit and the labour involved in the decision to be obedient. ${ }^{36}$ Thus, while the capitularies assume obedience from monks, $R B$ implies that obedience is something which monks must learn to achieve over a long period of time.

${ }^{33}$ Giles Brown, "The Carolingian Renaissance," in Carolingian culture: emulation and innovation (Cambridge: Cambridge University Press, 1994), 25; Michèle Gaillard, D'une réforme à l'autre (816-934): Les communautés religieuses en Lorraine à l'époque Carolingienne (Paris: Publication de la Sorbonne, 2006), 154: "ne s'agit pas d'une règle mais de précisions données pour l'application de la règle de saint Benoît."

${ }^{34}$ Timothy Fry, et al., ed., $R B 1980$ (Collegeville: The Liturgical Press, 1981), 123.

${ }^{35}$ See Secundae decreta, 473 (cf. Primae decreta, 457).

${ }^{36} R B, 156$. I refer here to the prologue of $R B$ which states, "Ut ad eum per oboedientiae laborem redeas, a quo per inoboedientiae desidiam recesseras." In this passage, Benedict frames obedience as the labour of a monk. It is not something which is automatically done, as the capitularies suggest, but rather an ongoing occupation. 
Given the problematic assumptions of previous scholars, I suggest instead that the capitulary texts require an approach which assumes communal and anonymous authorship by abbots and monks, equal consideration of all the texts, and sacred rather than imperial authority. Furthermore, the capitulary texts are part of a distinct Carolingian monastic program which expresses interests and regulations separate from $R B$. Much of the scholarship on these capitulary texts attempts to establish their authority in external sources, either by associating the texts with imperial power or by framing the capitula as extensions of $R B$. In the following section, however, I explore how the texts exert an autonomous ecclesiastic authority which the authors of the capitularies attempt to exercise over Carolingian monks. Although Carolingians initially drew from papal authority by adopting their style of capitulary writing, by the ninth century the genre had taken on new meaning throughout the empire and asserted its own authority independent from Rome.

\section{SACRED AUTHORITY IN CAROLINGIAN CAPITULARY WRITING}

Be it known also to Your Paternity [Pope Zacharias] that Carloman, duke of the Franks, summoned me [Boniface] to him and requested me to bring together a council in the part of the Frankish kingdom which is under his rule... The Franks, according to their elders, have not held a council for more than eighty years, nor have they had an archbishop or established or restored anywhere the canon law of the Church. ${ }^{37}$

${ }^{37}$ Die Briefen des heiligen Bonifatius and Lullus, MGH ES I, ed. Michael Tangl (Berlin: 1916), letter 50, 82: "Notum similiter sit paternitati vestrae, quod Carlomannus dux Francorum me arcessitum ad se rogavit, ut in parte regni Francorum, quae in sua potestate, synodum cepere congregare... Franci enim, ut seniores dicunt, plus quam per tempus octuginta annorum synodum non fecerunt nec archiepiscopum habuerunt nec aecclesiae canonica iura alicubi fundabant vel renovabant." Translation adapted from Ephraim Emerton, trans., The Letters of Saint Boniface, ed. Thomas Noble (New York: Columbia University Press, 2000). 
In this letter to Pope Zacharias in 742 , Boniface, an Anglo-Saxon cleric, paints a dim picture of the Carolingian church, suggesting that the Franks had drifted away from the practices established and followed in Rome. He indicated that "adulterous and vicious" clerics exploited the church for secular purposes, and emphasized the need for regular synods and uniform regulation of ecclesiastic offices. Noble warns that this image of the church as "virtually collapsed and desperately in need of reform" is an exaggeration which Boniface utilizes in order to bolster support for his own ecclesiastic program. ${ }^{38}$ However, the passage continues to demonstrate an early use of ecclesiastic councils and capitulary writing in order to craft and exert sacral power. Boniface indicates that Carloman, as a secular lord, requested the assistance of a sacred man to organize and instruct the ecclesiastics of his empire. This suggests that while secular rulers may have had the power to initiate change within the sacred sphere, they were illequipped to use their own authority in order to alter sacred customs.

Misconceptions surrounding Carolingian capitulary writing have had a tremendous impact on the study of eighth and ninth-century monasticism. Twentiethcentury political historians often use ecclesiastic capitularies in order to bolster support for their assertions that new monarchical sovereignty under great Carolingian emperors and emperors brought about a cultural and intellectual renaissance throughout western Europe. ${ }^{39}$ However, a closer examination of the capitulary texts reveals that an increasingly autonomous form of sacred authority was in the process of developing throughout the Carolingian period. This independence is significant in the context of

\footnotetext{
${ }^{38}$ Thomas Noble, ed., "Introduction," in The Letters of Saint Boniface (New York: Columbia University Press, 2000), xvii.

${ }^{39}$ See chapter one, 8-29.
} 
monastic interaction, as the authors of the capitularies construct their own independent monastic program and present new attitudes toward contact with outsiders.

While an abundance of capitulary texts separate Boniface's mid eighth-century plea for Frankish ecclesiastic regulations from the 816 and 817 capitularies, his particular appeal to papal authority is significant in the context of the later capitularies. His desire to acknowledge the authority of Rome on ecclesiastic matters illustrates a trend of negotiating between traditional ecclesiastic texts and contemporary Carolingian ideas surrounding the regulation of the church in the Frankish empire. Matthew Ponesse suggests that this negotiation reaches beyond capitulary composition itself and characterizes a major facet of broader Carolingian writing. He asserts that authors from this period "might rest on the authorities of the past, but recast them in such a way that [they] produce new and original ideas." ${ }^{40}$ Extending this argument to include the Carolingian capitularies, therefore, I suggest that sacred ecclesiastic leaders renovate old styles in new ways, such that they were independent and innovative texts.

The authors of the Carolingian capitularies included references to Roman sources in their writing in order to establish their authority within new texts. In the case of the ecclesiastic capitularies dating back to the mid-eighth century, authors refer predominantly to $R B$ and a collection of canonical texts entitled the Dionysio-Hadriana. ${ }^{41}$ Both of these texts have clear connections with Rome, ${ }^{42}$ suggesting that early Carolingian

\footnotetext{
${ }^{40}$ Matthew Ponesse, "Learning in the Carolingian Court and Cloister: Compilation and Innovation in the writings of Smaragdus of St Mihiel" (Ph.D. diss., University of Toronto, 2005), 208.

${ }^{41}$ References to both texts appear in the Admonitio Generalis, however, Boniface also refers to $R B$ earlier in his letters.

${ }^{42}$ In regards to the connection between $R B$ and Rome, $R B$ states, "the Rule of Saint Benedict was found suitable especially [because] its liturgical provisions reflected a "Roman" practice" (117). Furthermore, they also note that Charlemagne received a copy of $R B$ from Montecassino which he
} 
ecclesiastics understood authority as stemming from the papacy rather than the

Carolingian church itself.

Whereas Boniface wholly appeals to Roman authority in the matter of setting regulations for ecclesiastics, later capitularies from Charlemagne's reign suggest that a shift was occurring in conceptions surrounding ecclesiastic authority. The authors of the Admonitio Generalis, a capitulary text written in 789 , divide the long text into two parts.

The first capitulum orders:

To all. There are people who are excommunicated for proven faults by their own bishop and yet are still accepted into the community without consideration by other ecclesiastics or laymen. It is entirely forbidden that this happen by the council of Nicea, likewise by the council of Chalcedon and also by the councils of Antioch and Sardica. ${ }^{43}$

This excerpt is typical of the first fifty-nine capitula, in that it first paraphrases a regulation and then states the council(s) to which it refers in the Dionysio-Hadriana collection. While faithfulness to the exact text of the Dionysio-Hadriana varies between capitulum, ${ }^{44}$ what is most significant in the passage are the explicit references to the

considered 'authentic.' He housed this copy of $R B$ at Inde, the monastery built next to Aachen under the abbacy of Benedict of Aniane (122). The Dionysio-Hadriana relates more specifically to the papacy and is a compilation of canonistic materials. Originally called the Dionsyiana after the monk who compiled the texts, the Dionysio-Hadriana includes additions made by Pope Hadrian in the eighth century. A copy of this text was sent to Charlemagne before 789. See Abigail Firey, "The Collectio Dionysiana,"

http://www.rch.uky.edu/CCL/article-dionysiana.html (Accessed Jan. 25, 2009).

${ }^{43}$ Admonitio Generalis, MGH Cap. 1, 54: “Omnibus. Sunt enim aliqui, qui culpis exigentibus ab episcopo proprio excommunicantur et ab aliis ecclesiasticis vel laicis praesumptuose in communionem accipiuntur: Quod omnino sanctum Nicenum concilium simul et Calcidonense necnon atque Antiochenum, atque Sardicense fieri prohibent." All translations of capitulary sources are my own.

${ }^{44}$ This particular capitulum appears to be fairly close in meaning the three councils it refers. The capitulary from the Council of Nicea states, "De his qui communione privantur, seu ex clero, seu ex laico ordine, $a b$ episcopis per unamquamque provinciam, sententia regularis obtineat: ut hi qui abjiciuntur ab aliis, ab aliis non recipiantur" (Dionysio Hadriana, col. 148C). The Sardican Council states, "Osius episcopus dixit: Quod me adhuc movet reticere non debeo, si episcopus, qui forte iracundus (quod esse non debet) cito et aspere commovetur adversus presbyterum, sive diaconum suum, et exterminare eum de Ecclesia voluerit, providendum est ne innocens damnetur, aut perdat communionem" (Dionysio Hadriana, cols. 181B-181C) 
church councils. Although this text is undoubtedly an expression of Carolingian ecclesiastic regulation in the manner in which it rearranges and states the capitula, it appeals to the authority of the Rome through the overt references to canonical texts. Thus, the first fifty-nine capitula exercize Roman authority rather than exert an independent form of Carolingian command.

There is a shift which occurs in the sixtieth capitulum, where the text warns readers about the dangers of not following the first fifty-nine regulations and then states, "likewise here are some other capitula which have been considered useful (utilia) by us to join to this preceding reminder." ${ }^{45}$ Following this statement are twenty-two capitula which the authors do not tie back to the Dionysio-Hadriana. The suggestion that the second half of the Admonitio Generalis adds extra "useful" articles does not do justice to the sudden assertion of independent Carolingian authority in regulating ecclesiastic affairs. Each of the subsequent capitula are much longer than the first fifty-nine, often citing scriptural passages within the first line of the texts. These scriptural references, albeit another form of external authority, break with the previous trend of selecting, paraphrasing, and reordering particular articles of the Dionysio-Hadriana.

By contrast, the capitulary documents of 816 and 817 make no explicit reference to any external text and instead base their own authority in custom. For instance, the preface to the Statuta Murbachensis introduces the capitula by noting:

Certain things have been brought forward in that place following the authority of the rule [of Saint Benedict], but certain things have also been brought forward by

\footnotetext{
${ }^{45}$ Admonitio Generalis, MGH Cap. 1, 57: "Sunt quoque aliqua capitula quae nobis utilia huic praecedenti ammonitione subiungere visa sunt."
} 
experience (usu) and custom (consuetudine). The custom, if it has not been corrupted by some fault, is able to be blamelessly upheld like canonical law. ${ }^{46}$

Unlike the Admonitio, the authors of the Statuta Murbachensis imply that a portion of the proposed regulations stem from experience, legitimized by tradition. However, it is evident that the authors also anticipate some uncertainty surrounding the role and authority of the capitula, as they make a point of distinguishing between canon law and custom and attempt to assert that they ought to hold the same sway over Carolingian audiences. This effort to emphasize the separate authority of the capitula adds credence to the suggestion that the conception of the ecclesiastic capitularies, and therefore the authority of the Carolingian church itself, was undergoing a shift in the early ninth century. It no longer mattered that the capitula did not cite canon law passages as in the Admonitio because the authors of the capitularies expected monks to comply with their regulations as much as those sent from Rome. ${ }^{47}$

Whether or not all Carolingian monks agreed with the Aachen capitulary texts, this independent assertion of authority is significant because it demonstrates that the authors of the capitularies were consciously constructing a monastic program which they understood as traditional but innovative particular to their circumstances. Less frequent direct citations of Roman sources indicates that Carolingian monks and abbots

\footnotetext{
${ }^{46}$ Statuta Murbacensis, 441: "quaedam ibi secundum auctoritatem regulae, quaedam vero usu et consuetudine prolata sunt, quae consuetudo, si aliquot vitio corrupta non fuerit, pro lege regulari inculpate retineri poterit." The interpretation of "pro lege regulari" is difficult to decipher. I have opted to suggest that the authors intended both canon law and the capitula to be upheld in an equal manner, rather than to suggest that these capitula were to replace canon law.

${ }^{47}$ It is also significant to emphasize again that the Statuta Murbachensis is the only capitulary text from 816 and 817 which bothers to even address the authority of the capitularies themselves in the preface. In each of the other capitularies, there either is no preface (Acta praeliminaria) or else the authors simply assert that abbots and monks decreed (decreverunt) the regulations.
} 
understood their own synods as being equal in authority to those of Roman background. ${ }^{48}$ Thus in the capitularies from 816 and 817 , the authors no longer bother to explain or justify the regulations which they order. As I discuss below, this newly established sacred authority in the capitulary sources corresponded with the desire to establish clear sacred roles within the Carolingian empire.

\section{CLOISTERED INTERACTION AND THE PLACE OF MONKS}

In 811, a document calling for a synod at Aachen demanded that bishops, abbots, and counts congregate separately and that they consider "the extent to which a bishop or abbot ought to involve himself in secular matters and a count or other layman in ecclesiastical affairs. ${ }^{.49}$ This proposed restructuring of the synods underscores that the formation of distinct lay, episcopal, and monastic offices was highly important to the individuals involved in early ninth-century capitulary production. They debated the respective authority of each group and distinguished particularly between sacred and secular roles. Perhaps responding to this plea for segregated offices, the capitularies of 816 and 817 express particular concern for outlining the monastic way of life.

Addressing only the regular clergy, the abbots and monks who gathered at Aachen present an attempt to construct unity across the empire through common regulations.

\footnotetext{
${ }^{48}$ This period of transition in ecclesiastic authority which I am suggesting corresponds with Noble's theory that the relationship between the Carolingian empire and the Republic of St. Peter changed around the year 800 when the Pope crowned Charlemagne Holy Roman Emperor. Although Noble's emphasizes that the Republic was autonomous from the Frankish kingdom and asserted its own secular authority, in the context of sacred authority it is necessary to emphasize that the Frankish church began to assert authority separate from Rome. See Noble, "The Republic and the Franks," 277-324.

${ }^{49}$ Capitula tractanda cum comitibus episcopis et abbatibus, MGH Cap. 1, ed. Alfred Boretius (Hanover: 1883), chapters 1 and 5, 161: "in quantum se episcopus aut abbas rebus secularibus debeat inserere vel in interveniendum comes vel alter laicus in ecclesiastica negocia." This synod for which they are laying out questions may in fact have been the synods of Aachen in 816 and 817.
} 
Yet, while the form of the capitularies certainly emphasizes an exclusive monastic role, the content of the capitularies themselves affirm this distinction. On the subject of caring for monastic estates removed from the physical site of the monastery, the tenth capitulum of the Statuta Murbachensis adopts a more personal tone as verbs briefly shift from first person plural to first person singular. The text reads:

God, who is privy to my heart, is the witness that it is not voluntarily but unwillingly that I am involved in earthly occupations, in that he sometimes frees us from the duty to "Caesar" ${ }^{, 50}$ to which we are subject, so that we may at other times be free to do safely what things are of God. ${ }^{51}$

The emphasis which the authors place on this line by shifting to first person singular hints at the importance of the statement within the broader context of the work. Although this passage may appear simply to express the author's weariness at being involved in secular affairs, in fact, it defines a major facet of the monastic profession. ${ }^{52}$ The authors underscore that a monk ought to desire above all else to serve God, while not neglecting to take into account what is necessary to get God's work done. However, rather than

\footnotetext{
${ }^{50}$ The author of the Statuta refers here to the vow of fidelity promised to the Carolingian emperor. The Capitulare missorum generale 802, outlines that "he [Charlemagne] has ordered that every man in his entire realm, whether ecclesiastic or layman, each according to his vow and way of life, who has previously promised fidelity to him in the name of the emperor is now to make that promise in the name of Caesar." See Capitulare missorum generale 802, MGH Cap. 1, ed. Alfred Boretius (Hanover: 1883), chapter 2, 92: "Precepitque, ut omni homo in toto regno suo, sive ecclesiasticus sive laicus, unusquisque secundum votum et propositum suum, qui antea fidelate sibi regis nomine promisissent, nunc ipsum promissum nominis ceasaris faciat."

${ }^{51}$ Statuta Murbacensis, 445: "deus est testis qui conscius est cordis, quod in terrenis occupationibus non sponte sed invitus inhereo, qui quandoque a tributis caesaris nos absoluat quibus obnoxii sumus, ut securius quae dei sunt quandoque nobis agere liceat."

${ }^{52}$ Within the same passage, the author refers to the monastic occupation directly himself. $\mathrm{He}$ states, "going round the estates frequently is never done by us because another hindrance of our occupation tires us." Reminiscent of Ardo's mention of the monastic profession (professio), the capitulary implies that visiting monastic estates, although they are affiliated with the monastery itself, remains beyond the scope of the monastic occupation (occupatio). Although the monks still must visit and care for the estates, this responsibility falls outside the boundaries of the cloister and thus beyond divine duty. See Statuta Murbachensis, chapter 10, 445: "frequentationis circumitio inter villas ideo numquam fit a nobis, quia aliud inpedimentum nostrae occupationis nos fatigat quia aliud inpedimentum nostrae occupationis nos fatigat."
} 
defining precisely what this work entails, they oppose divine work with earthly occupations-something they associate directly with the Carolingian emperor through reference to the vow of fidelity in the name of Caesar. ${ }^{53}$ Thus, the authors juxtapose the monastic profession with duty to the emperor and suggest that they do not overlap. ${ }^{54}$

The Aachen capitularies further segregate the monastic vocation from other professions by linking it to the physical place of the monastery, implying that divine work takes place exclusively within the cloister. On the subject of caring for the monastic estates, a capitulum in the Primae decreta notes:

That [abbots] should not travel between estates unless necessity compels them nor commit their own monks to be those houses' guardians. And if it is necessary that they go to those places, they must quickly return to their own monastery upon having concluded the necessary business. ${ }^{55}$

Here, by underscoring the need for a prompt return to the cloister, the authors highlight the importance of place in connection with the monastic vocation. Monks and abbots ought only to leave the monastery for brief intervals of time when absolutely necessary, as the opus Dei takes place within the structure of the monastery itself. Despite the fact

\footnotetext{
${ }^{53}$ This representation of the emperor also adds weight to my discussion in the previous section of this chapter that the ecclesiastic capitularies of 816 and 817 exert a form of authority distinct from imperial authority. See page 40 .

${ }^{54}$ This capitulum also makes a clear distinction between the monastic profession and the curas episcopates. The author(s) indicates that it is both the imperial orders and the cares of the bishop which hinder their ability to perform the divine office. See Statuta Murbachensis, chapter 10, 445.

${ }^{55}$ Primae decreta, ed. Semmler, chapter 24, 464: "Ut villas frequenter et nisi necessitas coegerit non circumeant neque suis illas monachis custodiendas committant. Et si eos ire ad eas necessitas fuerit expleto necessitates negotio ad sua mox monasteria redeant." The reason I make a connection here between the contents of the Statuta Murbachensis and the Primae decreta is due to a similarity in the Latin between the two statements. The first line of capitulum ten in the Statuta reads, "ut abbates frequenter villas non circumeant nisi causa necessitates nec fratribus illas custodiendas committant" (Statuta Murbachensis, chapter 10,445). Meanwhile, the first line of capitulum twenty-four in the Primae decreta states, "Ut villas frequenter et nisi necessitas coegerit non circumeant neque suis illas monachis custodiendas committant" (464). Although the text is not completely identical, I see enough similarity between the two passages to assume that they are drawing on the same idea in the subsequent text of each capitulary.
} 
that the estates may even support the monastery, the authors of the capitularies emphasize the need for monks to remain within the cloister in order to fulfil the monastic occupation.

Also connecting the monastic vocation to the place of the cloister is a capitulum in the Secundae decreta which orders, "that no servant or secular cleric be accepted in the monastery for the purpose of living unless he wishes to be a monk."56 The use of the gerundive in this instance is significant, as the authors specify that this does not restrict lay people or clerics from entering the cloister. Rather, the authors assert that only once an individual desires to live within the confines of the cloister more permanently must he be a monk, implying that others remain in the cloister less permanently. According to the authors of the capitularies, therefore, those who dwell within the place of the monastery must follow monastic customs.

This heightened concern of the place which monks occupy contrasts with an anecdote related at the beginning of the Admonitio Generalis. In this earlier capitulary, the scribe invokes the voice of Charlemagne, who addresses ecclesiastics:

O shepherds of Christ's church, leaders of his flock and the most bright lights of the world, would that you strive to lead the people of God into the pastures of the eternal life by your watchful care and your attentive advice, and be sufficient to carry back on your shoulders the wandering sheep to the firm walls of the Church by encouraging words or by the example of your good works, lest, God forbid, the devious wolf devour those transgressing canonical rule or going beyond the paternal traditions of the universal councils. ${ }^{57}$

\footnotetext{
${ }^{56}$ Secundae decreta, chapter 2, 473: "Ut nullus plebeius aut clericus secularis in monasterio recipiatur ad habitandum nisi voluerit fieri monachus."

${ }^{57}$ Admonitio Generalis, $M G H, 53:$ "O pastores aecclesiarum Christi et ductores gregis eius et clarissima mundi luminaria, ut vigili cura et sedula ammonitione populum Dei per Pascua vitae aeternae ducere studeatis, et errantes oves bonorum operum exemplo seu adhortatione humeris intra ecclesiasticae firmitatis muros reportare satagite, ne lupus insidians aliquem canonicas sanctiones transgredientem vel paternas traditiones universalium conciliorum excedentem, quod absit, inveniens devoret."
} 
While this passage equates ecclesiastics instructing lay society with shepherds looking after a flock of sheep, the imagery evokes the need to return those who err back within the firm walls of the church. Walls here are metaphorical structures used to distinguish social groups: the boundary of ecclesiastic / profane space is demarcated as firmly as the claustral limits. The authors present the empire as a church and suggest that ecclesiastics watch over secular society, and bring them to the refuge of the Church when necessary. In this capitulary, it is evident that authors were less concerned with associating the monastic vocation particularly with the monastery itself, and instead imply that all monastic roles occupy a form of cloistered position.

This emphasis on place within the 816 and 817 capitularies is important to highlight, but it does not imply that monks were to have no contact with the outside world. In fact, the authors encourage interaction in regulated manners. One of the most repeated capituli surrounds the reception of guests within the monastery. Appearing in a similar form in all capitularies from 816 , the authors of the Primae decreta order:

That abbots or any of the brothers should not eat at the door of the monastery with guests (hospitibus), but should offer every courtesy in eating and drinking within the refectory. Nevertheless, let that actual guest be contented with the measure of food and drink which the other brothers receive. Indeed if the abbot wishes to increase somewhat the usual measure of the brothers and themselves because of the guest, it remains in their own power. ${ }^{58}$

\footnotetext{
${ }^{58}$ Primae decreta, ed. Semmler, chapter 25, 464-465: "Ut abbas vel quispiam fratrum ad portam
} monasterii cum hospitibus non reficiat, in refectorio autem omnem eis humanitatem manducandi ac bibendi exibeat. Ipse tamen ea cibi potusque mensura contentus sit quam reliqui fratres accipiunt. Si vero propter hospitem voluerit ad solitam mensuram fratribus sibique aliquid augere in sua maneat potestate." There is a similar capitulum in the Acta praeliminaria which is nearly verbatim to this excerpt from the Primae decreta, however, it does not include the line which increases the amount of food and drink at the abbots discretion.

The use of the word hospitibus to describe guests renders the authors' meaning somewhat unclear in this passage as to whether they are referring to secular guests or all guests. In other ninth-century monastic writing, hospitibus most commonly refers to secular guests (see chapters 53 of $R B$ and Smaragdus' Expositio). This might imply that the authors concern for receiving visitors in this specific manner refers only to secular guests, not necessarily other monastic or ecclesiastic guests. 
This capitulum affirms that the authors of the capitulary emphasized that interaction ought to occur within the cloister, rather than on the threshold of the monastery at the door. The potential to increase the amount of food which the brothers receive because of the guest transforms the arrival of the foreign bodies within the cloister into something of a celebration. ${ }^{59}$ This capitulum, therefore, reaffirms that interaction does not threaten the claustration of monks and suggests instead that monastic communities ought to desire contact with outsiders. ${ }^{60}$

The capitulary further criticizes inhospitable monks, emphasizing that catering to the needs of outsiders is a key aspect of the monastic life. Thus, it is not interacting with the outside world but rather moving outside the cloister which the authors of the capitularies caution strongly against. We have already seen a desire in these texts to restrict monks from moving beyond the cloister walls to care for the estates affiliated with the monastery. Further to this regulation, the authors also express concerns over monks ever travelling alone and assert that abbots must send monks out in pairs. ${ }^{61}$ This restrictive attitude toward travelling outside the cloister relates to concerns in earlier capitularies over wandering monks (vagabundi). As $R B$ particularly reprimands unlawful

\footnotetext{
${ }^{59}$ On the same subject in the Statuta Murbachensis, the authors expand upon this capitulum and write, "the brothers also may rejoice together somewhat on the arrival of brothers and may relax a bit the harness of abstinence." Here, the Statute specifies that the brothers are particularly to rejoice upon the arrival of other monks. Statuta Murbacensis, chapter 23, 448: "fratres etiam in adventu fratrum aliquatenus congaudeant et abstinentiae frena relaxant."

${ }^{60}$ Another capitulum in the Secundae decreta renders this passage more difficult to interpret, as it states, "Ut laici in refectorium causa manducandi vel bibendi non ducantur." It is odd that three of the capitularies emphasize that guests may enter the refectory to eat, while this one indicates that the laity may not be led into the refectory for the purpose of eating or drinking. I would suggest that there is a difference between a guest who is a lay person visiting the monastery, and a lay person visiting the monastery simply to eat. More research is needed here in order to understand the differences between hospes and laicus. Secundae decreta, chapter 14, 477.
}

${ }^{61}$ See Primae decreta, chapter 13, 460: "ut soli videlicet sine alio fratre in via non dirigantur." 
wandering, ${ }^{62}$ the authors of the capitularies recast arguments against monastic itinerancy in order to underscore their program of tying the monastic vocation to the place of the monastery. ${ }^{63}$

Central to the monastic program which the authors of the 816 and 817 capitularies construct, therefore, is the connection they establish between the monastic profession and the physical site of the monastery. To be a monk, they assert, is to live within the cloister. Thus, they establish a firm boundary between the cloister and the outside world and discourage monks from travelling beyond the walls of the monastery. Yet, this boundary is to a certain extent one-way, as the authors do not suggest that monks must be secluded from the outside world. Contact with other monks, ecclesiastics, and secular guests was not only welcomed, but even celebrated within the refectory of the monastery. For this reason, it is necessary to rethink how these Carolingian writers conceived of claustration. ${ }^{64}$ Although previous scholarship underscores the connection between claustration and seclusion, it is evident that the authors of the capitularies do not establish an oppositional relationship between claustration and interaction. Rather, a monk and especially abbots could interact with the outside world while remaining cloistered within the monastery without being in any way at fault.

${ }^{62}$ See $R B$ 1980, chapter 1, 170-171. Although $R B$ calls wandering monks gyrovagus, the term as is used in the Regula Magistri, they clearly denounce the same practice of monastic itinerancy. For further history on the term see Maribel Dietz, "Monastic Rules and Wandering Monks," in Wandering Monks, Virgins, and Pilgrims: Ascetic Travel in the Mediterranean World, A.D. 300-800 (Pennsylvania: Pennsylvania State University Press, 2005), 69-105.

${ }^{63}$ It is also significant to note that the capitularies do not attempt to regulate correspondence. If contact with the outside world (be it the secular, ecclesiastic, or monastic worlds) was problematic, this is one area in which I would expect to see some form of regulation. As conversing with other bodies does not require departure from the cloister itself, however, I suspect that it was not a concern.

${ }^{64}$ Understanding how Carolingians conceived of claustration is a task which extends beyond the scope of this project. I intend to explore this in future research. 
CONCLUSION

It is important to underscore Ardo's statement regarding how the capitulary texts of $816 / 817$ restored all monasteries "to the form of unity as if they were taught by one teacher in one place," which I cited at the beginning of this chapter. ${ }^{65}$ The capitularies were certainly concerned with unifying Carolingian monasticism, to the point that they assert that there ought to be only one monastic profession. Ardo highlights how this one order followed $R B$. Yet, while the capitularies themselves demand that all monks memorize and follow $R B$, the texts also command their own authority and construct an independent monastic program. This sacred authority stems from the within the Carolingian church, as abbots and monks increasingly began to assert their own monastic regulations.

Crucial to this new monastic program was the notion of the space of the monastery, which the authors constructed as an essential component of claustration. Just as the authors of the capitularies attempted to craft a monastic profession which was distinct from ecclesiastic and secular roles, they also sought to construct the monastery as a distinct house for monks. Thus, the physical reality of where monks lived mirrored the separate relationship they shared with other members of Carolingian society through synodal decrees. It is important not to construe this emphasis on place and claustration as indicating that capitularies desired to halt all interaction between sacred and secular communities. Rather, it regulated the manner in which interaction might occur.

${ }^{65}$ Ardo of Aniane, Vita Benedicti Anianensis, cols. 0377B-0377D: "cunctaque monasteria ita ad formam unitatis redacta sunt, ac si ab uno magistro et in uno imbuerentur loco." 
The following chapter discusses how another Carolingian monastic writer, Smaragdus of Saint Mihiel, constructs a very different type of claustration, which emphasizes an interior monastic space. In contrast to the capitularies, he presents a different program than that asserted in the capitularies. This will contribute to the deconstruction of the traditional narrative of reform which runs throughout much of the previous scholarship and suggests instead that many different monastic authorities asserted different monastic programs in the early ninth century. 


\section{CHAPTER THREE}

\section{INTERIOR CLAUSTRATION AND ACTIVE HOSPITALITY IN SMARAGDUS' EXPOSITIO IN REGULAM SANCTI BENEDICTI}

Shortly after the synods of Aachen and the composition of the capitulary texts

from 816 and 817, abbot Smaragdus of Saint-Mihiel wrote his Expositio in Regulam

sancti Benedicti. ${ }^{1}$ The work begins with a metrical preface, in which Smaragdus

addresses his monks directly. He writes:

Whoever prefers to ascend to the eternal kingdom, Ought to climb to the starry heaven in mind;

To seek the path of life by means of pious religion

To climb where the swift golden rule may prevail

For well-formed monks the Rule of our holy Father Benedict

Is an even, pleasant and broad way;

But for boys and beginners it is harsh and narrow...

This is a holy pellucid pathway to the sky, Upon which they wish to seize the blessed fortress of God. ${ }^{2}$

\footnotetext{
${ }^{1}$ Smaragdus of Saint Mihiel, Expositio in Regulam sancti Benedicti, 835D. Although the precise dating of this text remains unknown, Smaragdus certainly wrote it after 816 as he refers directly to the synods twice in the text. The first mention appears in chapter fifteen: "Quamvis beatus Benedictus a Pentecoste usque ad caput Quadragesimae, cum sex posterioribus psalmis jubeat ad nocturnas dicere Alleluia, placuit tamen synodo in Francorum regno congregatae, ut sicut Romani principes Ecclesiae in Septuagesima dimittunt Alleluia, ita dimittant et monachi qui in eodem sunt regno constituti" (ibid.). The second mention in chapter fifty-three reads: "Sed modo ab episcoporum, abbatum, et caeterorum Francorum magno concilio salubre inventum est concilium, ut pro sua et fratrum custodia habeat in communi refectorio mensam, ubi quando adfuerint cum hospitibus, quando vero defuerint, cum quibus voluerit, reficiat coram fratribus" (ibid., 892C) The lack of mention of reference to the synod of 817 may suggest that the text was in fact written between the composition of the two sets of capitulary documents. However, as Smaragdus is inconsistent in his mention of the capitula and does not always refer to them when approaching pertinent chapters of $R B$, this is ambiguous. We may only conclude that Smaragdus was aware of the capitularies and thought them important enough to reference in his Expositio. I discuss Smaragdus' connection to the capitularies further in this chapter.

${ }^{2}$ Smaragdus of Saint-Mihiel, Expositio, col. 689B: "Quisquis ad aeternum mavult conscendere regnum, / Debet ad astrigerum mente subire polum; / Religione pia vitae perquirere callem / Scandere quo valeat aurea regna celer / Est monachis sancti Benedicti Regula Patris / Perfectis palma suavis et ampla via, / Aspera sed pueris nec non tironibus arcta... / Haec est sancta via praelucida semita coeli, / Carpere quam cupiunt castra beata Dei." All translations of Smaragdus' Expositio are adapted from David Barry, trans., Commentary on the Rule of Saint Benedict (Kalamazoo: Cistercian Publications, 2007).
} 
In this passage, Smaragdus instructs monks to conceive of their vocation as an interior journey to salvation. Although he asserts that this journey takes place within the minds of monks, he employs corporeal, itinerant language in order to describe the expedition. He writes that a monk must climb (scandere and subire) the path (via, callem, semita) to ascend (conscendere) to God. This was a metaphorical path which monks must follow in order to reach "the blessed fortress of God."

A monastic program which adopts an itinerant discourse and transforms it from deviant activity ${ }^{3}$ into a positive phenomenon seems at odds with the Aachen capitulary decrees. The capitulary texts approach the subject of itinerancy with caution, as they defined monks through their physical presence within the cloister. By defining the monastic profession in this manner, Smaragdus detaches the idea of claustration from the physical walls of the cloister and represents it as an interior journey. This interior definition of claustration has a profound impact on the interpretation of interaction between secular and sacred communities, as locating piety in a mental state not a physical condition enables a monk to move more freely outside the monastery and engage with the secular community as well as other ecclesiastics. The interior space of the monk becomes the locus of the sacred, allowing him to move outside the sacred place of the cloister.

The purpose of this chapter is to examine how Smaragdus conceives of monks' interaction with the world outside the cloister. He develops ideas on this theme through an exploration of the relationship between the interior contemplation and exterior actions

\footnotetext{
${ }^{3}$ For more information on the history of itinerancy as a deviant activity, see Maribel Dietz, Wandering Monks, Virgins, and Pilgrims: Ascetic Travel in the Mediterranean World, A.D. 300-800 (Pennsylvania: Pennsylvania State University Press, 2005).
} 
of a monk. I argue that he also portrays interaction as positive and encourages contact as an essential component of a monk's spiritual quest. In order to demonstrate this, I first examine Smaragdus' role within the monastic reform movement and his attitude toward the capitularies, then explore his emphasis on the interiority of monasticism, and finally I analyze Smaragdus' presentation of interaction and reception within the Expositio.

\section{RECONSIDERING SMARGDUS' ROLE AS REFORMER}

Early twentieth-century scholarship on Smaragdus concentrated largely on basic issues of chronology and background: ${ }^{4}$ That the abbot was likely either born or educated in Spain and writing roughly between the years 809 and $826 .^{5}$ With basic questions answered, more recent scholarship has turned to interpreting Smaragdus' texts—seeking in them evidence for better understanding Carolingian monasticism and politics during the early ninth century. ${ }^{6}$ Prevalent in most scholarship is the portrayal of Smaragdus as an advocator of the Aachen monastic reform movement. ${ }^{7}$

${ }^{4}$ Max Manitius suggested in contrast that Smaragdus might have Irish origins based on an analysis of the grammatical style in the Commentary on Donatus. This idea was taken up in subsequent scholarship including, M.L.W. Laistner, "The Date and Recipient of Smaragdus' Via Regia," Speculum 3, no. 3(1928): 392-397; Adele Kibre, Prolegomena to the Unpublished Text of Smaragdus' Commentary on Donatus (Chicago: 1930); Jean Leclercq, La voie Royale, Le Diadème des Moines (La Pierre-qui-vire: 1949). However, scholars have now agreed that the abbot was either born or at least educated in Spain. Bernard Bischoff suggested that Smaragdus' use of classical Latin grammar styles and language was more in line with Visigothic or southern French styles in the early ninth century. Fidel Rädle has added weight to this conclusion by outlining the very close agreement of known Visigothic writings with Smaragdus' texts. See Bischoff, "Muridac doctissimus plebis, ein irischer Grammatiker des IX. Jahrunderts," Celtica 5 (1960): 40-44; Fidel Rädle, Studien zu Smaragd von Saint-Mihiel (München: Wilhelm Fink Verlag, 1974); B. Löfstedt, L. Holtz, and A. Kibre, "Les origines méridonionales de Smaragde," Liber in partibus Donati, CCCM 68 (1986), ix-xiii.

${ }^{5}$ Prior to his composition of the Expositio, which was after 816, Smaragdus wrote two other commentaries on the Psalms and Donatus, a treatise on the procession of the Holy Spirit, a book on the proper conduct of emperors (via regia), a book of patristic readings, and a book on monastic spirituality (Diadema monachorum).

${ }^{6}$ See Jean Leclercq, "Smaragdus," An Introduction to the Medieval Mystics of Europe, ed. Paul Szarmach (Albany: State University of New York Press, 1984), 37-52; Alain Dubreucq, "Smaragde de 
Although it is common to find Smaragdus' name joined to that of Benedict of Aniane and Louis the Pious, the depiction of Smaragdus' level of involvement with the reform varies in each study. For instance, H. Peltier states that Smaragdus played an active role in the councils at Aachen in $816 / 817$, and Terrence Kardong argues that Smaragdus attended the councils, approved of the capitularies, and incorporated the ideologies of the reform into his own writing. ${ }^{8}$ Holtz extends this characterization, suggesting that the abbot was a missi of the emperor despite no apparent evidence. ${ }^{9}$ In fact, the little extant information about Smaragdus outside his own writings—something which has hindered any complete account of his life and career-has meant that the complex body of his work provides the sole means to establish his ideas and interests. ${ }^{10}$ Scholars, therefore, have turned to Smaragdus' writing in order to obtain a sense of how aware or approving he was of the capitulary texts.

Saint-Mihiel et son temps: Enseignment et bibliothèques à l'époque carolingienne," Mélanes de la Bibliothèque de la Sorbonne 7 (1986): 7-36; Terrence Kardong, "The Earliest Commentator on RB: Smaragdus on Benedict's Prologue," American Benedictine Review 55, no. 2 (2004): 171-193; Kardong, "'If you have Clasped Hands, Rouse your Neighbor!' Smaragdus' Comments on Benedict's Chapter Concerning the Abbatial office," American Benedictine Review 58, no. 3 (2007): 239-248; Matthew Ponesse, "Smaragdus of St Mihiel and the Carolingian Monastic Reform," Revue Bénédictine 116 (2006): 267-392; Jasmijn Bovendeert, "Royal or Monastic Identity? Smaragdus' Via Regia and Diadema Monachorum Reconsidered," in Texts and Identities in the Early Middle Ages, ed. Richard Corradini, (Vienna: Verlag, 2006), 239-251.

${ }^{7}$ Scholars have also used this portrayal of Smaragdus as a reformer monk as a means to support the narrative that the Aachen reform councils initiated a universal shift in the monasteries of the Carolingian empire. In particular, see Kardong, "The Earliest Commentator on RB: Smaragdus on Benedict's Prologue," 171-193.

${ }^{8}$ H. Peltier, "Smaragde," Dictionnaire de théologie Catholique 14, part 2 (1941), col. 2247; Kardong, "The Earliest Commentator on RB: Smaragdus on Benedict's Prologue," 172-173.

${ }^{9}$ Although he asserts that Smaragdus was a missi, he does not indicate how he came to this conclusion. I cannot find any indication that Smaragdus was a missi in any of his writings or in the short description of his life and epitaph in the Chronicon Sancti Michaelis. See Holtz, Liber in partibus Donati, xiii.

${ }^{10}$ The only surviving account of Smaragdus' life is in the Chronichon Sancti Michaelis, which was written during the early twelfth century. On this text see Ponesse, Learning in the Carolingian Court and Cloister, 20-24. 
Kardong bases his claim that Smaragdus supported the reform movement on two direct references to the councils of Aachen in the Expositio. These references deal with the omission of the Alleluia during Septuagesima, and the placement of the abbot's table within the common refectory. ${ }^{11}$ Kardong, in accordance with the work of Dubreucq, also points to Smaragdus' copious use of Benedict of Aniane's Concordia Regularum-a textual link that demonstrates, he argues, a shared ideology defining the Aachen documents. ${ }^{12}$ Yet, Kardong does not mention that with the exception of four references in the first two books of the Expositio, the heavy citation of the Concordia regularum begins only in the third book. There is no mention or citation of the text whatsoever in Smaragdus' lengthy prologue. ${ }^{13}$ This lack of reference to Benedict of Aniane's text in the first two books of the Expositio indicates that Smaragdus did not find it useful in his discussion of the regulation of interiority and suggests that the two abbots present different monastic programs.

Ponesse indicates three other indirect references to the capitulary decrees in the text: that monks ought not to leave the cloister to bury the dead, that 138 psalms ought to be sung throughout the day, and that abbots must practice the same customs as their monks. ${ }^{14}$ However, as he asserts, it is not these citations which signal Smaragdus' desire to adhere to and even extend the capitulary texts of $816 / 817$, but the nature and interest

${ }^{11}$ Kardong, "The Earliest Commentator on RB: Smaragdus on Benedict's Prologue," 172-173.

${ }^{12}$ Ibid., 182; Alain Dubreucq, "Smaragde de Saint-Mihiel et son temps: Enseignment et bibliothèques à l'époque carolingienne," 22-23. For more on the historiographic connection between Benedict of Aniane and the reform movement see chapter one, pages 15-16. For the direct references to the councils in Smaragdus' Expositio see footnote 1 above.

${ }^{13}$ Dubreucq, however, does note this shift and suggests that Smaragdus must have written the first two books of the Expositio prior to the councils of Aachen in 816 and 817. See Dubreucq, 22-23.

${ }^{14}$ Ponesse, Learning in the Carolingian Court and Cloister, 156-158. 
of composing a commentary on $R B .{ }^{15}$ A text featuring $R B$ so prominently is in line with the first capitulum of the 816 decree, which states:

that abbots must read out the Rule [of Saint Benedict] as soon as they return to their monasteries discussing it word by word and, upon understanding it, must fulfill it. ${ }^{16}$

Interpreting Smaragdus' Expositio as a response to and aid in fulfilling this capitulum, Ponesse underscores that Smaragdus not only read through $R B$, but he also commented thoroughly on nearly every word of the text. ${ }^{17}$ In this regard, he asserts that Smaragdus must have agreed with the decisions of the council of Aachen enough to put them into effect.

While these arguments confirm that Smaragdus was very well aware of the Aachen decrees, and suggests that he approved of aspects of the reform, there are also many indicators that Smaragdus was not completely in favour of the capitularies. Depictions of Smaragdus as a reformer appear only in twentieth-century scholarship, as the sole medieval record of his life survives in an eleventh-century chronicle which limits itself to his role within the community at Saint Mihiel. ${ }^{18}$ The chronicler states that Smaragdus was a famous abbot, particularly renowned for his text the Diadema monachorum, who succeeded in moving the monastery from a steep mountain side to a

${ }^{15}$ Ibid., 34.

${ }^{16}$ The second and third capitula also refer directly to $R B$, declaring that monks must memorize and perform their office according to $R B$. See Acta Praeliminaria, 435: "capitulum, ut abbates mox ut ad monasteria sua remeauerint regulam per singula verba discutientes legant et intellegentes adimpleant." books.

${ }^{17}$ Smaragdus' commentary in the third book is much less extensive than that of the first two

\footnotetext{
${ }^{18}$ Ponesse argues for the accuracy of the chronicle based on his examination of five charters issued by Louis the Pious which match the declaration of rights and privileges cited in the text. See Ponesse, Learning in the Carolingian Court and Cloister, 21-22.
} 
nearby, more convenient site on the river Meuse. ${ }^{19}$ The chronicler further praises the abbot for having obtained royal protection and a number of other privileges for the monastery from Louis the Pious. ${ }^{20}$ Though these feats demonstrate that Smaragdus was an active abbot, they indicate very little of his attitude toward the monastic reforms at Aachen. They do not portray the abbot as a man heavily invested in reforming Carolingian monasticism throughout the empire, but rather as an abbot who was concerned about the wellbeing of his own community. ${ }^{21}$

The concern and focus for his community suggests that it—not universal reform-was Smaragdus' primary interest. Scholarship on the Expositio buttresses this idea. Shifting his opinion in subsequent scholarship, Ponesse notes that Smaragdus deviated from the capitulary decrees over the amount of discretion the abbot ought to hold, particularly in "exceptional circumstances."22 By heightening abbatial power in

${ }^{19}$ Chronicon Sancti Michaelis, ed. Ludovicus Tross (Hammone: 1857), 8-9: "Hic igitur ut vir consilii, vir prudentiae, vir discretionis, considerans praedicti montis habitationem humanis necessitatibus minus congruentem, propter quae scilicet ac ceterarum rerum necessariarum laboriosam ad ardua devectionem, haud procul a praedicto monte, uno videlicet miliario, iuxta ripam Mosae monasterium instituit." This site was also noticeably less secluded that the previous location, suggesting a desire for further contact with the outside world.

${ }^{20}$ These other privileges include the exemption of paying customs for the transportation of goods between the monastery and its other properties, enforcing the payment of the nines and tens (tithes), and ensuring that monks had the power to elect their own abbot as according to the second chapter of $R B$. See Chronicon sancti Michaelis, ed. Ludovicus Tross, 9: "contulit et aliud de libertate carrorum et saumariorum et patellarum in vico et marsallo et navium. Contulit et aliud, ut nonas et decimas ei persolvant, qui beneficia de eo tenent; contulit et aliud, ut liberam potestatem habeant fratres de se ipsis abbatem eligendi secundum regulam."

${ }^{21}$ I would not credit this representation of Smaragdus as an abbot dedicated to his own monastery as part of a ninth-century narrative style. The vita Benedicti Anianenesis, which I examine in the following chapter, presents Benedict as a monk who was extremely involved in the affairs of monasteries outside his own at Aniane or Inde. See chapter four, 96-100.

${ }^{22}$ Ponesse, "Smaragdus of St Mihiel and the Carolingian Monastic Reform," 387. I suggest that Ponesse revised his conclusions because in his doctoral dissertation he presents Smaragdus' attitude toward the reform capitularies as "generally favourable toward the legislation imposed at Aachen, provided that it did not disrupt the current practice of the monastery." See Ponesse, "Smaragdus of St Mihiel and the Carolingian Monastic Reform," 391; cf. Ponesse, Learning in the Carolingian Court and Cloister, 161. 
these circumstances, the Expositio differs from the capitularies which attempted to place the abbot beneath the authority of $R B$ and the capitularies, responsible only for enforcing and following its command. ${ }^{23}$ Ponesse further argues that Smaragdus imposed less strict regulations for bathing and clothing, more lax dietary restrictions for guests and pilgrims, and more allowance for traditional practices to continue in the singing of the liturgy. ${ }^{24}$

These deviances indicate that Smaragdus' response to the reform "cannot be measured in absolute terms.",25

Beyond the differences to which Ponesse points, there are further contradictions to the Aachen capitularies which merit consideration. In one of the chapters where Smaragdus directly cites the reform councils, he suppresses aspects of the capitula on the reception of guests within the monastery. One reference to the capitularies occurs in relation to the location of the abbot's table within the refectory:

But recently it was found beneficial by the council of bishops, abbots, and other Franks, that for his own safety and the safety of the brothers he ought to have his table in the common refectory when they are with guests. Indeed when they are lacking guests, let him have his meal with whoever he wishes, in the presence of the brothers. ${ }^{26}$

${ }^{23}$ Primae decreta, chapter 1 and 3, 457-458: "ut abates mox ut ad monasteria sua remeaverint regulam per singular verba discutientes pleniter legant et intellegentes domino oppitulante efficaciter cum monachis suis implore student" and "ut officium iuxta quod in regula sancti Benedicti continetur celebrant."

${ }^{24}$ Ponesse also argues that Smaragdus also imposed a less severe boundary between the monastic and secular worlds, allowing for more interaction between the two communities. As I suggested in my previous chapter, however, the capitularies construct a monastic program which is more concentrated on the regulation of the exterior body. This results in strict regulations concerning the movement of monks beyond the walls of the cloister, or the entrance of secular bodies into the monastery. I suggest, however, that this does not indicate a lack of desire for contact between the two communities, simply that it is done in particular manners. See chapter two, 30-57.

${ }^{25}$ Ponesse, "Smaragdus of St Mihiel and the Carolingian Monastic Reform," 391.

${ }^{26}$ Smaragdus, Expositio, chapter 53, col. 892D: "Sed modo ab episcoporum, abbatum, et caeterorum Francorum magno concilio salubre inventum est concilium, ut pro sua et fratrum custodia habeat in communi refectorio mensam, ubi quando adfuerint cum hospitibus, quando vero defuerint, cum quibus voluerit, reficiat coram fratribus." 
Smaragdus openly cites the reform council and uses the capitularies to add authority to his alteration of the custom set forth in $R B$. He emphasizes a sense of community in this passage by asserting that all members of the monastery eat in the same room, whether they are permanent or transient residents. Yet, Smaragdus places much more emphasis on the rituals surrounding the initial reception of guests at the entrance of the monastery than the capitulary texts. He underscores that the proper members of the community should greet the guest, pray together, exchange the kiss of peace, and even prostrate themselves before the new arrival. ${ }^{27}$ Furthermore, he also describes how a monk must show humility through the inclination of the head or prostration of the body upon the departure of guests. $^{28}$ The capitularies, on the other hand remain silent on entry rituals, highlighting instead that interaction ought to occur primarily within the refectory. ${ }^{29}$ The Expositio and the capitularies, therefore, present contrasting regulations surrounding reception: Smaragdus builds upon the entry and exit rituals of $R B$, while the capitularies concentrate on reception rituals within the refectory.

The shared language between the Aachen capitularies and Smaragdus' text indicates that the divergence between the two texts did not likely result from a lack of information on the part of Smaragdus. It is instead more likely that Smaragdus selected certain components of the decrees which supported his own monastic program. In this instance, he establishes the relationship that ought to exist between members of the monastery and secular guests as one which is welcome and communal. Smaragdus

\footnotetext{
${ }^{27}$ Smaragdus, Expositio, chapter 53, col. 890D-891C.

${ }^{28}$ Ibid., col. 891B.

${ }^{29}$ Primae decreta, chapter 25, 464: "Ut abbas vel quispiam fratrum ad portam monasterii cum hospitibus non reficiat."
} 
heightens the attention surrounding the reception of a guest at the door of the monastery through specific greeting and departure rituals. ${ }^{30}$ The capitularies, alternatively, concentrate on the refectory as the central place for receiving guests within the monastery. Thus, Smaragdus mentions the councils, but only to the extent that they support his own monastic agenda.

Beyond direct or indirect contradictions with the Aachen capitularies, however, Smaragdus presents a monastic program in his Expositio different from that which the reform councils advocated. Whereas the capitularies concentrated on regulating exterior monastic customs and practices, Smaragdus constructs a monastic program founded on regulating interior devotion. The manner in which the abbot divides his text into three books suggests this priority: The first book comments on the preface and the first three chapters of $R B$, the second on the fourth through seventh chapters, and the final book on the remaining sixty-six chapters. It is these sixty-six chapters which deal primarily with exterior regulations resembling those in the capitularies, such as the order in which psalms are to be said, ${ }^{31}$ how much food and drink monks ought to receive, ${ }^{32}$ and how monks ought to sleep. ${ }^{33}$ Yet, Smaragdus' commentary of this section is much less

\footnotetext{
${ }^{30}$ Smaragdus comments later in the chapter on the line in $R B$ which states, "One who is not so ordered is not to associate with the guests or converse with them." He clarifies that this statement means a monk "is not to join them[the guest] in conversation." This concentration on the lack of dialogue between the two parties would suggest that they continue to have a form of non-verbal association. The monk is not supposed to ignore the presence of the guest. Thus, the acting out of rituals and the presence of a guest within the refectory are important symbols of acknowledgement and acceptance within the community. Smaragdus, Expositio, chapter 53, col. 893B: "Hospitibus autem, cui non praecipitur nullatenus societur, neque colloquatur... id est, ad fabulas faciendas non eis jungatur."

${ }^{31}$ Smaragdus, Expositio, chapters 10 and 17, col. 832A-832B and 836D-837C.

${ }^{32}$ Ibid., chapters 39,40 , and 41.

${ }^{33}$ Ibid., chapter 22 .
} 
extensive than in the first two books of the work and relies much more heavily on Benedict of Aniane's Concordia Regularum. ${ }^{34}$

Kardong downplays Smaragdus' decision to concentrate on the preface and first seven chapters of $R B$, suggesting that "at certain times he seems to have realized the magnitude of his task, and his explanations of subsequent chapters became much more laconic, even perfunctory." ${ }^{, 35}$ In other words, he simply "ran out of steam."36 As I contend in the following section, however, rather than simply petering out, Smaragdus intentionally commented more on the first two sections of the text, as they did not dwell so much on the regulation of monastic customs. Instead, the first two books provided a vehicle through which Smaragdus could write about the interior spirituality of monks.

\section{INNER BODIES, INNER CLOISTERS, AND THE DEFINITION OF MONASTIC ROLE}

Much like the capitularies, Smaragdus attempts to establish a distinct role for monks within his Expositio. Whereas the capitularies define this role by the physical location of monks within the cloister, ${ }^{37}$ Smaragdus largely defines monks through their interior devotion. He begins his text by comparing the will of secular and monastic men, stating:

\footnotetext{
${ }^{34}$ Smaragdus does not comment at all on chapter 10 , choosing instead to simply copy out $R B$ verbatim. I should also note here that the lack of emphasis on the third book detracts from the argument that Smaragdus was very much in favour of Benedict's Concordia Regularum. He devotes much more attention to matters which Benedict does not address.

${ }^{35}$ Terrence Kardong, "Smaragdus and his Work," in Commentary on the Rule of Saint Benedict (Kalamazoo: Cistercian Publications, 2007): 3.

${ }^{36}$ Terrence Kardong, "The Earliest Commentator on RB: Smaragdus on Benedict's Prologue," American Benedictine Review 55, no. 2 (2004): 184.

${ }^{37}$ I demonstrate this in the previous chapter. See 30-57.
} 
We call one's own will the will one is born with, which is personal and private to each person. The noun 'will' derives from the verb 'to will.' It consists of a judgment of the mind; it is the active power a person has to make plans and take decisions. Living like this is living according to man, not according to God. For that man lives according to man who lives according to himself and his own will; who comes and goes with whom he wants and where he wants; who sleeps as much as and when he when wants... Now the man who lives according to God does not take carnal delight in any of these things... and whatever he desires or does, he does not want it to proceed for his own will but from the will of God, whom he longs with all his might to please. ${ }^{38}$

In his discussion of the will, Smaragdus explains that man has a personal will and has individual control over his desires and actions. The religious man must reject his personal will and instead try to fulfill only the will of God. The defining difference between the secular man and the monk is their decision to renounce or follow their personal desires. However, the will is not part of the exterior make-up of a man and Smaragdus does not attempt to regulate it by manipulating exterior monastic customs. Instead, he instructs monks to reject their personal desires and act out the will of God.

In subsequent discussions of the will, Smaragdus constructs a more explicit hierarchy between exterior and interior devotion. He explains that a monk who does "not separate himself from [the world] either by desire or thought or deed, but only through the tonsure and the religious habit... lies to God.",39 For Smaragdus, it is not enough that a man simply take on the exterior appearance of a monk. This condemnation of

\footnotetext{
${ }^{38}$ Smaragdus, Expositio, col. 695B: "Propria enim unicuique dicitur vernacula, privata, vel peculiaris voluntas. Voluntas autem ab eo quod est velle nomen accepit. Est enim arbitrium mentis potestas consilii sui, atque propositum sensus sui. Et hoc est secundum hominem, non secundum Deum vivere. Ille enim secundum hominem vivit, qui secundum seipsum et secundum voluntatem suam vivit, qui cum quibus vult et ubi vult pergit, quantum vult et quando vult dormit... Qui autem secundum Deum vivit, non eum carnaliter haec omnia delectant, sed quae spiritalia sunt spiritaliter eum aedificant, et omnia desideria carnis spiritalis desiderii delectatione compescit... et quidquid agit, non vult ex sua, sed ex Dei sui voluntate procedere, cui placere totis viribus concupiscit."

${ }^{39}$ Ibid., prologue, col. 727C: "se nec desiderio, nec cogitatione, nec opere ab illo separat; sed tantum per tonsuram et religionis habitum Dei sese mentitur filium."
} 
hypocrisy would also suggest that simply acting out established monastic customs would not suffice in Smaragdus' monastic program. Rather, it is essential that they think and desire as a monk would. The abbot states, "a heavy man is one who does not shamelessly practice sin in their work, but is nevertheless frequently being soiled by vices in their mind. And although he does not practice the evil deed, nevertheless he bears the shameful sins in thought." ${ }^{40}$ Just as wearing a monastic habit does not satisfy Smaragdus, in this passage, he considers a monk sinful if he merely thinks about an evil deed, without needing him to act upon this thought.

While Smaragdus places emphasis on monastic interiority, he conceives of the inner monk in a very physical sense. When commenting on the prologue, the abbot constructs a fragmented inner body. He advises monks to listen with the "ear of their heart," to open the "eyes of their heart," to gird up the "loins of the mind" by having faith and performing good deeds, and to "run with the soul" from virtue to virtue. ${ }^{41}$ By these references, Smaragdus constructs a complex picture of the inner monk which blends an array of body parts associated with the mind, heart, and soul together to form a type of incongruous body. He makes it very clear that he is referring to an inner body in the way he always distinguishes the inner body part from its exterior counterpart. He notes, for instance, “'ear' derives its name from 'hearing' and 'drinking in', For the body's ear drinks in men's words, while the heart's ear drinks in the understanding of what is

\footnotetext{
${ }^{40}$ Ibid., prologue, col. 726C: "Ponderosus vero est qui vitia turpiter non exercet in opere, ab illis tamen frequenter polluitur in mente. Et quamvis opus nefarium non exerceat in cogitatione, tamen turpia vitia gestat."

${ }^{41}$ Smaragdus refers to the ear of the heart in his Expositio on cols. 682C, 705B-705C, 707A-707C, however, Benedict first uses this phrase in his own prologue. He refers to the eyes of the ear in col. 693B, the loins of the mind in cols. 712B-712C, and the running of the soul in cols. 723D-724A. He also states that monks should speak with their hearts in cols. 709D and 715C-715D, however, this does not seem as corporeal as the other references, as he is urging monks to speak the truth. Finally, he urges souls not to harden their hearts in col. 705A.
} 
said. ${ }^{, 42}$ Smaragdus ensures that there is no confusion over the interior or exterior location of the ear, eyes, or limbs to which he refers.

Having established the importance of the inner body for monks, Smaragdus expresses the need to regulate it just as one might the exterior body. He indicates that monks have control over the interior body and that their inner actions have consequences which affect their ability to attain salvation. He writes:

The soul which proceeds along the broad and spacious way, giving no thought to the future life and glory, but with eyes closed and sleeping becomes daily worse and hastens to eternal ruin, is asleep; the soul which thinks about eternal life and future glory and makes its way along the strait and narrow way, and grows and is renewed daily in virtues... is keeping watch. ${ }^{43}$

Echoing the narrative of itinerancy in his metrical preface, Smaragdus personifies the soul and suggests that the interior monk must choose between two paths. One path is difficult and narrow but leads straight to God, while the other is easy, broad, and spacious but leads to eternal ruin. In presenting the journey to God as narrow, Smaragdus transforms the path into a form of cloister. The narrow boundaries of the path constrict the monk, as would the physical walls of a cloister. Yet, the path does not hold the monk in one static location like the monastery, but rather leads him closer to God. By constructing a monastic journey in which monks can only attain salvation by contemplative means, Smaragdus privileges a form of internal claustration.

\footnotetext{
${ }^{42}$ Smaragdus, Expositio, prologue, col. 682C: "Auris enim ab audiendo vel hauriendo vocatur. Auris enim corporis hominis voces, cordis autem auris intellectum haurit sermonis."

${ }^{43}$ Smaragdus, prologue, col. 704A: "Dormit anima, quae perlatam et spatiosam progrediens viam, de futura vita vel gloria nil cogitat, sed clausos oculos vel dormiens quotidie pejor effecta, ad aeternum interitum properat. Vigilat, quae de aeterna vita et futura cogitans gloria per arctam et angustam gradiens viam, virtutibus quotidie crescit et innovatur, et ut ad creatoris sui cognitionem perveniat laborare non cessat."
} 
He refers to this inner cloister explicitly within the Expositio, presenting

claustration as having two senses. The abbot associates the noun claustrum with a physical monastic enclosure, referring to monks being cast out of, or abandoning the enclosure, ${ }^{44}$ and noting that the enclosure ought to contain all necessary food supplies. ${ }^{45}$

These references to the claustrum suggest that it was a physical place which one could enter or leave and within which one could bring goods. Yet, in the second book of the Expositio, Smaragdus also refers to a claustrum which is less material. ${ }^{46}$ He states, "when harmful forgetfulness is driven from the enclosure of our heart, then fruitful remembrance grows and overflows in us. ${ }^{, 47}$ The enclosure to which Smaragdus referred is located within a monk's heart. ${ }^{48}$

${ }^{44}$ Ibid., chapter 58, 924B-925D.

${ }^{45}$ Ibid., chapter 35, 866B-868C.

${ }^{46}$ The references to the cloister as an exterior, physical place in the third book of the Expositio, and the references to the cloister as interior in the second book, reflects the broader interior focus of the text which I referred to earlier. Again, I emphasize that Smaragdus chose to comment more extensively in his first two books because they lent themselves better to a discussion of interiority than the third book, which concentrates heavily on the regulation of monastic practices.

${ }^{47}$ Smaragdus, chapter 7, col. 809B: "Cum enim a claustro cordis oblivio fugatur damnosa, tunc in nobis fructifera crescit." Smaragdus also makes another reference to an interior cloister in chapter 6, 802D803A: "Quae propter taciturnitatis gravitatem tenendam raro conceditur discipulis praedicanda, ne forte, dum taciturnitatis suae incautus egreditur claustra, in elationis praeceps foveam cadat, aut silentii sui transeat terminum, et suae patiatur animae detrimentum, perdat taciturnitatis proficuam gravitatem, et in damnosam incidat animi levitatem." In this passage, the cloister contains a monks' speech and it protects their minds. Comparing this with his reference to the enclosure of the heart, it is evident that Smaragdus blends the location of the interior cloister between the heart, mind, and soul in the same way he did when discussing the interior body. I would argue that he blends these references because he conceives of the interior body as occupying all of the spaces.

${ }^{48}$ Though Smaragdus presents an interior cloister, he makes it explicit that monks continue to benefit from a community. He writes, "there are many dangers very near for the solitary. In the first place he pleases himself in all his deeds and has no one else to test his work; then he does not know what vices about in him and what virtues he lacks; he has no one with whom he may test his humility, he does not pay obedience to a brother, he does not show patience in injuries. Therefore, it is better for a monk to live in a monastery." It is clear from this statement that the abbot was not suggesting that monks do not need to be physically cloistered, but rather that they are much better off with both interior and exterior claustration. See Smaragdus, Expositio, chapter 1, cols. 728B-728C: "Multa enim pericula sunt solitario proxima. Primum quia sibimetipsi in omnibus actibus suis placet, et nullum alium habet qui opus ejus probet. Deinde quaeque illi vitia abundent, quaeque virtutes desint, non cognoscit. In quo humilitatem suam probet 
Corresponding with this duel definition of claustration, Smaragdus imposes a doubled definition of stabilitas among those who dwell within the interior and exterior cloister. Monks occupying this enclosure ought to:

have firmness of mind and stability in community, so as not to begin wandering through various territories or migrating from one monastery to another...It were better for him to abandon his mind's tendency to wander, and hold firmly to stability of heart and of place. ${ }^{49}$

Whereas the concept of stabilitas in $R B$ refers more firmly to a stationary presence within the cloister, ${ }^{50}$ Smaragdus asserts both interior and exterior forms of stability. In one sense, Smaragdus discusses an exterior or physical idea of stability of place (stabilitas loci), while also suggesting an interior idea of stability of heart (stabilitas cordis). ${ }^{51}$

In his text, Smaragdus places more emphasis on the concept of stability of heart than of place. Addressing the issue of pilgrim monks who left the confines of their monasteries and requested lodging in another monastery, he states, "although he does not promise since he has already promised, he should fix his stability both in his heart and by word... so that he may not deserve to be condemned for his much and unlawful

neminem habet, obedientiam fratri non impendit, in jejuniis patientiam non ostendit. Melius est ergo monacho ut vivat in monasterio."

${ }^{49}$ Smaragdus, Expositio, chapter 4, col. 794B: "In quibus qui vult habitare, firmitatem in mente et stabilitatem debet habere in congregatione, ne vagari incipiat per diversa terrarum spatia, aut transmigrare de cella ad alteram, et de propriis ad non propria loca."

${ }^{50}$ In $R B$, the first mention of stabilitas appears in the very first chapter, where the author denounces gyrovagui. Described as guests who "spend their entire lives drifting from region to region," they are framed as being particularly evil due to the fact that they are "always wandering and never stable." In other words, gyrovagui are disparaged because they wander the outside world and refuse to remain stable in one monastery. See $R B, 170-171$ : "Quartum vero genus est monachorum quod nominator gyrovagum, qui tota vita sua per diversas provincias ternis aut quaternis diebus per diversorum cellas hospitantur, simper vagi et numquam stabiles."

${ }^{51}$ As far as I have been able to ascertain, Smaradgus' conception of stabilitas cordis is unique within ninth century sources. 
wandering." $\$ 2$ This second vow of stability of heart calls into question the importance of a monk's stability of place. Smaragdus does not reprimand the travelling monk. Instead, he provides instruction on how to avoid accusations of unlawful wandering. Thus, Smaragdus suggests that a monk does not break his vow of stabilitas by simply changing locations. Rather, he transforms stabilitas into an interior conception in which a monk remains stable as long as his heart is fixed on God.

Smaragdus' discussion of the interior will, body, claustration, and stability demonstrates that he is extremely concerned with presenting a monastic program regulating a monk's practice of contemplation. Although he does not ignore the external bodies of monks or suggest that the regulation of the exterior is unimportant, it is clear that Smaragdus is most interested in addressing interior spirituality. Therefore, although Smaragdus advocates for the use of $R B$ much like the Aachen capitularies, a closer examination of the text reveals that they are markedly different in the manner in which they conceive of the monastic role. Smaragdus defines a monk primarily by his interior devotion and contemplation, whereas the capitularies concentrate on regulating exterior monastic practices.

\section{INTERIOR JOURNEYS BY GOOD WORKS: ACTIVE HOSPITALITY AND ITINERANCY}

Throughout the Expositio, Smaragdus asserts the need for monks to perform good works. ${ }^{53}$ He writes:

\footnotetext{
${ }^{52}$ Ibid., col. 909D: "ita et iste quamvis non promittat, quia jam promissum habet, firmet tamen stabilitatem suam corde simul et verbo coram... ne mereatur ipse damnationem pro multa sua et illicita vagatione."

${ }^{53}$ The connection between good works and advancement along the path to God appears at the beginning of book two, when Smaragdus addresses the chapter, "The Instruments of Good Works." He writes, "It is these virtues which blessed Benedict wanted to set down in an orderly way in this chapter; by
} 
there is another kind of person - and especially of monk - who turns away from evil and yet performs no good at all. He has left behind earthly toil in the world, and in the monastery follows ideal pursuits. Of such people... the apocalypse [says]: Because you are neither cold nor hot but lukewarm and cause nausea, I will begin to vomit you out of my mouth. ${ }^{54}$

By equating physical presence without a corresponding intentionality in the cloister with a lukewarm devotion to God, Smaragdus ties the practice of good works into his discussion of will. The monk who does not perform good acts is following his own ideal pursuits and, therefore, not fulfilling the will of God. Although the monk occupies the sacred place of the monastery, his lack of interior action renders him even more despised than were he to not be a monk at all. In a similar manner, Smaragdus alludes to a passage in the Book of Matthew which states that a wise man builds his house upon rock and expands upon it, stating:

He lays as the foundation of his house the initial stage that consists of first conversion; as the middle section of his wall he adds the middle stage that consists of doing good; the finishing touch of his perseverance is the perseverance which issues in perfection. ${ }^{55}$

Smaragdus intends his metaphor of building a proper house to apply to the development of a proper monk. In underscoring the necessity of good acts, the abbot suggests that perfect interior spiritual development follows proper exterior actions.

their means the order of good monks is formed in purity of life, so that with these as an adornment a monk may advance... and unite himself to the society of all the saints and angels." See Smaragdus, Expositio, chapter 4, cols. 749A-749B.

${ }^{54}$ Ibid, Expositio, prologue, cols. 710A-710B: "Aliud vero genus hominum et valde monachorum est, quod divertit a malo et operatur minime bonum. Terrenos in saeculo relinquit labores, et in monasterio sectatur otiositates.... Et in Apocalypsi: Quia nec frigidus, nec calidus, sed tepidus es, et nauseam facis, incipiam te evomere de ore meo."

${ }^{55}$ Ibid., prologue, col. 718A: "id est initium primae conversionis quasi fundamentum domus suae, et medietatem bonae actionis quasi medium parietis suae, et perseverantiam perfectionis quasi consummationem perseverantiae suae super fundamentum illud ponit." Biblical citation from Mt 7:24. 
An important good act which Smaragdus asserts a monk ought to perform is the proper reception of guests and the active pursuit of hospitality. Smaragdus emphasizes that one does not simply receive guests, nor should monks think of guests as burdensome. Instead, he states:

hospitality must be pursued; this shows not only that we are to receive a guest who comes to us, but we are also to look for, be anxious about, follow up and search diligently everywhere for guests, lest perchance they be sitting in the streets or lying down without a roof over them... for this [reception], one obtains the final reward, when the Lord will say... 'I was a stranger and you took me in. ${ }^{, 56}$

The idea that one does not only receive, but actively seeks out guests, presents a very positive interpretation of the relationship between the monastery and the outside world. The active pursuit of guests does not express a forced relationship, but desired contact. Within this framework, interaction with guests is not associated with a desire to be involved with secular affairs, but rather the abbot portrays it as a virtuous act performed for God.

Smaragdus, however, does not simply advocate for the reception of guests because that action, in itself, is a good deed. He expresses that monks are to show suitable honour to all guests in order that "having been received fittingly by us they may without murmuring return to their own affairs as our friends." ${ }^{57}$ Not only, then, does Smaragdus want to actively receive guests, he embraces their reception as an opportunity

${ }^{56}$ Ibid., chapter 53, cols. 890A-890B: "Dicens enim sectandam esse hospitalitatem, non illud solum ostendit, ut venientem ad nos hospitem suscipiamus, sed et requiramus et solliciti simus, et sectemur, ac perquiramus ubique hospites, ne ubi forte in plateis sedeant, ne extra tectum jaceant."

${ }^{57}$ Smaragdus, Expositio, chapter 53, cols. 890C-890D: "ut congrue a nobis recepti sine murmurio ad propria revertantur amici." 
to befriend visitors, referring to them as amici. ${ }^{58}$ He further urges monks to show guests compassion and "the full and perfect service of love," so that the community may receive them "in the midst of [their] heart." 59 For Smaragdus, therefore, the reception of guests was certainly not a passive affair. Far from begrudging the intrusion of the outside world within the walls of the monastery, the abbot received guests with love and actively sought to form friendships with his visitors.

Smaragdus particularly voiced his desire to actively pursue the reception of pilgrims and other ecclesiastic guests. He writes that a good pilgrim "should even be persuaded to stay... must be received, held on to and attracted."60 Again, this interpretation expresses a desire to seek pilgrims out rather than simply accepting them when they arrive. In fact, Smaragdus outlines the ways in which a community might attempt to convince a pilgrim to remain with them once they arrive. Addressing the pilgrim himself, Smaragdus implores:

Brother, stay with us in this monastery and do not move on, so that others may be instructed by your good example. For there is no need to seek God in some other

${ }^{58}$ In the following sentences, Smaragdus indicates that he considers both secular guests (hospites) and pilgrims (peregrines) to be friends. He writes: "And fitting honor should be shown to all... Especially to those of the household of faith and to pilgrims. A member of the household means a familiar friend and comrade; these we understand in two ways: either as all Christians in general, who have with us one faith and one baptism, or monks especially, who offer to God a special worship of faith and religious service." See Smaragdus, Expositio, chapter 53, 890C-891A: "Et omnibus congruus honor exhibeatur... Maxime domesticis fidei et peregrinis. Domesticus dicitur amicus familiaris, vel sodalis; quos duobus modis intelligere debemus, sive omnes generaliter Christianos unam nobiscum fidem, unum habentes baptisma; sive specialiter monachos, qui nobis cum Deo peculiarem Dei cultum, et religionis exhibent famulatum."

${ }^{59}$ First citation from Smaragdus, Expositio, chapter 53, col. 891C: "et obsequium plenum, et perfectum amoris"; second citation from ibid., chapter 53, 892A: "in medio cordis nostri."

${ }^{60}$ Ibid., chapter 61 , cols. 910A-910B: "verum etiam suadeatur... boni vero suscipiendi, tenendi sunt atque adtrahendi." 
place; he is everywhere, at all times and totally...by toiling well here and serving the Lord you will be able to gain the kingdom of heaven. ${ }^{61}$

This abrupt change of addressee in the text emphasizes the extent to which Smaragdus wished to welcome brothers within the community and saw pilgrims as potential recruits. He does not reprimand the pilgrim for having moved in the world outside the cloister, but instead notes that the pilgrim may "fix his stability of heart" within the new community so as not "to be condemned for his much and unlawful wandering." 62 In this passage, Smaragdus makes it clear that not all travel outside the monastery is unlawful, as stability of heart and interior claustration continue to guide the pilgrim.

Just as Smaragdus accepts travelling monks into his community, he also is willing to send monks outside the cloister. In a chapter on brothers who work away from the monastery, the abbot cites Pachomius, who states, "should they be on a ship, in the monastery, in the fields, on a journey, in any kind of services, they shall not let pass the times for praying and singing the psalms. ${ }^{.63}$ By citing this excerpt, Smaragdus emphasizes that the opus Dei may be done in all places, not simply the monastery. Danger befalls the itinerant monk who neglects to fulfill $R B$ and the "requirements of devotion" while outside cloister walls. ${ }^{64}$ Within this interpretation, monks need not

\footnotetext{
${ }^{61}$ Ibid., chapter 61, cols. 910B-910C: "Sta, frater, nobiscum immobilis in hoc monasterio, ut bono tuo alii erudiantur exemplo. Non enim opus est in aliquo quaerere loco, qui ubique est semper notus.... quia hic bene laborando Dominoque serviendo coelorum poteris conquirere regnum."

${ }^{62}$ Ibid., chapter 61, 909C-909D: "firmet stabilitatem suam, sive in corde tantum, sive in corde simul et verbo... ne mereatur ipse damnationem pro multa sua et illicita vagatione."

${ }^{63}$ This passage also appears in the Concordia Regularum (57.2). See Smaragdus, Expositio, chapter 50, col. 889A.

${ }^{64}$ Smaragdus is citing an excerpt from the Rule of Basil, which appears in the Concordia Regularum (57.3). See Smaragdus, Expositio, chapter 50, col. 889A.
} 
remain inside the physical cloister, although Smaragdus does indicate that it serves as an aid to monks who otherwise might neglect certain duties. ${ }^{65}$

Beyond the reception of secular and ecclesiastic guests and the travel of monks outside the cloister, there is another chapter in $R B$ which mentions the reception of letters or other things. ${ }^{66}$ Citing the Concordia Regularum, Smaragdus harshly denounces that monks are to receive anything from the outside world. He writes, "anyone who presumes to receive anyone's letters and gifts, if he does not at once make public what he received and from whom, shall undergo a very severe punishment." ${ }^{\text {,67 }}$ Though upon first glance this comment suggests a different attitude contradicting the one on the reception of guests, Smaragdus also notes that the reception of a gift is fine if it is "brought back into the common property and given to one who needs it." ${ }^{, 68}$ In other words, it is not the gift itself and its association with the outside world which is problematic, but rather that a monk might seem to keep something apart from the community. As long as the monastery receives the gift corporately, it is not problematic.

In the third book of his Expositio, Smaragdus addresses different forms of interaction between monks and other ecclesiastics and secular figures. However, in no way does he suggest that monks ought to avoid contact with the outside world. By linking exterior actions with interior devotion, Smaragdus is able to receive guests

\footnotetext{
${ }^{65}$ See footnote 50 above.
}

${ }^{66}$ Though in English both the reception of guests and the reception of other things use the same verb, in the original Latin Smaragdus and $R B$ use the verb suscipere to indicate the reception of a guest and the verb accipere in the reception of objects.

\footnotetext{
${ }^{67}$ Smaragdus, Expositio, chapter 54, col. 893D: "Qui vero litteras vel munuscumque accipere praesumpserit, si non statim a quo accepit et quae accepit publicaverit, districtioni severissimae subiacebit."

${ }^{68}$ Ibid.: "in rem commune redactum cui necessarium fuerit tribuatur."
} 
warmly with the knowledge that hospitality is a good act which will help monks on their journey to salvation. Guests are actively befriended and encouraged to remain within the community, monks are able to leave the monastery, and communal gifts are welcome.

\section{CONCLUSION}

The language of itinerancy, of travelling to God, permeates Smaragdus' text. He speaks of the "pellucid pathway" which monks "climb to the realms of the starry firmament," and in the very last paragraph of his text, he encourages monks to "hasten to scale the sublime heights of the virtues." ${ }^{\circ 9}$ At the beginning of his first chapter he underscores that $R B$ "leads people in the right way and never draws them in some other direction" and at the end of the second book he discusses the virtuous "steps of humility" which monks "climb... and thus they will see the God of gods in Zion.,"70

All of these passages make reference to a journey upon which monks must embark, navigating through their own sin and fault to heaven by means of virtuous acts. The Expositio in Regulam sancti Benedicti serves as a guide on this journey, making monks conscious of and attentive to their interior bodies. By constructing a monk's vocation as an inner journey, Smaragdus not only reframes itinerancy as a positive activity but also redefines the distinct monastic role within the ninth century as one which centers on interior devotion and contemplation. This approach differs from the monastic program which the capitularies present, as the Aachen reform movement advocated for the regulation of monks' exterior bodies. It was, therefore, essential in this framework

\footnotetext{
${ }^{69}$ Smaragdus, Expositio, prologue, cols. 689B and 932B.

${ }^{70}$ Ibid., col. 829B.
} 
that monks remain within their cloisters. In Smaragdus' interpretation, the interior journey renders exterior movement and contact with the outside world desired, as it aided and furthered monks along the pathway to heaven. 


\section{CHAPTER FOUR}

\section{ITINERANCY IN POST-816 HAGIOGRAPHY}

On one occasion the eminent Abbot Benedict went to that monastery to visit the brothers... The brothers were embarrassed, however, because they were very poor. But where charity is, even a little is enough, so he who presided over the brothers ordered one of them to fetch wine... The master of that cell was downcast when he heard there was little wine in the vessel, but he said confidently, "Go and bring it to us. Those who are going ahead to meet him should drink out of respect for the father. It will not fail them." The brother went and as he turned the spigot wine came out!... Those who were present glorified God and declared that it was accomplished by the merits of Lord Benedict. They drank, therefore, at will and took some with them for the sake of benediction. Lord Benedict arrived with his monks and accepted what was needful and took some of it with him on his journey. ${ }^{1}$

This visit of Benedict of Aniane to a monastery in the region of Auvergne which

Ardo describes is one of many travel narratives present in early ninth-century

hagiography. The tale emphasizes the miraculous abundance of wine which flowed from

a near-empty vessel upon the need of the house to show hospitality to a visiting dignitary.

Ardo is careful to note that the awaiting brothers only needed wine once they discovered

that Benedict intended to rest at their monastery. The text also highlights that Benedict

took only what was necessary and that once the need to provide for guests had passed, the

flow of wine stopped. Ardo likely crafts this story to underscore the restraint of the

community, but it also portrays Benedict's ceaseless itinerancy and the cultural

imperative to receive guests in Carolingian monasteries.

\footnotetext{
${ }^{1}$ Ardo of Aniane, Vita Benedicti Anianensis, PL 103, ed. J.P. Migne (1881), cols. 374D-375A:

"Ad quod monasterium dum quadam vice egregius abbas visendi gratia fratres adiret...Fratres autem qui ad providendam cellam remanserant, videntes abbatem una cum suis gavisi sunt. Et quia erat eis ingens paupertas, tristabantur. Sed quoniam ubi charitas est, etiam exigua sufficiunt, jubet qui praeerat fratribus, juveni vinum afferre... Audito autem magister cellae illius non esse vinum in vasculo, doluit, et confidens ait: Perge et affer nobis, quoniam pro amore Patris nostri bibent hi qui ad eum properant, et non deficiet eis. Perrexit frater, et abstracto duce egreditur vinum...glorificant Deum qui aderant, et meritis domni Benedicti fieri profitentur. Biberunt ergo pro velle, et secum benedictionis causa tulerunt. Domnus quoque Benedictus cum suis adveniens, juxta quod opus fuit accepit, secumque ex eo in via tulit."
} 
Both the capitulary and commentary genres explored in the previous chapters note the importance of the reception of guests. Entry and exit, therefore, is welcomed as a basic part of coenobitic life in these texts even though they rarely touch on what monks might do after leaving but before arriving. Consequently, these sources would seem to suggest that guests suddenly appear on the doorstep of monasteries, providing host monks with the opportunity to demonstrate their abundant hospitality.

Hagiographic sources written after the Aachen reform capitularies, however, present narratives such as the one above which open a window onto the journeys of monks, rather than just the reception of strangers. The description of the welcoming rituals in Ardo's narrative, for example, transforms the act of reception into a celebration of itinerancy. Ardo does not linger on Benedict's stay, but rather underscores his approach, greeting, and departure. The depiction of the monks moving from the cloister into the surrounding world suggests that entry rituals served the purpose of honouring the visiting abbot, rather than to demarcate his crossing into cloistered and sacred space. These divergences from the capitulary sources surrounding the presentation of claustration indicate that monastic ideals and values continued to vary after the councils of Aachen.

In the present chapter, I examine the three extant monastic vitae from the decade directly following the Aachen reforms of 816 and argue that they demonstrate a multivalent concept of itinerancy. These vitae include Eigil's vita Sturmi from the monastery of Fulda, ${ }^{2}$ Ardo's vita Benedicti Anianensis from the monastery of Aniane, ${ }^{3}$ and Radbertus' vita Adalhardi from the monastery of Corbie. ${ }^{4}$

\footnotetext{
${ }^{2}$ Eigil, Vita Sturmi, MGH SS 2, ed. G.H. Pertz, 365-377. All translations of the vita Sturmi are adapted from Thomas Noble and Thomas Head, eds., "The Life of Sturm," in Soldiers of Christ: Saints
} 


\section{VARIANCES IN THE SCHOLARSHIP OF POST-816 VITAE}

In a recent publication, Thomas Head suggests that scholars of early ninth-century hagiography identify a generic break with previous Merovingian writing. ${ }^{5}$ Whereas hagiography from earlier centuries might provide sacral power and authority to rival noble families, he argues that the capitulary decrees of 816 from Aachen attempted to unify ecclesiastic practice and used the vita of officially recognized saints to bolster imperial authority. ${ }^{6}$ This argument builds on Felice Lifshitz's analysis of the impact of the reform capitularies on the use of the martyrology. She points to a capitulum from the Secundae decreta which states that the martyrology ought to be recited daily at chapter assemblies and concludes that this served the reformers' interest in unity and uniformity, as "relics could not be so infinitely multiplied—or divided —-that every location could

and Saint's Lives from Late Antiquity and the Early Middle Ages (University Park: Pennsylvania State University Press, 1995).

${ }^{3}$ Ardo of Aniane, Vita Benedicti Anianensis, cols. 351B-384D. Ardo most likely wrote the text between the years 824 and 826 . Allen Cabaniss posits that 824 is the earliest possible dating of the text based on the time he believe it would have taken the monks of Inde to send Ardo notes of Benedict's life. The later dating of 826 is due to the fact that Ermoldus Nigellus' 827 poem of Louis the Pious' life makes no mention of the vita. See Allen Cabaniss, "Translator's Introduction," in Benedict of Aniane. The Emperor's Monk (Kalamazoo: Cistercian Publications, 2008), 42-43.

${ }^{4}$ Paschius Radbertus, Vita Adalhardi, PL 120, ed. J.P. Migne, cols. 1553A-1556C. The traditional dating of the vita Adalhardi is shortly after the abbot's death in 826. See Allen Cabaniss, "Introduction," Charlemagne's Cousins (Syracuse: Syracuse University Press, 1967), 2. All translations of the vita Adalhardi are adapted from Allen Cabaniss, trans., Charlemagne's Cousins.

${ }^{5}$ Thomas Head, "The Early Medieval Trasformation of Piety," in The Long Morning of Medieval Europe. New Directions in Early Medieval Studies, ed. Jennifer R. Davis and Michael McCormick (Burlington: Ashgate, 2008), 156-7, and 160. Head notes that the scholars who study the shift which occurs in hagiographic writing during the Carolingian period are Paul Fouracre, "The Origins of the Carolingian Attempt to Regulate the Cult of the Saints," The Cult of Saints in Late Antiquity and the Early Middle Ages, ed. James Howard-Johnston and Paul Hayward (Oxford: Oxford University Press, 1999), 143-165; and Julia M.H. Smith, "The Problem of Female Sanctity in Carolingian Europe c. 780-920," Past and Present 146 (1995): 3-37.

${ }^{6}$ Ibid., 157. 
possess the same set of saintly benefactors."7 Texts, on the other hand, were much easier to replicate and useful in constructing ecclesiastic uniformity throughout the empire. Shifting from the worship of diverse and localized icons and relics to a universal martyrology, therefore, Lifshitz highlights the importance of text-based piety in the Carolingian reform program of the early ninth-century.

Head's and Lifshitz's emphasis of the universalizing impact of the Aachen reforms on early ninth-century hagiographic material has been widely accepted, and thus the vitae written in the decade immediately following the councils have attracted little scholarly interest, as historians assume they follow this model. But the little scholarship which addresses these texts seems to suggest a lack of cohesion between the vitae. Not only does each vita emerge from its distinct context, they also demonstrate very different literary forms, purposes, and presentations of their subjects. When the topic of claustration or itinerancy is brought up, moreover, each vita presents a specific and different discourse.

The majority of scholarship considering the vita Sturmi focuses on the role of Boniface within the text and its connection to the vitae of other Bonifatian disciples. James Palmer describes the vita as part of a cult of saints specifically devoted to commemorate the prominent heirs of Boniface, such as Willibald and Wynnebald in Bavaria, Leoba in Hesse, and Gregory in Utrecht. ${ }^{8}$ Ian Wood develops this connection to Boniface further, claiming that the vita is really a "double life of both Boniface and

\footnotetext{
${ }^{7}$ Felice Lifshitz, "Legislation," in The Name of the Saint. The Martyrology of Jerome and Access to the Sacred in Francia, 627-827 (Notre Dame: University of Notre Dame, 2006), 121. The capitulum to which Lifshitz refers is chapter 36 of Secundae decreta. See Secundae decreta, 480.

${ }^{8}$ James Palmer, “The 'vigorous rule' of Bishop Lull: between Bonifatian mission and Carolingian Church Control," Early Medieval Europe, 13:3 (2005): 250.
} 
Sturmi,"9 and suggesting that it forms part of a corpus of missionary hagiographic texts. ${ }^{10}$

As Boniface's role within the text is not one of missionary saint, but rather inspirational

founder of the monastery of Fulda, Wood uses the itinerant narratives associated with

Sturmi to justify his interpretation of the vita as a missionary text.

In a more recent study, however, Janneke Raaijmakers argues that this

interpretation of the vita Sturmi is problematic, as Eigil composed the text long after

other Bonifatian missionary vitae. ${ }^{11}$ Instead, she asserts that the text was a monastic

foundation history which Eigil wrote upon his assuming the abbacy of Fulda in 818 . She

explains that prior to Eigil's election as abbot, the monks and previous abbot of the

monastery feuded over monastic life and their own priorities and responsibilities. In

writing the vita, she argues, Eigil attempted to end the conflict by providing a "collective

set of symbols rooted in old traditions that the monks were very familiar with, and which

must have appealed to all."12 Thus, rather than suggesting that the presence of Boniface

in the text served to link Sturmi to a missionary corpus of hagiography, Raaijmakers

\footnotetext{
"Ian Wood, "The Missionary Life" in Cult of Saints in Late Antiquity and the Middle Ages, ed. James Howard-Johnston and Paul Hayward (Oxford: Oxford University Press, 1999), 170.

${ }^{10}$ Ian Wood, "Missionary Hagiography in the Eighth and Ninth Centuries," in Ethnogenese und Überlieferung, ed. Karl Brunner and Brigitte Merta (Munich: R. Oldenbourg, 1994), 189.

${ }^{11}$ This post-816 dating of the Vita Sturmi is quite recent and originates in the work of Janneke Raaijmakers. She notes that the previous dating of the vita in the late eighth century rests on the translation and interpretation of the passage, "Charlemagne's incolumitas." Either referring to the safety of the body during life, or the preservation of his soul in the afterlife, Raaijmakers argues that the use of this word does not provide concrete evidence that Eigil wrote the vita during Charlemagne's life as previous scholars suggested (See Engelbert, Die Vita Sturmi, 16-20; and Heßler, "Zur Abfassungszeit von Eigils Vita Sturmi," 1-17). Instead, she suggests instead that the use of the phrase "to this day" (usque hodie) indicates that Charlemagne was already deceased. Furthermore, she consults the vita Aegil which mentions that Eigil wrote the vita Sturmi very recently (nuperrime). Thus, Raaijmakers concludes that Eigil must have written the vita Sturmi a bit before 820, but after the death of Charlemagne in 814 . See Janneke Raaijmakers, "Sacred Time, Sacred Space. History and Identity at the Monastery of Fulda (744-856)" (Ph.D. diss., University of Amsterdam: 2003) 68-70.

${ }^{12}$ Raaijmakers, 87.
} 
underscores that Eigil used both Boniface and Sturmi in order to construct a bond of familiarity between the monks. Within this interpretation, itinerancy in the text serves to sever Fulda from the rest of the Carolingian empire by at once suggesting physical distance from others and unity together in the vastissima deserti loca. ${ }^{13}$

Contrary to the scholarship on the vita Sturmi, scholars most often discuss the vita Benedicti Anianensis not in terms of being a work of hagiography, but rather as a source which provides historical details on the monastic reform movement and councils of Aachen. ${ }^{14}$ Annette Grabowsky and Clemens Radl have noted that this historiographic approach to the vita results from it being the only source which survives that offers any indication of Benedict's role within the reforms. ${ }^{15}$ Instead of seeing this silence as evidence of his minor role, scholars instead viewed it as the precious surviving evidence.

Distracted by the assumption that Benedict was the instigator of the Aachen reforms, scholars have not largely addressed the vita in the context of early ninth-century hagiography. ${ }^{16}$

${ }^{13}$ Raaijmakers, 73 .

${ }^{14}$ See Thomas Noble, "Louis the Pious and His Piety Re-reconsidered," Revue belge 58 (1980): 297-316; Mayke de Jong, "Carolingian Monasticism: The Power of Prayer," in vol. 2 of New Cambridge Medieval History, c. 700-900, ed. Rosamond McKitterick (Cambridge: Cambridge University Press, 1995), 622-653. Josef Semmler cites the vita in order to articulate that Louis the Pious and Benedict of Aniane share an intimate relationship, but also chastises the text as being historically inaccurate for overrepresenting Benedict's role as head abbot throughout the empire. By calling into question the historical accuracy of the text, Semmler distances himself from considering the vita as a narrative which Ardo constructed, and suggests instead that Ardo simply made a mistake in his account. See Semmler, "Introductio," Legislatio Aquisgranensis, CCM 1, 425-433.

${ }^{15}$ Annette Grabowsky and Clemens Radl, "The Second Benedict," in Benedict of Aniane: The Emperor's Monk (Kalamazoo: Cistercian Publications, 2008), 14. Grabowsky and Radl go on to note that there is a recent trend in German scholarship to "question the legitimacy of the term 'anianian reform," as Ardo's vita is the only source which asserts that the abbot held this role. See ibid., 15.

${ }^{16}$ There are a number of scholars who have engaged in a debate surrounding the contents of the vita Benedicti. The main controversy centres on col. 365D-373B, which appear in the only surviving copy of the text from cartulary of Aniane dated to the first half of the twelfth century, but do not appear in the first publication of the text by Hugo Ménard in 1638. Grabowsky and Radl suggest that either Ménard had 
The third vita, Radbertus' vita Adalhardi, has been long considered an unconventional hagiographic text. Brigitte Kasten and Josef Semmler both attribute this irregularity to Adalhard himself, who was a cousin of Charlemagne that they claim rejected the ideals of the monastic reform. ${ }^{17}$ David Ganz, however, concluded that the vita was an abnormal text based on its absence of miracle stories, the lack of detail about the saint's life, and divergences from other contemporary vitae. ${ }^{18}$ Alan Zola likewise distinguishes the vita Adalhardi on the basis of its lack of concern for $R B$ and thus indifference to the Aachen monastic reform movement. ${ }^{19}$

The fact that the scholarship engaging with these three post-816 vitae supports little uniformity presents a prima facie case for the failure of the Aachen reformers to impose any form of homogeneity onto hagiographic works in the post-816 time period. When considering the more specific subject of itinerancy, however, these texts clearly demonstrate neither a cohesive ideology, nor an adherence to the models presented in the

access to an original manuscript which is now lost, or else he printed an abridged version from the capitulary text without mentioning that he was shortening the vita. Pierre Bonnerue argues that the chapters in question from the cartulary version of the vita were most likely added in by twelfth-century monks of Aniane, who wanted to use the text in order to buttress support for their control over the neighbouring monastery of Gellone. While I cannot address all aspects of this debate within the scope of this thesis, I have chosen to use the twelfth-century version of the text due to certain textual considerations associated with that text. Most significant is the use of the word cirillionem on col. $372 \mathrm{C}$ to describe a 'wandering monk.' This word is relatively rare and I have been unable to find any instance where it is used outside of ninth-century texts. More popular is the term gyrovagus which appears in both the Regula magistri and $R B$ and is subsequently employed by other twelfth-century writers.

${ }^{17}$ Josef Semmler, "Karl der Große und das fränkische Mönchtum," in Karl der Große: Lebenswerk und Nachleben, ed. Wolfgang Braunfels (Düsseldorf: Schwann, 1965), 266; Brigitte Kasten, Adalhard von Corbie: Die Biographie eines karolingischen Politikers und Klostervorstehers (Düsseldorf: Droste, 1986), 91.

${ }^{18}$ David Ganz, "The Lives of Adalhard and Wala: Quotations in Corbie Biography," in Corbie in the Carolingian Renaissance (Sigmaringen: Jan Thorbecke Verlag, 1990), 103.

${ }^{19}$ Alan Zola, "Radbertus' Monastic Voice: Ideas About Monasticism at Ninth-Century Corbie," Ph.D. diss., Loyola University, 2008), 143-144 and 149-150. Zola is the only other scholar that I am aware of who has considered these three vitae together. He, however, assumes that the vita Benedicti Anianensis and vita Sturmi both represents the ideals of the Aachen reforms and, therefore, contrasts the text with the vita Adalhardi in order to highlight the text as different. 
Aachen capitularies of 816 and 817 . Not only do the vitae encourage monastic itinerancy above the reception of guests, but they also present distinct discourses of journeying from one another.

\section{DIFFERENCES IN THE CONCEPTUALIZATION OF ITINERACY}

The three authors of the vitae depict interaction with the world outside the cloister through narratives of itinerancy. Traveling across the Carolingian empire, monks come into contact with other monks as well as laymen and aristocrats in both sacred and secular settings. Although all three texts make extensive use of itinerant narratives, the authors employ distinct terminology in order to describe monks journeying outside the cloister, revealing different conceptualizations of movement and travel as well as numerous different benefits of and reasons for travelling.

Eigil's use of terminology in the vita Sturmi demonstrates that he conceives of three distinct forms of monastic itinerancy—-licit travel, illicit travel, and spiritual movement to God after death. When describing lawful travel, Eigil uses verbs which all invoke a sense of moving forward as opposed to just moving. Pergere is used most frequently with connotations that Sturmi moves onward, continually proceeding. ${ }^{20} \mathrm{He}$ also employs the verbs procedere, to advance, progredi, to go forward, or proficisci, to set out. $^{21}$ Thus, in Eigil's conceptualization of lawful journeying, he consistently implies that monks must always progress toward an end. He imbues a similar sense of moving forward through his use of the compound verb pervenire, to come to, in order to describe

\footnotetext{
${ }^{20}$ The verb pergo appears eleven times throughout the text. See Vita Sturmi, 171-175, and 177.

${ }^{21}$ Procedo, and progredior appear once in the text, both on page 172. Proficiscor also appears once on page 177.
} 
the arrival of the traveler at his destination. ${ }^{22}$ By this diction, Eigil implies that monastic travelers always have a purpose to their journeys.

He contrasts this kind of movement with the adverse: vagari, to wander. ${ }^{23}$ Eigil only describes one situation in which a monk moves illicitly, but it stands out as different from the other verbs which he uses to describe lawful travel in the text. Vagari conveys a sense of aimless movement, rather than movement with a specific destination in mind. Beyond sanctioned or unsanctioned physical movement, however, Eigil also distinguishes between physical forms of travel and spiritual movement to God after death by means of the word migrare, to depart. ${ }^{24}$ Based on his use of Latin, therefore, it is possible to discern that Eigil conceives of three different forms of movement within the vita-pergere conveys proper movement, vagari unlawful movement, and finally migrare indicates spiritual movement.

Ardo's use of itinerant language in the vita Benedicti Anianensis is much more varied, as he blends what to Eigil were different vocabularies for travel. The most common verbs which Ardo uses to describe any form of travel are ire, to go, and venire, to come. ${ }^{25}$ Beyond these two words, however, he employs a plethora of other verbs to

\footnotetext{
${ }^{22}$ Eigil makes use of the verb pervenio three times throughout the text. See pages 167,173 , and 174.

${ }^{23}$ The verb vagor appears only once on page 183 in the context of Sturmi attempting to eliminate any illicit wandering by constructing a monastery which houses all necessary tools and goods for monastic living.

${ }^{24}$ The verb migrare appears twice within the text, both times in relation to Sturmi's death. See Vita Sturmi, MGH SS 2, 377.

${ }^{25}$ Including compound forms, Ardo uses the verb ire twelve times and venire twenty times within the text. The fact that Ardo describes the arrival of the abbot to various locations more than his setting out is perhaps related to the manner in which uses itinerant narratives more broadly. As I discuss later in this section, travel in the vita Benedicti Anianensis consistently benefits others more than Benedict himself. Hence, it is Benedict's arrival which is important for Ardo to underscore. This contrasts with the vita Sturmi in which Eigil places emphasis on the benefits of travel for Sturmi himself, correspondingly highlighting the departure of the abbot on a journey.
} 
describe journeying including pergere, to go; discedere, to depart; accedere, to approach; circumere, to wander between; and visitare, to visit. ${ }^{26}$ In a single instance where Ardo describes illicit travel, he refers to the monk as a circillionem, a wanderer, who he states was "greedy for property, and an invader of other people's estates."27 By not distinguishing illicit movement with its own vocabulary, I suggest that Ardo does not see travel itself as unlawful, but rather the qualities of individual and the purpose of the journey as definition. ${ }^{28}$ One usage that Ardo does share with Eigil, however, is the exclusive use of the word migrare, to depart, to describe the spiritual movement of an individual after death to God. ${ }^{29}$ Thus, Ardo's use of Latin indicates that he conceives of only two forms of travel, one which is physical and the other spiritual.

We are unable to see whether Radbertus makes lexical distinctions between different forms of travel since he presents no discussion of illicit travel whatsoever within the text. ${ }^{30} \mathrm{He}$ most frequently uses the verb pervenire, to come to, to describe Adalhard's journeys and supplements the use of this verb with venire, to come, and advenire, to

\footnotetext{
${ }^{26}$ Ardo uses pergere six times throughout the text, discedere four times, and accedere, circumere, and visitare three times. Ardo also distinguishes between movement outside of the cloister as a result of a natural disaster through the use of the verb concurrere. This verb occurs twice in the text and in both instances the movement is a reaction to a fire in the cloister. invasorem."

${ }^{27}$ Vita Benedicti Anianensis, chapter 29, col. 372C: "rerumque cupidum et praediis aliorum

${ }^{28}$ Hence, it is acceptable for Ardo to describe Benedict's travels through the verb circumere, despite its relation to the noun circillionem. vita.

${ }^{29}$ Ardo uses the verb migrare to refer to spiritual movement after death eight times throughout the

${ }^{30}$ It is still possible that Radbertus distinguishes between licit and illicit travel, but it is not possible to discern this from the vita Adalhardi as he does not mention unlawful journeying.
} 
arrive. $^{31}$ Thus, Radbertus consistently places emphasis on Adalhard's journeys as arrivals rather than departures. ${ }^{32}$ This is a significant variation from the other two vitae, which sometimes omit mention of a destination or present a monk in mid-journey. Radbertus also makes no distinction in his vocabulary between arrivals of both a physical and spiritual nature. Whereas Eigil and Ardo both use the word migrare to refer specifically to spiritual movement, that particular verb is nowhere to be found within the vita Adalhardi. Instead, Radbertus continues to employ the verbs pervenire and venire to describe spiritual movement after death. ${ }^{33}$ By using the same verbs to denote all forms of movement throughout the text, Radbertus blends their meaning and suggests that he connects all forms of travel together.

The differences in Latinity between the three texts surrounding itinerant language hint at multiple co-existing concepts of monastic travel after 816 . In examining the descriptions of travelling monks, however, these differences are further clarified. Just as there are variances in the language the authors use to depict itinerancy, the reasons behind journeying differ in each of the texts.

The vita Sturmi repeatedly uses journeys as a means to emphasize his changes of status and his progressively more saintly life. It begins with a journey depicting how the future abbot left the house of his parents to travel with the archbishop Boniface across

\footnotetext{
${ }^{31}$ Radbertus makes use of the verb pergere twenty-four times throughout the text. See chapters 1 , $4,5,8,9,11,17,23,48,58,65,70,73,80-83,85$, and 88 . The verb venire does not always refer to movement within the text. Radbertus does refer to it in an itinerant sense ten times throughout the text. See chapters $3,12,17,21,27-28,67,80,86$. He uses the verb advenire four times. See chapters, 12, 29, 79.

${ }^{32}$ The only exception to Radbertus' depiction of Adalhard's journeys as arrivals is when he describes the abbot as fleeing to various locations to escape old visiting friends or family through use of the verb fugere. See chapters 11-13.

${ }^{33}$ Radbertus uses the verb pergere to refer to spiritual journeys seventeen times, and physical journeys seven times. Similarly, he mentions the verb venire five times each for both spiritual and physical journeys.
} 
several Carolingian provinces in order to find a priest who had agreed to care for the young boy. ${ }^{34}$ This trip severs Sturmi from his parents, and underscores his reception by his spiritual kin, Boniface. Eigil links Sturmi's character with that of Boniface by their shared journey. ${ }^{35}$ Introducing Boniface so early in the vita Sturmi serves as a useful tool, as he adds legitimacy to the practice of traveling - though he does so as a bishop, not a monk.

In another trip prompted by Boniface, the first half of the vita involves Sturmi traveling in Bochonia and along the river Fulda, attempting to find a good location for a monastery. ${ }^{36}$ Eigil depicts his search as a quest and test of his endurance. He describes the prolonged peregrination and underscores Sturmi's many failed stops until his eventual endpoint. ${ }^{37}$ Near the end of his quest, Sturmi has a chance meeting with a secular man in a forest:

The man of God asked him who he was and where he came from. The other replied that he was on his way from Wetteran and that the horse he was leading by the halter belonged to his lord Ortis. And so, talking, they passed the night together in that place, for the other man knew the district very well; and when the man of God told him what he had in mind and what he wished to do the other

\footnotetext{
${ }^{34}$ Vita Sturmi, 167.
}

${ }^{35}$ Boniface's own vita depicts a great deal of travel. Although the childhoods of Sturmi and Boniface are not mirror images of one another, Boniface also moves to different monasteries in order to further his spiritual education.

${ }^{36}$ At times, Sturmi travels on his own, while at other times he brings some monks along for the journey. Thus, it is not only the abbot who journeys in this life.

${ }^{37}$ Boniface rejects Sturmi's first potential site on account of it being too near a settlement of pagans. He then travelled for three days up the river Fulda and was again unsuccessful. They also tried a location called Ruohenback, but concluded that Boniface would once again not approve of the site. Sturmi then travels to discuss his failed attempts to find a suitable location with Boniface, who encourages the future abbot by stating, "A place has indeed been prepared in the wilderness, and when Christ wills He will show it to His servants. For this reason continue the search, knowing and believing that you will certainly find it" (chapter 6, 368). Following this chapter, Eigil continues to elaborate on Sturmi's struggle as he continues to search for an indefinite period of time in the next chapter, until finally meeting the secular man in the woods. 
gave him names of the various places and explained where the streams and fountains were to be found. ${ }^{38}$

After having spent the night together, the men go their separate ways and in the subsequent chapter, Sturmi finds the perfect site for his future monastery. The discovery of the location marks a turning point in the text, as Sturmi's long struggle ends and his life as abbot of the monastery of Fulda begins. ${ }^{39}$ Yet, the manner in which Eigil constructs this portion of the vita renders Sturmi's success dependent on the secular man with whom he interacts. ${ }^{40}$ Sturmi is unable to find a suitable site for his monastery alone and not even Boniface knows the proper location. Only through contact with a secular traveler does he manage to procure the information necessary to complete his task. By placing emphasis on this encounter, Eigil highlights both the benefits of traveling in establishing the new monastery, as well as the benefits of contact with the secular community. $^{41}$

Upon finding his perfect location, Sturmi lingered on the site rather than returning directly to his fellow monks. Eigil writes that the abbot "practically spent a whole day

${ }^{38}$ Vita Sturmi, chapter eight, 369: "Cumque eum homo Fei interrogasset, unde veniret; respondit se de Wedereiba venire, domini sui Ortis equum in manu ducere. Colloquentes itaque inter se, ibidem pariter nocte illa manserunt; erat quippe ille homo locorum in solitudine peritissimus. Cumque illi vir Domini quod animo gestabat et quid gereret revelasset, coepit ei locorum nomina indicare, et torrentum et fontium fluenta denuntiare."

${ }^{39}$ Chapters 10-13 describe Sturmi acquiring the land from the emperor and his lords. The monastery is only completely built in chapter 14 . See Vita Sturmi, 369-372.

${ }^{40}$ In her analysis of this search, Raaijmakers ignores this passage which depicts Sturmi conversing with the layman. She writes simply that Sturmi moves deeper and deeper into the forest, which she argues reflects Eigil's desire to construct Fulda as removed from the world. She also writes that it is Sturmi alone who discovers this site, once again emphasizing solitude within the text. In contrast, I suggest that this meeting with the secular man represents a connection which Eigil establishes between the monastery of Fulda and the surrounding community.

${ }^{41}$ Eigil makes it very clear that there is a danger in conversing and even being too near pagans. The secular people I refer to in this instance are members of the Christian laity. See Vita Sturmi, chapters 6 and 7, 368-369. 
wandering (gyrando) over it, exploring its possibilities." ${ }^{, 2}$ The use of the verb gyrare in this instance is somewhat peculiar considering the harsh denunciation of gyrovagues in $R B .^{43}$ At least in this instance, however, Eigil links the concepts of wandering and exploring together and suggests that these practices are acceptable as long as they serve a lawful purpose. Sturmi's wanderings around the site foretells the measured pace of monks inhabiting the future cloister that would be built. The wandering-not aimless, but purposeful-is intended to lay out the sacred boundaries and is thus made legitimate.

Eigil presents one final positive instance of itinerancy after the monks had erected the monastery and established Sturmi as abbot. The community decided to send monks to other monasteries in Rome in order to "become perfectly acquainted with the customs and observances of other brothers." 44 After having spent a year outside of their own cloister, Sturmi and two other monks visit Boniface, who blesses the travelers and confirms the use of foreign Roman customs at Fulda. The abbot, then returns to his own cloister and instructs his monks through his own example, rather than through words. ${ }^{45}$ Sturmi's journey to the Roman monasteries emphasizes two key aspects of his conception of Carolingian monasticism. First, it affirms the author's legitimization of travel as beneficial to both Sturmi and his community at Fulda. Second, it underscores that travel is a fundamental necessity to learning proper monastic customs, as religion was not a matter of books and ideas, but of practices and learned behaviours. Although Eigil

${ }^{42}$ Vita Sturmi, chapter 9, 369: "non modicum diei spatium gyrando et explorando exegisset."

${ }^{43} R B$, chapter $1,170-171$. Eigil states in chapter 14 that Sturmi and his monks had an interest in following RB. See vita Sturmi, 371-372.

${ }^{44}$ Vita Sturmi, chapter 14, 176.

${ }^{45}$ Tbid., 371-372. 
explicitly states that Sturmi enforced $R B$, merely following $R B$ was not sufficient.

Itinerancy was the only means by which Sturmi could learn proper monastic customs. ${ }^{46}$

Whereas Eigil presented Sturmi's conversion to ecclesiastic life as a journey,

Ardo frames Benedict's conversion as a mental shift that occurred while Benedict was

still serving the emperor. He writes, "Benedict continued associating himself in body,

though not in mind, with the activities of the world... In fact still standing in secular habit

he meditated on things which devotion afterwards fulfilled." ${ }^{47}$ Although he later travels

to a monastery, Ardo notes that Benedict had already undergone a spiritual conversion

and chosen life under rule before he entered the cloister. ${ }^{48}$ This characterization and

deemphasizing of the use of travel continues throughout the rest of the vita. At times,

the thought of travel causes the abbot to struggle. ${ }^{49}$

\footnotetext{
${ }^{46}$ This interpretation of learning monastic customs differs from the sources which I explored in the previous chapters. The capitularies enforce regular reading of $R B$ and themselves present a written list of customs for monks to follow. Smaragdus underscores the importance of reading $R B$ by crafting a commentary on the text. Neither source suggests that reading is an inadequate manner of learning proper customs.

${ }^{47}$ Vita Benedicti Anianensis, chapter 5, col. 355D: "tenuit, corpore, non mente se saeculi actibus inserens... Praemeditabat siquidem in saeculari adhuc habitu sistens, quae postea devotus implevit." Ardo also refers to other monk's conversions throughout the vita in non-itinerant manners.

${ }^{48}$ For Benedict's journey to the monastery, see chapter 6 , cols. 356C-356D.

${ }^{49}$ The fact that Benedict struggles with journeying is evident in his very first journey. After being offered the abbacy of his initial community, Ardo writes that Benedict felt his manner of life was too harsh and that he instead "carried his foot (contulit pedem) toward his paternal soil" in order to establish his own monastery on the brook, Aniane (Vita Benedicti Anianensis, chapter 10, cols. 358B-358C). The use of the classical phrase contulit pedem to describe this journey marks the venture as unique within the text and suggests that it was a struggle for Benedict. The fact that Ardo portrays this particular journey as a struggle reinforces the argument that journeying ought to be beneficial to other monks. This rare instance where Benedict moves for his own benefit, to establish a monastery more suited to his way of life, is difficult. For more information on the interpretation of the phrase contulit pedem as a struggle, see Frederick Leverett, et al., A New and Copious Lexicon of the Latin Language (Boston: Wilkins and Carter, 1839), 184. Another indication that Benedict struggled with his highly itinerant role appears when Ardo notes that Benedict did not dread exile, as it would "mentem suam agebat famulari Deo securiorem" (Vita Benedicti Anianensis, chapter 41, col. 372D).
} 
Ardo underscores the positive impact that Benedict's journeying has on other communities. Benedict traveled from his monastery at Aniane to instruct neighbouring communities about Anianese customs. To these communities:

he was like a father, bringing (ferens) assistance and support not only in spiritual matters, but also in material. Often visiting (visitans) them he urged them not to abandon the work they had begun lest the spirit, oppressed by want and worn by terrors, look backward. ${ }^{50}$

Ardo establishes Benedict's role as a provider by highlighting the spiritual and material assistance he brought to neighbouring communities. He repeats this framing of Benedict as a father / provider to other monasteries throughout the text, ${ }^{51}$ foreshadowing his eventual role as head of all monasteries and the paterfamilias of the monastic spiritual family. ${ }^{52}$ Yet, it is significant that Benedict's paternal role is dependent upon him traveling to other monasteries. Rather than simply sending goods or providing assistance through letter correspondence, Ardo depicts Benedict as needing to move physically around the region to deliver aid. ${ }^{53}$ Like Sturmi, we see again emphasized with Benedict that mobility was key to the transmission of Carolingian monastic customs that often take the form of corporal practices and behaviours. For reform to happen, people had by necessity to move from monastery to monastery. Ardo describes how Benedict

\footnotetext{
${ }^{50}$ Vita Benedicti Anianensis, chapter 15, col. 360D: "ipse ut pater erat, subsidium opemque ferens, non spiritualium solummodo rerum, verum et corporalium: quos saepe visitans hortabatur coeptum non deserere opus, ne egestate perculsus terroribusque attritus retro respiceret animus."

${ }^{51}$ Other places Ardo refers to Benedict either as pater or in a superior role due to the assistance he provides are chapter 28 , cols. 366D-367B; chapter 29 , cols. $367 \mathrm{~B}-367 \mathrm{C}$; and chapter 47 , cols. $376 \mathrm{~B}-376 \mathrm{C}$.

${ }^{52}$ Ardo depicts Louis as officially giving Benedict this authority both in chapter 40, cols. 372A$372 \mathrm{~B}$, and chapter 50 , cols. $377 \mathrm{C}-378 \mathrm{~A}$.

${ }^{53}$ Ardo also notes that Benedict had the same role in Louis' court, stating, "Coepit autem post haec vir Dei palatinas terere fores, olimque dimissum ob multorum utilitatem ferre tumultum. Omnes siquidem qui aliorum pressi incommodis imperialia petebant suffragia, cum ad eum accederent." Once again in this passage Benedict's role as provider is dependent upon his travels to the palace. See Vita Benedicti Anianensis, chapter 49, col. 376D.
} 
established the monastery Inde as an exemplary monastic site so that "monks going from other regions might not engage in the noisy conversation to which they were accustomed, but might see the standard and discipline of $R B$ portrayed in usage, walk, and dress of the monks at Inde." ${ }^{54}$ By discouraging the communication of customs at a distance, Ardo implicitly suggests that itinerancy benefits monks as it provides them with the opportunity to learn proper practice through observance.

While Ardo highlights the assistance that Benedict provides to monastic communities through his journeys, he also notes that the abbot performed the same role for the emperor and laymen of the court. He writes:

the man of God began to wear away the palace floors and, for the profit of many, to endure troubles he had one set aside. All who suffered from injuries of others or who sought imperial opinions came to him. He received them with gladness and embraced them... No one, in fact was as compassionate on the wretchedness of the afflicted, no one revealed to the emperor the needs of monks as he did. ${ }^{\mathbf{5 5}}$

The phrase that Ardo uses to describe Benedict's involvement in the emperor's court invokes a sense of constant movement, as it describes the deterioration of the floor under Benedict's perpetual step. Ardo constructs the court as a sort of ceaseless journey for Benedict, and a place where he does not rest, where he suffers, but must endure for the good of others. Not only is Benedict's stay at court depicted as a difficult peregrination like Sturmi's, but it underscores how much time Benedict himself must have remained far from the monastery which he headed.

\footnotetext{
${ }^{54}$ Vita Benedicti Anianensis, chapter 50, col. 377D: "Uniformis mensura in potu, in cibo, in vigiliis, in modulationibus cunctis observanda est tradita. Et quoniam alia per monasteria ut observaretur instituit Regula, suos in Inda degentes ita omni intentione instruxit."

${ }^{55}$ Vita Benedicti Anianensis, chapter 49, 376D-377B: "Coepit autem post haec vir Dei palatinas terere fores, olimque dimissum ob multorum utilitatem ferre tumultum. Omnes siquidem qui aliorum pressi incommodis imperialia petebant suffragia, cum ad eum accederent, alacriter susceptos osculabatur... omnium licet utilitatibus consuleret, monachorum tamen necessitatibus sedulo interveniebat."
} 
Ardo further cements the concept of itinerancy as positive by means of the miracle stories he offers in the text. Of the thirteen miracle stories in the vita, all involve some form of movement or discussion of movement outside the cloister. While in some instances this movement is necessitated by natural disaster, other miracles highlight travel within the narrative. Ardo tells of one instance where:

the venerable father approached them for a visit. Awaiting his arrival, they devoted their energy to procuring an abundant supply of fish and foods, not only out of love for him, but also for all the brothers. There was a meeting of the brothers; fishermen were dispatched; markets were searched. But so much difficulty was involved that nothing could be found for purchase; the fish would not bite... Later it happened that a certain brother was diligently pursuing his effort alongside the river Loire. Suddenly he spied a large fish, one they call a salmon, swimming near the bank. With no hesitation, the brother jumped in to catch it and bring it to the others. There was joy over this, but there was even more wonderment, for they all professed that this came about owing to the merits of venerable Benedict. ${ }^{56}$

While Ardo dwells on the monk's amazement at Benedict's ability to procure the successful capture of an oversized fish, the context in which the miracle takes place emphasizes the importance of itinerancy within the text. This miracle does not respond to some great need or disaster, but rather presents a situation where a community wishes to celebrate Benedict's arrival through a feast. The miracle serves to underscore the desire monks felt for Benedict to visit their communities, and also, like the first example told at the outset of this chapter, the importance for monks to provide suitable hospitality

\footnotetext{
${ }^{56}$ Vita Benedicti Anianensis, chapter 36, cols. 370A-370B: "visitandi gratia Pater venerabilis adisset, quae ibidem acta sint pandam. Siquidem ejus praestolantes adventum, omni studio satagunt, quatenus ejus pro amore copia, piscium ciborumque apparatus non solum illi, verum etiam omnibus fratribus foret abunde. Fit concursus fratrum, sollicitantur piscatores, perscrutantur nundinae: sed tanta evenit difficultas, ut nec ad emendum invenirentur, nec ab eis capi posset, qua de sterilitate nimio afficiebantur moerore... Praeterea accidit ut frater quidam quippiam operis exercens juxta fluvium Ligeris sisteret: et ecce subito praegrandem piscem, quem isicem vocant, conspicit circa littus natantem: ad quem non tardus capiendum insiluit, abstractumque fratribus detulit. Fit quoque hac de re gaudium, sed admiratio major: omnes tamen meritis hoc venerabilis viri Benedicti evenisse confessi sunt."
} 
to guests. ${ }^{57}$ Although Ardo no doubt seeks to honour Benedict by recounting miracles associated with the abbot, the fact that he embeds travel narratives into all the miracle stories imbues itinerancy itself with a form of miraculous quality. Within the vita, journeying encourages miracles to occur.

In the vita Adalhardi, itinerancy again takes on a beneficial role within the text. Radbertus establishes the importance of the contemplative life of Adalhard early in his text and suggests that he was truly cloistered in mind. ${ }^{58}$ Appealing to the reader, he underscores Adalhard's desire to meditate within the monastery, stating, "if he withdrew himself occasionally from such meditation for certain businesses at hand, it was as if going away from the saints he hastened more quickly to return."59 Similarly, his desire for meditation was so strong that Radbertus describes how even at court, although a crowd was making a great deal of noise, "in the midst of them he sat mourning as if he had come there to a contest of weeping. While dwelling there he was thus secretly attending the King of heaven." 60 By emphasizing how Adalhard desired to meditate both in the monastery and at court, Radbertus constructs a sense of similarity between the two places-namely that Adalhard sought to dwell in his mental cloister whether in a sacred or profane space. In both instances, Adalhard seeks to return to meditation when the boisterousness of a crowd or responsibilities of a monk threaten to distract him. Thus,

\footnotetext{
${ }^{57}$ The miracle which I cited at the beginning of this chapter presents a very similar situation as in that instance Benedict's arrival produces an abundance of wine.

${ }^{58}$ Radbertus writes, "His spirit was as the garden of Paradise, enclosed with the wall of faith, planted with all kinds of virtues." See Vita Adalhardi, 37.

${ }^{59}$ Vita Adalhardi, 42.

${ }^{60}$ Vita Adalhardi, chapter 27, col. 1522C: "Itaque ibi residens aliubi coelorum regi secretius assistebat."
} 
Radbertus suggests that within the cloister or outside of it Adalhard was equally burdened by physical action and responsibility. ${ }^{61}$

Within this framework, Radbertus depicts the entire world as similarly tarnishing, and thus physical movement does not mark a movement from one kind of space to another. While physical space might not be differentiated, the degree of interaction Adalhard engaged in was significant. As Adalhard was a cousin to Charlemagne, Radbertus notes that many kinsmen and friends continued to visit the abbot until he finally decided to flee from them to Monte Cassino. He writes:

Thus, fleeing (fugiens) in order to find himself, he came by the strength of the Word to Monte Cassino, not wishing to learn about the country nor to boast about himself. He supposed that he wished only to understand himself and that as long as he stayed within the boundaries of his own country he would not be separated from vices. ${ }^{62}$

In this instance, movement benefits the abbot by providing a means by which he might gain solitude and anonymity. Radbertus notes that Adalhard "became more distinguished in poverty, more brilliant in flight, more sublime in humble wretchedness" by his retreat. ${ }^{63}$ Although the abbot is eventually found and brought back to his former monastery, Radbertus underscores the inevitable need to retreat from human society.

${ }^{61}$ While Radbertus presents a similar interest in the contemplative life as Smaragdus of Saint Mihiel, whose work I examine in the previous chapter, the manner in which they interpret itinerancy varies. Whereas Smaragdus' involvement with interiority renders him somewhat indifferent to itinerancy, Radbertus suggests that any involvement with the physical world hinders a monk, be it within the monastery or without.

${ }^{62}$ Vita Adalhardi, chapter 11, col. 1514D: "Itaque sic se fugiens ut se inveniret, pervenit secum in fortitudine verbi usque ad montem Casinum, nolens patriae cognoscere curas, neque praedicari de se vento jactantiae laudes. Cogitabat autem solum se velle tantum percepisse, necdum divisum a vitiis, quousque moraretur infra patriae fines."

${ }^{63}$ Vita Adalhardi, chapter 13, col. 1515D: "Sed sui contemptor eximius paupertate fit ornatior, fuga clarior, vilitate humilitatis sublimior." 
All of these authors include narratives of travel outside the cloister within their vitae and by them show a multiplicity of benefits and purposes for it. Eigil and Radbertus indicate that travel had the potential to benefit a monk by being both spiritually edifying and providing an opportunity for him to disconnect from his previous life. Ardo and Eigil demonstrates a particularly favourable attitude toward itinerancy by noting that travel was necessary to transmit spiritual exercises and monastic customs, as well as being a vehicle for miracles to occur.

\section{CONCLUSION}

Unlike other monastic writing from the time of the Aachen reform councils which encourages monks to practice the reception of guests above the pursuit of traveling themselves, each of the vitae which I examine in this chapter emphasizes the benefits of monastic itinerancy. They depict an array of monks and abbots moving beyond the walls of their own cloisters in order to visit both sacred and secular places and do not suggest that this movement is harmful to the travelers. This representation particularly clashes with the capitulary texts from Aachen which attempt to establish the monastic role largely through the physical occupation of the cloister. Rather than threatening the claustration of a monk, however, the authors of the vitae often advocate that itinerancy has the ability to benefit a monk. Although it is important to emphasize the fact that these vitae all encourage itinerancy, it is even more significant to note the fluidity that surrounds the manner in which they conceive of and describe travel. Each text presents distinct language to describe movement through uncloistered space and suggests that it serves very different purposes. 


\section{CONCLUSION}

Just as the Plan of Saint Gall portrays the monastery as a hub for interaction between monks and outsiders, accounts of worldly contact saturate ninth-century monastic writing. The Aachen capitulary texts lay out provisions for the proper reception of guests within the cloister, ${ }^{1}$ and Smaragdus emphasizes that "hospitality must be pursued" and encourages monks to conceive of their way of life as an inward journey to God. $^{2}$ Hagiographic sources highlight itinerancy by suggesting the spiritual and educational benefits of journeying, as well as illustrating the abundance of miracles which take place while travelling. ${ }^{3}$ All of these representations of contact, show that it did not merely serve the functional purpose of obtaining basic requirements. Rather, authors incorporated interaction as a central component of monastic life in a multitude of distinct monastic programs.

The Aachen capitulary texts and the Plan of Saint Gall demonstrate that monks had a desire to put up physical walls around cloisters within the architecture of Carolingian monasteries. These cloistered areas served as boundaries between the sacred and secular worlds and heightened the sense of transition between spaces. Yet, both texts also underscore that this boundary was not impenetrable - they anticipated that guests would enter the cloister and monks would depart. Thus, the current historiographic

\footnotetext{
${ }^{1}$ Primae decreta, CCM 1, chapter 25, 464-465.

${ }^{2}$ Smaragdus, Expositio, chapter 53, 279.

${ }^{3}$ See chapter $4,93-103$.
} 
assertion that interaction threatened claustration by bringing monks into contact with the world is shown to be problematic. While claustration does refer to a monk's primary residence within a cloister, it does not require a constant presence within a monastery. In particular, Smaragdus emphasizes that claustration is also more importantly an interior mental state which remains with a monk no matter where his physical body resided. Cloisters assist monks in concentrating on the opus Dei, but they do not in themselves ensure proper monastic claustration. Precisely what this interior form of claustration involved and how Carolingian monks learned to practice it is an avenue for future scholarship.

By exploring the variety of approaches monastic authors took toward presenting and encouraging interaction, this study challenges the depiction of Carolingian monasticism as homogeneous. Although contact with the outside world is only one aspect of monastic life, the divergences in the customs and conceptions surrounding interaction within these texts mirror the fluidity of monastic practices and programs across the empire. The Aachen capitularies of $816 / 817$, though they remain a useful monastic source, did not have as profound an impact on monastic thought as current scholarship suggests. 


\section{BIBLIOGRAPHY}

\section{PRIMARY SOURCES}

Admonitio generalis. Ed. A. Boretius, 52-62. MGH Cap. I. Hanover, 1883.

Annales regni Francorum. Ed. F. Kurze. MGH SS, SRG 6. Hanover, 1895.

Ardo of Aniane. Vita sancti Benedicti Anianensis. Ed. J.-P. Migne, cols. 0351B-0384C. PL 103. 1881.

Benedict of Aniane. Concordia Regularum. Ed. Pierre Bonnerue. 2 vols. CCCM 168. Turnhout, 1999.

Capitulare missorum generale 802. Eds. Alfred Boretius and Victor Krause. MGH Cap. 1, ed. Alfred Boretius (Hanover, 1883).

Capitularia regum Francorum. Eds. Alfred Boretius and Victor Krause. MGH Cap. 1-2. Hanover, 1883.

Capitula tractanda cum comitibus episcopis et abbatibus. Eds. Alfred Boretius and Victor Krause, 161-162. MGH Cap. 1. Hanover, 1883.

Chronicon Sancti Michaelis. Ed. Ludovicus Tross. Hammone, 1857.

Die Briefen des heiligen Bonifatius and Lullus. Ed. Michael Tangl. MGH ES I. Berlin, 1916.

Eigil. Vita sancti Sturmi. Ed. George Pertz, 365-377. MGH SS II. Hanover, 1829.

Ermoldus Nigellus. Carmen in Honorem Hludowici. Ed. Ernest Dummler. MGH Poetae latini aevi Carolini, vol. 2, 1-91. Hanover, 1884.

Notitia de servitio monasteriorum. Ed. Josef Semmler, 483-491. CCM 1. Sieburg: Franz Schmitt, 1963.

Paschasius Radbertus. Vita sancti Adalhardi. Ed. J.P. Migne. PL 120: 1507-1556. 
Plan of Saint Gall. St. Gall Monastery Plan. http://www.stgallplan.org/index.html (Accessed August 10, 2009).

Regula sancti Benedicti. In RB 1980. Ed. Timothy Fry. Collegeville: Liturgical Press, 1981.

Regula sancti Benedicti abbatis Anianensis sive collection capitularis. Ed. Josef

Semmler, 501-536. CCM 1. Sieburg: Franz Schmitt, 1963.

Smaragdus of Saint-Mihiel. Via Regia. Ed. J.-P. Migne, cols 13C-552D. PL 102, 1974.

—. Diadema monachorum. Ed. J.-P. Migne, cols. 593B-690A. PL 102, 1974.

—. Expositio in regulam sancti Benedicti. Ed. J.-P. Migne, cols. 689A-932C. PL 102, 1974.

Statuta Murbacensia. Ed. Josef Semmler, 437-450. CCM 1. Sieburg, 1963.

Synodi primae Aquisgranensis acta praeliminaria. Ed. Josef Semmer, 433-436. CCM 1. Sieburg: 1963.

Synodi primae Aquisgranensis decreta authentica 816. Ed. Josef Semmler, 451-468. CCM 1. Sieburg: Franz Schmitt, 1963.

Synodi secundae Aquisgranensis decreta authentica 817. Ed. Josef Semmler, 469-481. CCM 1. Sieburg: Franz Schmitt, 1963.

\section{SECONDARY SOURCES}

Airlie, S. "The palace of memory: the Carolingian court as political centre." In Courts and Regions in Medieval Europe. Eds. S. Rees Jones, R. Marks and A. Minnis, 120. York: York Medieval Press, 2000.

_- "Bonds of power and bonds of association in the court circle of Louis the Pious." In Charlemagne's Heir. Eds. Godman and Collins, 191-204. Oxford: Oxford University Press, 1990.

Althoff, Gerd. Family, Friends and Followers: Political and Social Bonds in Medieval Europe. Cambridge: Cambridge University Press, 2004. 
Amann, Emile. L'époque Carolingienne. Paris: Bloud \& Gay, 1947.

Auzias, L. L'Aquitaine carolingienne. Bibliothèque Méridionale. Paris: 1937.

Bischoff, B. "Muridac docissimus plebis, ein irischer Grammatiker des XI. Jarhunderts." Celtica 5 (1960): 40-44.

Barry, David, trans. Commentary on the Rule of Saint Benedict. Kalamazoo: Cistercian Publications, 2007.

Bernhardt, John W. Itinerant Kingship and Royal Monasteries in Early Medieval Germany. Cambridge: Cambridge University Press, 1993.

Booker, Courtney. Past Convictions: The Penance of Louis the Pious and the Decline of the Carolingians. Philadelphia: University of Pennsylvania Press, 2009.

Bovendeert, Jasmijn. "Royal or Monastic Identity? Smaragdus' Via Regia and Diadema Monachorum Reconsidered." In Texts and Identities in the Early Middle Ages. Ed. Richard Corradini, 239-251. Vienna: Verlag, 2006.

Brown, Giles. "The Carolingian Renaissance." In Carolingian Culture: Emulation and Innovation. Ed. Rosamond McKitterick, 1-51. Cambridge: Cambridge University Press, 1994.

Brunterch, J. P. "Moines bénédictine et chanoines réformés au secours de Louis le Pieux." Bulletin de la société nationale des antiquaires de France (1986-87): 7085.

Bullough, D.A. "Roman Books and Carolingian renovatio." In Carolingian Renewal: Sources and Heritage, 1-38. Manchester: Manchester University Press, 1991.

- "Aula renovate: the Carolingian court before the Aachen palace." Carolingian Renewal: Sources and Heritage, 267-301. Manchester: Manchester University Press, 1991.

- . "Euopae Pater: Charlemagne and his Achievement in the Light of Recent Scholarship.” English Historical Review 75 (1970): 59-105.

Cabaniss, Allen, trans. Benedict of Aniane: The Emperor's Monk. Kalamazoo: Cistercian Publications, 2008.

—. Charlemagne's Cousins. Syracuse: Syracuse University Press, 1967. 
Caner, Daniel. Wandering, Begging Monks: Spiritual Authority and the Promotion of Monasticism in Late Antiquity. Los Angeles: University of California Press, 2002.

Cassidy-Welch, Megan. Monastic Spaces and their Meanings. Turnhout: Brepols, 2001.

Certeau, Michel de, and Steven Rendall, trans. The Practices of Everyday Life. Berkeley: University of California Press, 1984.

Chélini, Jean. L'Aube du Moyen Âge, naissance de la chrétienté occidentale : la vie religieuse des laïcs dans l'Europe carolingienne (750-900). Paris: Picard, 1991.

Claussen, M.A. The Reform of the Frankish Church. Cambridge: Cambridge University Press, 2004.

Clercq, Carlo de. La Législation religieuse franque de Clovis à Charlemagne. Étude sur les actes de conciles et les capitulaires, les statuts diocésains et les règles monastiques, 507-814. Leuven: Bureau du recueil, 1936.

- Neuf capitulaires de Charlemagne concernant son oeuvre réformatrice par les "Missi" : texte critique et traduction. Milan: Giuffrè, 1968.

Cochelin, Isabelle. "Evolution des coutumiers monastiques dessinée à partir de l'étude de Bernard." In From Dead of Night to End of Day. Eds. Susan Boynton and Isabelle Cochelin, 29-66. Turnhout: Brepols, 2006.

- . "Community and Customs. Obedience or Agency?" In Obaedientia. Formen und Grenzen von Macht und Unterordnung im mittlealterlichen Religiosentum. Eds. Sébastien Barret and Gert Melville, 229-253. Munich: Lit Verlag, 2005.

Cohen, A.P. The Symbolic Construction of Community. Sussex: Ellis Horwood Limited, 1985.

Collins, Roger. Charlemagne. London: Palgrave, 1998.

Constable, Giles. "The Realities of Reform: (2) Monastic Activities and Relations with Secular Society." In Reformation of the Twelfth Century, 209-256. Cambridge: Cambridge University Press, 1998.

- "The Ceremonies and Symbols of Entering Religious Life and Taking the Monastic Habit, from the Fourth to the Twelfth Century." Segni e riti nella chiesa altomedievale occidentale 2 (1987): 771-834. 
—. Religious Life and Thought. London: Variorum Reprints, 1979.

-. "Monks and Canons in Carolingian Gaul." In After Rome's Fall. Ed. Alexander Murray, 320-336. Toronto: University of Toronto Press, 1998.

Cubitt, C. Anglo-Saxon Church Councils, c. 650-c. 850. London: Leicester University Press, 1995.

Diem, Albrecht. "Monks, Kings, and the Transformation of Sanctity: Jonas of Bobbio and the End of the Holy Man," Speculum 82 (2007): 521-559.

Dietz, Maribel. Wandering Monks, Virgins, and Pilgrims: Ascetic Travel in the Mediterranean World, A.D. 300-800. Pennsylvania: Pennsylvania State University Press, 2005.

Donnat, L. "Les coutumiers du Moyen Age et la Règle de Saint Benoît." In Regulae Benedicti Studia. Annuarium Internationale 16 (1989): 37-56.

Dubreucq, Alain. "Smaragde de Saint-Mihiel et son temps : enseignement et bibliothèques à l'époque carolingienne." Mélanges de la Sorbonne 7 (1986): 7-36.

Dumas, A., "La parole et l'écriture dans les capitulaires carolingiens." In Mélanges d'histore du moyen âge dédiés â la mémoire de Louis Halphen, 209-216. Paris: Presses universitaires de France, 1951.

Emerton, Ephraim, trans. The Letters of Saint Boniface. Ed. Thomas Noble. New York: Columbia University Press, 2000.

Ewig, Eugene. "Saint Chrodegang et la réforme de l'élise franque." In Spätantikes und fränkisches Gallien, 232-259. Munich: Thorbecke, 1979.

Firey, Abigail. "The Collectio Dionysiana." Carolingian Canon Law Project. http://www.rch.uky.edu/CCL/article-dionysiana.html (Accessed Jan. 25, 2009).

Fouracre, Paul. "The Origins of the Carolingian Attempt to Regulate the Cult of the Saints." In The Cult of Saints in Late Antiquity and the Early Middle Ages. Eds. James Howard-Johnston and Paul Hayward, 143-165. Oxford: Oxford University Press, 1999.

Frassetto, Michael ed. Medieval Purity and Piety: Essays on Medieval Clerical Celibacy and Religious Reform. New York: Garland Publishers, 1998. 
Freeman, A., "Carolingian Orthodoxy and the Fate of the Libri Carolini." Viator 16 (1985): 65-108.

—. "Theodulf of Orleans and the Libri Carolini." Sepculum 32 (1957): 663-705.

Fros, Henri. "Liste des translations et inventions de l'époque carolingienne." Analecta Bollandiana 104 (1986) : 427-429.

Gaillard, Michèle. D'une réforme à l'autre (816-934): Les communautés religieuses en Lorraine à l'époque Carolingienne. Paris: Sorbonne, 2006.

Ganshof, F.L. Frankish Institutions Under Charlemagne. Trans. Bryce Lyon and Mary Lyon. Providence: Brown University Press, 1968.

—. Recherches sur les capitulaires. Paris: Sirey, 1958.

—. "Louis the Pious Reconsidered." History 42 (1957): 171-180.

Ganz, David. "The Lives of Adalhard and Wala: Quotations in Corbie Biography." In Corbie in the Carolingian Renaissance, 82-92. Sigmaringen: Jan Thorbecke, 1990.

Geary, Patrick J. Before France and Germany: the Creation and Transformation of the Merovingian World. New York: Oxford University Press, 1988.

Godman, Peter, and Roger Collins, ed. Charlemagne's Heir. Oxford: University of Oxford Press, 1990.

Godman, P. Poets and Emperors: Frankish Politics and Carolingian Poetry. Oxford: University of Oxford Press, 1987.

- Poetry of the Carolingian Renaissance. Norman: University of Oklahoma Press, 1985.

George, Philippe. "L'hospitalité, la charité et le soin aux malades à Stavelot-Malmédy au Moyen Age VII-XII siècles." Revue bénédictine 108 (1998): 315-330.

Grabowsky, Annette, and Clemens Radl. "The Second Benedict." In Benedict of Aniane: The Emperor's Monk, 1-26. Kalamazoo: Cistercian Publications, 2008.

Halphen, L. "L'idée de l'Etat sous les Carolingiens." Revue historique 185 (1939): 62-67. 
Hartmann, Wilfried. "Das Zeitalter Ludwigs des Frommen." In Die Synoden der Karolingerzeit im Frankenreich und in Italien. Paderborn: Schöningh, 1989.

Head, Thomas. "The Early Medieval Trasformation of Piety." In The Long Morning of Medieval Europe. New Directions in Early Medieval Studies. Eds. Jennifer R. Davis and Michael McCormick, 156-160. Burlington: Ashgate, 2008.

Hen, Y. The Royal Patronage of Liturgy in Frankish Gaul to the Death of Charles the Bald (877). London: Boydell Press, 2001.

Hildebrandt, M.M. The External School in Carolingian Society. Leiden: E.J. Brill, 1992.

Hill, Joyce. "Aelfric and Smaragdus." Anglo-Saxon England 21 (1992): 203-237.

Holtz, Louis, Adele Kibre, and B. Löfstedt. "Les origines méridonionales de Smaragde." Liber in partibus Donati. Vol. 68 of CCCM, 1986.

Horn, Walter. "On the Origins of the Medieval Cloister." Gesta 12, no. 1 (1973): 13-52.

Horn, Walter and Ernest Born. The Plan of Saint Gall. Berkeley: University of California Press, 1979.

Innes, Matthew. "Charlemagne's Government." In Charlemagne: Empire and Society. Ed. Joanna Story, 71-89. Manchester: Manchester University Press, 2005.

- . "Kings, monks and patrons: political identities at the abbey of Lorsch," in $\mathrm{La}$ royauté et les élites dans l'Europe carolingienne. Ed. Regine Le Jan, 301-324. Lille: Centre d'Histoire de l'Europe du Nord-Ouest, 1997.

- "Memory, orality and literacy in an early medieval society." Past and Present 158 (1998): 3-36.

Jestice, Phyllis G. Wayward Monks and the Religious Revolution of the Eleventh Century. Boston: Brill, 1997.

Jong, Mayke de. "Charlemagne's Church." In Charlemagne: Empire and Society. Ed. Joanna Story, 103-135. Manchester: University of Manchester Press, 2005.

- "Imitatio Morum. The Cloister and Clerical Purity in the Carolingian World." In Medieval Purity and Piety. Ed. Michael Frassetto, 49-80. New York: Garland Publishing, 1998. 
_. In Samuel's Image. New York: E.J. Brill, 1996.

- "Carolingian Monasticism: The Power of Prayer." In vol. 2 of New Cambridge Medieval History II, c. 700-900. Ed. Rosamond McKitterick, 622-653.

Cambridge: Cambridge University Press, 1995.

- "Growing up in a Carolingian Monastery: Magister Hildemar and his Oblates." Journal of Medieval History 9 (1983): 99-128.

Kantorowicz, Ernst. The King's Two Bodies: A Study in Medieval Political Theology. Princeton: Princeton University Press, 1957.

Kardong, Terrence. "'If you have clasped hands, rouse your neighbor!' Smaragdus' Comments on Benedict's Chapter Concerning the Abbatial Office." American Benedictine Review 58, no. 3 (2007): 239-248.

- "Smaragdus and his Work." In Commentary on the Rule of Saint Benedict. Trans. David Barry, 1-7. Kalamazoo: Cistercian Publications, 2007.

- "The Earliest Commentator on RB: Smaragdus on Benedict's Prologue," American Benedictine Review 55, no. 2 (2004): 171-193.

Kasten, Brigitte. Adalhard von Corbie: Die Biographie eines karolingischen Politikers und Klostervorstehers. Düsseldorf: Droste, 1986.

Kelly, Michael. "Reflections on the Significance of Stabilitas and Conversatio Morum in Benedictine Commitment." The American Benedictine Review 55, no. 3 (2004): 251-259.

Kemp, Eric Waldram. Canonization and Authority in the Western Church. London: Oxford University Press, 1948.

Kibre, Adele. Prolegomena to the Unpublished Texts of Smaragdus' Commentary on Donatus, 'De partibus orationis'. Chicago, 1930.

King, P.D. Charlemagne: Translated Sources. Kendel: P.D. King, 1987.

Kleinclausz, Arthur. L'Empire carolingien, ses origines et ses transformations. Paris: Hachette, 1902. 
Laistner, Max L.W. "The Date and Recipient of Smaragdus' 'Via regia'." Speculum 3 (1928): 41-44.

Leclercq, Jean. "The Relevance of Smaragdus to Modern Monasticism." In Commentary on the Rule of Saint Benedict. Trans. David Barry, 25-34. Kalamazoo: Cistercian Publications, 2007.

- . "Smaragdus." In An Introduction to the Medieval Mystics of Europe. Ed. Paul E. Szarmach, 37-52. Albany: State University of New York Press, 1984.

_. "La stabilité selon la Règle de saint Benoît." Collectanea Cisterciensia 37 (1975): 197-204.

- The Love of Learning and the Desire for God. Trans. Catherine Misrahi. New York: Fordham University Press, 1960.

—. La voie royale. La diadème des moines. Vauban: La-Pierre-qui-vivre, 1949.

—_. "Smaragdus et la grammaire chretienne." Revue du Moyen Age 4 (1948): 15-22.

Lesne, E. "L'économie domestique d'un monastère au IXe siècle d'après les status d'Adalhard de Corbie." In Mélanges d'historie du Moyen Age offerts à $M$. Ferdinand Lot par ses amis et ses élèves, 385-420. Paris: Edouard Champion, 1925.

_. "Les ordonnances de Louis le Pieux." Revue d'histoire de l'Eglise de France 6 (1920): 161-175, 321-338 and 449-488.

Lifshitz, Felice. The Name of the Saint. The Martyrology of Jerome and Access to the Sacred in Francia, 627-827. Notre Dame: University of Notre Dame, 2006.

Mayvaert, Paul. "The Medieval Monastic Claustrum." Gesta 12, no. 1 (1973): 53-59.

McKitterick, Rosamond. "The Illusion of Royal Power." The English Historical Review 115 , no. 460 (2000): 1-20.

- "Knowledge of Canon Law in the Frankish Kingdom before 789: the Manuscript Evidence." Journal of Theological Studies 36 (1985): 97-117. 
- The Frankish Kingdoms under the Carolingians, 751-987. London: Royal Historical Society, 1977.

McKitterick, Rosamond, ed. Carolingian Culture: Emulation and Innovation. Cambridge: Cambridge University Press, 1994.

McMurray, James. "Monastic Stability." Cistercian Studies 1 (1966): 209-224.

Miquel, Pierre. "De la stabilité." Collectanea Cisterciensia 36 (1974): 313-322.

Morant, Roland W. The Monastic Gatehouse. Chippenham: Antony Rowe, 1995.

Mullinger, J. Bass. The Schools of Charles the Great and the Restoration of Education in the Ninth Century. New York: Stechert, 1877.

Nelson, Janet L. "Legislation and Consensus in the Reign of Charles the Bald." In Ideal and Reality. Edited by P. Wormald, 29-48. Oxford: Oxford University Press, 1983.

- "The Voice of Charlemagne." In Belief and Culture: Studies in the Middle Ages. Edited by R. Gameson and H. Leyser, 76-78. Oxford: Oxford University Press, 2001.

Noble, Thomas, and Thomas Head, eds. Soldiers of Christ: Saints and Saint's Lives from Late Antiquity and the Early Middle Ages. University Park: Pennsylvania State University Press, 1995.

Noble, Thomas. "The Republic and the Franks." In The Republic of St. Peter, 277-324. Philadelphia: University of Pennsylvania Press, 1984.

—_ "Louis the Pious and His Piety Re-reconsidered." Revue belge 58 (1980): 297316.

- "The Monastic Ideal as a Model for Empire: The Case of Louis the Pious." Revue bénédictine 86 (1976): 235-50.

Palmer, James. "The 'vigorous rule' of Bishop Lull: between Bonifatian mission and Carolingian Church Control.” Early Medieval Europe 13, no. 3 (2005): 249-276.

Peltier, H. "Smaragde." In Dictionnaire de théologie catholique, col. 2246-2250. Paris: Letouzey, 1959. 
Ponesse, M.D. "Smaragdus of St Mihiel and the Carolingian Monastic Reform." Revue bénédictine 116 (2006): 367-392.

- "Learning in the Carolingian Court and Cloister: Compilation and Innovation in the writings of Smaragdus of St Mihiel." Ph.D. diss., University of Toronto, 2005.

Pössel, Christina. "Authors and Recipients of Carolingian Capitularies, 779-829." In Texts and Identities in the Early Middle Ages. Ed. Richard Corradini, 253-275. Vienna: Akademie der Wissenschaften, 2006.

Raaijmakers, Janneke. "Sacred Time, Sacred Space. History and Identity at the Monastery of Fulda (744-856)." PhD Diss., University of Amsterdam, 2003.

Rabe, Susan A. "The mind's eye: theological controversy and religious architecture in the reign of Charlemagne." In Medieval liturgy: a book of essays. Ed. Lizette LarsonMiller, 235-266. New York: Garland Publishing, 1997.

Rädle, Fidel. Studien zu Smaragd von Saint-Mihiel. Munich: Wilhelm Fink Verlag, 1974.

Reuter, T. 1992. The Annals of Fulda, Ninth-Century Histories 2, Manchester (1985, 1990).

- "The end of Carolingian expansion." In Charlemagne's Heir. Eds. Godman and Collins, 391-405. Oxford: University of Oxford Press, 1990.

Riché, Pierre. The Carolingians: A Family who Forged Europe. Trans. Michael Allen. Philadelphia: University of Pennsylvania Press, 1993.

Rosenwein, Barbara, ed. Negotiating Space. Power, Restraint, and Privileges of Immunity in Early Medieval Europe. Manchester: Manchester University Press, 1999.

Rosenwein, Barbara, Thomas Head, and Sharon Farmer. "Monks and their Enemies: A Comparative Approach,” Speculum 66, no. 4 (1991): 764-796.

Schmitz, Gerhard. "The Capitulary Legislation of Louis the Pious." In Charlemagne's Heir. Eds. Peter Godman and Roger Collins, 425-436. Oxford: University of Oxford Press, 1991).

Schmitz, Philibert. "L'influence de St. Benoît d'Aniane dans l'histoire de l'ordre de St. Benoît." In Il monachesimo Nell 'Alto Medieovo e la Formazione Della Civilta Occidental, 401-415. Spoleto: Fondazione CISAM, 1957. 
Schroll, Mary Alfred. Benedictine Monasticism as Reflected in the Warnefrid-Hildemar Commentaries on the Rule. New York: Ams Press, 1967.

Semmler, Josef. "Réforme bénédictine et privilège impérial." In Naissance et fonctionnement des réseaux monastiques et canoniaux, 21-32. Saint-Etienne: Publications Université Jean Monnet, 1991.

- "The end of Carolingian expansion." In Charlemagne's Heir. Eds. Peter Godman and Roger Collins, 391-405. Oxford: University of Oxford Press, 1990.

- "Benedictus II : una regula - una consuetudo." In Benedictine culture 7501050. Ed. W. D. Verhelst Lourdeau, 1-49. Leuven: Leuven University Press, 1983.

—. "Introductio." In Consuetudines corbeienses, CCM 1. Ed. K. Hallinger. Sieburg: F. Schmitt, 1963.

- . "Karl der Große und das fränkische Mönchtum." In Karl der Große: Lebenswerk und Nachleben. Ed. Wolfgang Braunfels, 255-289. Düsseldorf: Schwann, 1965.

Semmler, Josef, and A.E. Verhulst. "Les statuts d'Adalhard de Corbie de l'an 822." Le Moyen Age 17, no. 4 (1962): 91-122 and 233-269.

Smith, Julia M.H. "The Problem of Female Sanctity in Carolingian Europe c. 780-920." Past and Present 146 (1995): 3-37.

Souter, A. "Contributions to the Criticism of Zmaragdus's Expositio Libri Comitis." Journal of Theological Studies 9 (1908): 584-597.

—. "Further Contributions to the Criticism of Zmaragdus's Expositio Libri Comitis." Journal of Theological Studies 23 (1922): 73-76.

- "A Further Contribution to the Criticism of Zmaragdus's Expositio Libri Comitis." Journal of Theological Studies 34 (1933): 46-47.

Story, Joanna. Charlemagne: Empire and Society. Manchester: Manchester University Press, 2005.

Sullivan, Richard. "The Carolingian Age: Reflections on its Place in the History of the Middle Ages." Speculum 64 (1989): 267-306. 
_. "What Was Carolingian Monasticism? The Plan of St Gall and the History of Monasticism." In After Rome's Fall. Ed. Alexander Murray, 251-287. Toronto: University of Toronto Press, 1998.

Theuws, F., Mayke de Jong, and Carine van Rhijn, eds. Topographies of Power in the Early Middle Ages. Leiden: Brill, 2001.

Ullmann, Walter. The Church and the Law in the Earlier Middle Ages. London: Varior Reprints, 1975.

Van Engen, John. "The 'Crisis of Cenobitism' Reconsidered: Benedictine Monasticism in the Years 1050-1150." Speculum 61, no. 2 (April 1986): 269-304.

Vogüé, Adalbert de. "The Cenobitic Rules of the West." Monastic Studies 12 (1977): 175-183.

—. La communauté et l'abbé dans la règle de saint Benoît. Bruges: Desclée de Brouwer, 1961.

Wallace-Hadrill, J.M. The Frankish Church. Oxford: Oxford University Press, 1983.

Wilmart, A. "Smaragde et le Psautier." Revue Bénédictine 31 (1922): 350-360.

Wood, Ian. "The Missionary Life." In Cult of Saints in Late Antiquity and the Middle Ages. Eds. James Howard-Johnston and Paul Hayward, 167-183. Oxford: Oxford University Press, 1999.

- "Missionary Hagiography in the Eighth and Ninth Centuries." In Ethnogenese und Überlieferung. Eds. Karl Brunner and Brigitte Merta. Munich: R. Oldenbourg, 1994.

Zola, Alan. "Radbertus' Monastic Voice: Ideas about Monasticism at Ninth-Century Corbie.” PhD Diss., Loyola University, 2008. 